UNIVERSIDADE DE SÃO PAULO

FACULDADE DE FILOSOFIA, LETRAS E CIÊNCIAS HUMANAS

DEPARTAMENTO DE FILOSOFIA

PROGRAMA DE PÓS-GRADUAÇÃO EM FILOSOFIA

Frederico Lopes de Oliveira Diehl

Lei de natureza e lei civil em Hobbes 
Frederico Lopes de Oliveira Diehl

\section{Lei de natureza e lei civil em Hobbes}

Dissertação apresentada ao programa de Pós-Graduação em Filosofia do Departamento de Filosofia da Faculdade de Filosofia, Letras e Ciências Humanas da Universidade de São Paulo, para obtenção do título de Mestre em Filosofia, sob a orientação do Prof. Dr. Alberto Ribeiro Gonçalves de Barros.

São Paulo 


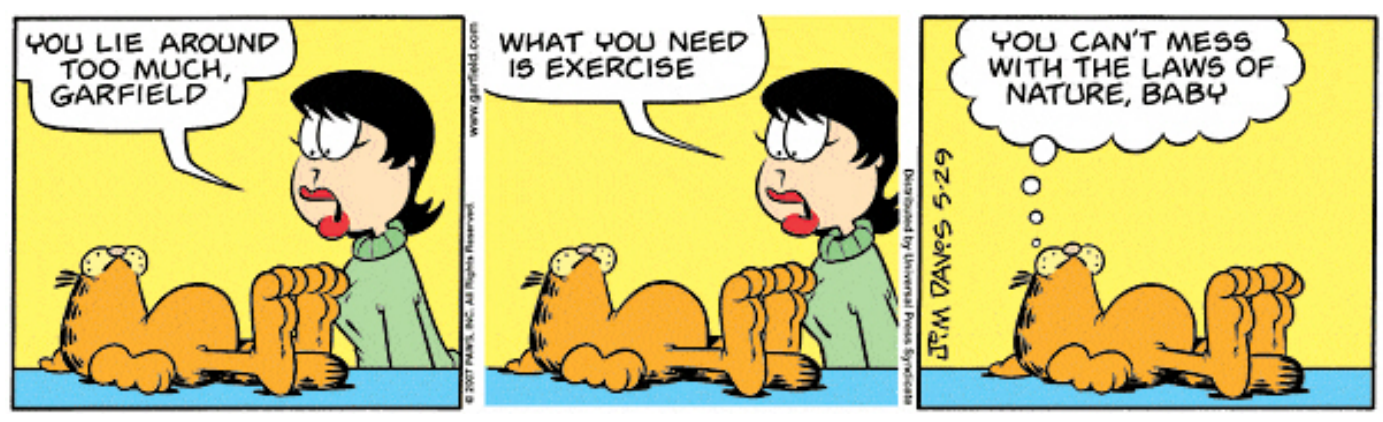




\section{Agradecimentos institucionais}

À Secretaria do Departamento de Filosofia da FFLCH/USP, nas pessoas de Maria Helena, Marie e Verônica, por evitarem meu jubilamento nas quatro vezes em que esqueci de fazer matrícula.

À CAPES, pela concessão da bolsa de estudos.

Ao Centro de Estudos Norberto Bobbio, pelo apoio.

\section{Agradecimentos acadêmicos}

Ao Alberto, pela orientação.

Aos examinadores da banca de qualificação, Maria das Graças e José Reinaldo, pelas críticas e sugestões.

Ao Sérgio Cardoso, por presidir a banca de defesa.

Aos colegas dos Cadernos de Ética e Filosofia Política, aos colegas dos grupos de pesquisa sobre filosofia política romana e sobre filosofia do século XVII do projeto temático Natureza e História e aos colegas dos grupos de pesquisa sobre democracia e sobre direitos humanos do Centro de Estudos Norberto Bobbio.

Ao Guilherme Rafare, ao João Paulo Lovo, à Maria Fernanda Rocha Barros e ao Samuel Barbosa, pela ajuda na aquisição de bibliografia.

Aos amigos Adilson Tavares, André Fávero, Benjamin J. Messelman, Bruno Pinho, Cláudia Perrone-Moisés, Fábio Alface Alves Moura, Guilherme Assis de Almeida, Guilherme Rafare, Guilherme Teixeira, Isadora Prévide, Luis César Oliva, Marcelo Gross Vilanova, Maria Cecília Pedreira de Almeida, Marília Côrtes de Ferraz, Patrícia Aranovich, Renata Nagamine, Roberto Bolzani, Rodrigo Ribeiro de Souza, Samuel Barbosa e Valdemar Bragheto Junqueira, pelas críticas, sugestões e auxílios diversos.

Aos amigos Daniel Antiquera, Emerson Fabiani, João Paulo Lovo, Marco Antonio F. Berbel e Newton Gomes Pereira, pela leitura detida e análise minuciosa do texto. 


\section{RESUMO}

DIEHL, Frederico. Lei de natureza e lei civil em Hobbes. 2009. 205 f. Dissertação de Mestrado - Faculdade de Filosofia, Letras e Ciências Humanas. Departamento de Filosofia, Universidade de São Paulo, São Paulo, 2009.

Dentre os debates a respeito da filosofia política de Hobbes, as relações entre lei de natureza e lei civil são objeto de grande controvérsia. Principalmente dois pontos são discutidos em relação à lei de natureza. $\mathrm{O}$ primeiro corresponde à sua imperatividade: a lei de natureza tem força de comando no estado de natureza ou é mera recomendação? O segundo corresponde à sua relação com a lei civil: são ambas a mesma coisa, são contrárias, são complementares? Com vistas a responder a esses questionamentos, a presente dissertação investiga três utilizações do conceito de lei de natureza por Hobbes - como preceito da razão, como comando de Deus e como lei moral -, duas utilizações do conceito de lei civil - como comando do soberano e como medida das ações dos súditos -, bem como as relações que Hobbes estabelece entre os dois conceitos.

Palavras-chave: lei de natureza, lei civil, jusnaturalismo, Hobbes. 


\begin{abstract}
DIEHL, Frederico. Law of nature and civil law in Hobbes. 2009. 205 f. Thesis (Master Degree) - Faculdade de Filosofia, Letras e Ciências Humanas. Departamento de Filosofia, Universidade de São Paulo, São Paulo, 2009.

Among the discussions concerning Hobbes' political philosophy, the relations between the law of nature and the civil law raise great controversy. Two points related to the law of nature remain unsolved. The first one deals with its imperative character: does the law of nature have the force of a true command in the state of nature or is it a mere recommendation? The second point deals with its relation with the civil law: are they the same, are they contradictory, are they complementary? Aiming to answer these questions, this work analyses three different uses of the law of nature concept - as a rational precept, as a command of God and as moral law -, two uses of the civil law concept - as a command of the sovereign and as a rule for the subjects' actions -, as well as the relations that Hobbes states between those two concepts.
\end{abstract}

Key words: law of nature, civil law, jusnaturalism, Hobbes. 


\section{SUMÁRIO}

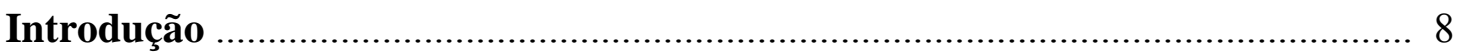

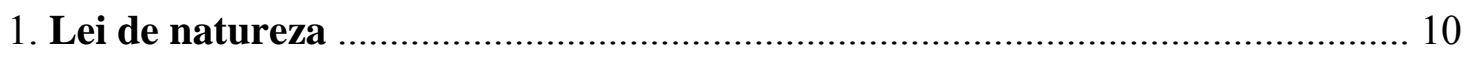

1.1. Lei de natureza como preceito racional ................................................. 14

1.2. Lei de natureza como comando de Deus ................................................ 69

1.3. Lei de natureza como lei moral ............................................................ 88

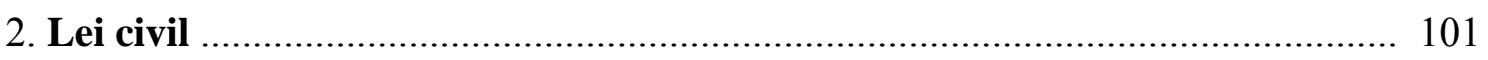

2.1. Lei civil como comando do soberano ............................................... 103

2.2. Lei civil como medida das ações dos súditos ....................................... 120

3. Relações entre lei de natureza e lei civil ...................................................... 136

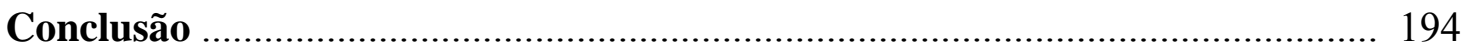

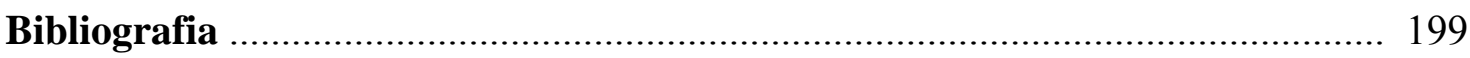




\section{Introdução}

É recorrente na história da filosofia a concepção de que há uma lei anterior à lei humana, que a valida e lhe é superior. Essa lei, chamada usualmente de lei de natureza ${ }^{1}$, concebida pelos primeiros filósofos gregos, foi intensamente utilizada pelos jusnaturalistas modernos. As teorias da lei de natureza desses filósofos dos séculos XVII e XVIII “constituem de diversas maneiras a mais importante linguagem da política e da ética na Europa, influente sobre uma imensa área e sobre uma ampla variedade de disciplinas" ${ }^{2}$. Dentre tais autores, Thomas Hobbes foi um dos principais.

A lei constitui um dos principais temas da reflexão filosófica de Hobbes $^{3}$. Dentro desse tema, esta dissertação insere-se no chamado "caso da lei

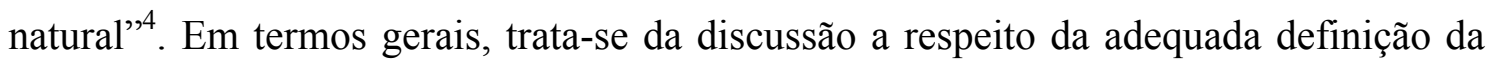
lei de natureza no pensamento de Hobbes; em especial, investiga sua obrigatoriedade. $\mathrm{O}$ interesse pela questão já dura um bom tempo: a polêmica Taylor-Warrender teve início nas primeiras décadas do século $\mathrm{XX}^{5}$. Desde então os estudiosos não deixaram de lidar

\footnotetext{
${ }^{1}$ Como Hobbes usa indistintamente as expressões law of nature, natural law e law of the nature, são usadas também indistintamente lei de natureza, lei natural e lei da natureza. Analogamente, as expressões human law, positive law, political law e civil law, ou seja, lei humana, lei positiva, lei política e lei civil, também são empregadas com o mesmo sentido.

${ }^{2}$ Richard TUCK, The 'modern' theory of natural law, p. 119.

${ }^{3}$ Nesse sentido, pode-se afirmar que "[d]iscussões sobre a lei ocupam um lugar proeminente em todos os três principais trabalhos de Hobbes sobre filosofia política (...). Discussões sobre lei são recorrentes em seus escritos porque a lei e a teoria jurídica estão profundamente envolvidas com sua filosofia moral e política por meio de suas concepções de soberania e de Estado". M. M. GOLDSMITH, Hobbes on law. E que "a lei é de longe o conceito mais importante na obra filosófica de Hobbes". A. P. MARTINICH, A Hobbes dictionary, p. 176.

${ }^{4}$ Cf. W. H. GREENLAF, Hobbes: o problema da interpretação, p. 60. Ver também Marcelo Gross VILLANOVA, Lei natural e lei civil na filosofia política de Thomas Hobbes, pp. 13 e 14.

${ }^{5} \mathrm{O}$ texto de A. E. Taylor que deu origem ao debate, The ethical doctrine of Thomas Hobbes, é de 1938. Em linhas gerais, a polêmica - que é tratada no primeiro capítulo da presente dissertação - cuida da obrigatoriedade da lei de natureza no estado de natureza em função do seu aspecto de comando divino.
} 
com esse assunto, sem haver ainda um consenso entre a comunidade acadêmica, com diversas interpretações recentes ${ }^{6}$.

Dentro desse "caso da lei natural", um ponto específico vem sendo bastante estudado: a relação entre lei natural e lei civil. A partir de meados do século XX diversos intérpretes vêm abordando tal relação ${ }^{7}$.

Visto que não há acordo entre os comentadores sobre a definição de lei natural e tampouco sobre a relação entre lei natural e lei civil em Hobbes, este trabalho assume a idéia de que a dificuldade em compreender essa relação vem do fato de não existir uma formulação precisa nem do que é lei natural e nem do que é lei civil no pensamento de Hobbes. Como é difícil dizer exatamente em que cada uma dessas duas coisas consiste, fica conseqüentemente difícil relacioná-las.

Objetivando evitar as imprecis鮡s nos conceitos de lei natural e lei civil, este trabalho opta por analisar a multiplicidade de sentidos desses termos, como forma de aclarar as diferentes rela珲es que Hobbes estabelece entre as duas leis.

De modo que a dissertação é composta por três capítulos: um sobre lei de natureza, outro sobre lei civil e outro sobre as relações entre ambas. Os capítulos são divididos em tópicos, cada um tratando de um dos diferentes sentidos da lei natural ou da lei civil, na ordem em que tais sentidos são mobilizados na argumentação de Hobbes. No interior dos tópicos, primeiramente é exposto um histórico do tratamento que cada concepção recebeu antes de Hobbes. A seguir, é apresentada em linhas gerais a maneira com que Hobbes trabalha as diferentes noções. Na seqüência, estas são analisadas

\footnotetext{
${ }^{6}$ Por exemplo: Lei natural e lei civil na filosofia política de Thomas Hobbes, de Marcelo Gross VILLANOVA, de 2008; e Reason as reckoning: Hobbes's natural law as right reason, de Jeffrey Barnouw, também de 2008.

${ }^{7}$ O texto Lei natural e lei civil na filosofia política de Thomas Hobbes, de Norberto BOBBIO, é de 1954. Além dele, dedicam-se à questão, por exemplo, G. M. Chiodi, Charles Yves Zarka, Cícero Araújo, Rita Helena Sousa Ferreira Gomes e Marcelo Gross Villanova.
} 
conforme discutidas em cada um dos textos (aqui, obedecendo-se a ordem cronológica de composição de cada obra). Posteriormente, são expostas as interpretações a respeito dos temas discutidos, para enfim serem feitas considerações a respeito dos pontos em debate. 


\section{Lei de natureza}

A lei de natureza ocupa um papel central na filosofia de Hobbes. Afinal, são as determinações da lei natural que levam o homem a sair do estado de guerra e ingressar no Estado civil ${ }^{8}$. A sobrevivência humana e a possibilidade de paz dependem, em última instância, dessas determinações.

Tal centralidade é atestada pela profusão de estudos sobre a lei de natureza em Hobbes. Entre esses estudos é comum a discussão a respeito da dificuldade em se delimitar precisamente o conceito - o que causa estranhamento se tomarmos em conta o projeto filosófico do autor.

Hobbes afirma, em diferentes ocasiões ${ }^{9}$, que o grande problema da filosofia política é a falta de acordo entre os filósofos. Mas tal ausência de entendimento não se observa de forma tão grave entre os matemáticos e os filósofos naturais. Por quê? A diferença reside no método utilizado ${ }^{10}$. Estimulado pelas impressionantes conquistas da ciência moderna então nascente e inspirado "pela epistemologia de Bacon e de Galileu, cujo mérito foi o de acrescentar à reflexão racional a observação experimental"11, Hobbes conclui que somente por meio do método geométrico, que parte de axiomas irrefutáveis e caminha passo a passo em direção a conclusões seguras,

\footnotetext{
${ }^{8}$ De maneira sintética: "[h]á certas paixões, diz Hobbes, que inclinam os homens à paz: medo da morte, desejo das coisas que são necessárias para uma vida confortável e a esperança de as conseguir por meio do trabalho. A razão, por conseguinte, sugere adequados artigos de paz, pelos quais os homens podem chegar num acordo, e dita para cada homem que para o seu próprio bem eles devem buscar a paz, na medida em que exista esperança de a obter. Esses artigos de paz não são nada mais que as chamadas leis de natureza". Huntington CAIRNS. Hobbes' theory of law, p. 66. Cf. também Norberto BOBBIO, Thomas Hobbes, p. 40.

${ }^{9}$ Elementos da lei natural e política, doravante Elementos, p. 17, Do cidadão, p. 5, e Diálogo entre um filósofo e um jurista, doravante Diálogo, p. 35, por exemplo.

${ }^{10}$ Sobre método em geral, conferir o capítulo VI do primeiro livro do De corpore. Sobre o método específico da ciência civil, conferir o § 7 do mesmo capítulo.

${ }^{11}$ Simone GOYARD-FABRE, Le droit et la loi dans la philosophie de Thomas Hobbes, p. 22. Lembrando que Hobbes esteve em toda sua vida madura em estreito contato com os grandes cientistas de sua época: foi secretário de Bacon e amigo de Galileu Galilei, Marin Mersenne e Pierre Gassendi.
} 
é que se pode atingir um conhecimento certo e inquestionável ${ }^{12}$. Desse modo, "de acordo com Hobbes, a ciência natural deveria ter a forma de demonstrações geométricas. Axiomas como definições, segundo Hobbes, deveriam ser estabelecidos e então inferências necessárias deveriam ser tiradas deles. A ciência deveria ser conseqüentemente certa, a priori e necessária"13. A partir dos primeiros princípios, inquestionáveis, a razão iria operando por deduções em direção a conclusões certas e $\operatorname{seguras}^{14}$.

O problema, para Hobbes, é que os autores de filosofia política e moral nunca haviam usado tal método. Hobbes atribui a si a tarefa, considerando-se o primeiro autor a fazer realmente uma ciência da política ${ }^{15}$. A aspiração central da filosofia civil de Hobbes seria justamente "a de transformar o estudo da teoria moral e política numa disciplina científica" ${ }^{\text {16 }}$. Pode-se dizer que,

para Hobbes, (...), persiste um sentido no qual a recta ratio pode ser apropriadamente descrita como infalível. Se seguirmos devidamente os quatro passos da ciência ${ }^{17}$, não haverá como deixarmos de chegar à scientia verdadeira, a

\footnotetext{
${ }^{12}$ Tal preocupação não é exclusiva de Hobbes, sendo bastante comum entre os filósofos do século XVII, como Descartes e Pascal. Em Descartes, encontra-se o tema discutido no Discurso do método, p. 69, e em Pascal no primeiro de seus pensamentos, em Pensamentos, p. 69.

${ }^{13}$ A. P. MARTINICH, Hobbes: a biography, p. 85.

14 "Para reduzir essa doutrina [da justiça e da sociedade] às regras e à infalibilidade da razão, não há caminho além de, primeiro, derrubar tais princípios [os disputáveis] em troca de uma fundação, com a paixão insuspeitada, que não se possa remover; e, em seguida, erguer sobre isso a verdade de casos na lei de natureza (a qual até agora tem sido construída sobre o ar) passo a passo, até que o conjunto seja irreprimível". Elementos, Epístola dedicatória, pp. 17 e 18.

${ }^{15} \mathrm{Na}$ introdução ao De corpore, Hobbes afirma que "[a] Filosofia Natural é portanto muito jovem; mas a Filosofia Civil é ainda mais jovem, sendo não mais antiga (...) que o meu próprio livro De Cive [Do cidadão]". De corpore, Epístola Dedicatória, p. IX. The English Works of Thomas Hobbes of Malmesbury, Volume I, Ed. Molesworth. Apesar de os Elementos terem sido redigidos antes, Do cidadão foi publicado antes.

${ }^{16}$ Quentin SKINNER, Razão e retórica na filosofia política de Hobbes , p. 17.

${ }^{17}$ Os quatro passos são os seguintes: primeiro, recebem-se as concepções pelos sentidos; segundo, nomeiam-se tais concepções; terceiro, combinam-se os nomes das concepções na formação de proposições; quarto, juntam-se essas proposições de forma que se obtenha delas uma conclusão. Cf. Elementos, p. 45.
} 
um conhecimento ou compreensão genuínos das questões implicadas ${ }^{18}$.

É por esse motivo que

a ciência civil pode e deve ser classificada entre as ciências demonstrativas. Em outras palavras, ele [Hobbes] insiste que seus quatro passos da ciência são tão aplicáveis ao raciocínio moral quanto ao matemático. Decorre daí que é possível esperarmos construir uma verdadeira ciência da política, capaz de fornecer suas conclusões com segurança ${ }^{19}$.

É discutível, entretanto, se a filosofia política hobbesiana tem autonomia face a suas premissas físicas e antropológicas. Hobbes procura deixar bem claro que seu sistema é um todo do qual uma parte só é compreensível por dedução lógica de seus fundamentos ${ }^{20}$, podendo-se afirmar que "nem o direito e nem a lei são independentes da natureza humana" ${ }^{21}$. Mas, no prefácio de Do cidadão o filósofo também afirma que sua ciência da política pode muito bem subsistir sem os postulados que lhe antecedem ${ }^{22}$. De forma que, por outro lado, também é possível afirmar que “[s]ua teoria jurídica portanto não é necessariamente uma dedução das leis mecânicas"23.

Apesar desse pretenso rigor geométrico da filosofia hobbesiana, são diversos os autores que frisam suas contradições, imprecisões e exageros: "[m]uitos dos

\footnotetext{
${ }^{18}$ Quentin SKINNER, Razão e retórica na filosofia política de Hobbes , p. 398.

${ }^{19}$ Quentin SKINNER, Razão e retórica na filosofia política de Hobbes , p. 401.

${ }^{20}$ Cf. Elementos, p. 19.

${ }^{21}$ Simone GOYARD-FABRE, Le droit et la loi dans la philosophie de Thomas Hobbes, p. 15.

22 "Sucede que aquilo que era último na ordem veio a lume primeiro no tempo, e isso porque vi que esta parte, fundada em seus próprios princípios suficientemente conhecidos pela experiência, não precisaria das partes anteriores". Do cidadão, p. 18.

${ }^{23}$ Huntington CAIRNS, Hobbes' theory of law, p. 62.
} 
comentadores de Hobbes têm dirigido sua atenção às numerosas inconsistências encontradas em seus trabalhos",24.

Há, por exemplo, quem defenda que “Hobbes usa o termo 'direito' em dois sentidos (...). Primeiro, há os que podem ser chamados de direitos de ação ou direitos permissivos (...). Em segundo lugar, há os que podem ser chamados de direitos de recepção ou pretensão a outros" ${ }^{, 25}$. A lei de natureza, da mesma forma, também pode ser considerada ambígua: "Hobbes apresenta um projeto de privilegiar a lei positiva em detrimento da lei natural. Um dos motivos para estabelecer essa prerrogativa da lei positiva pode ser a ambigüidade das leis naturais" ${ }^{26}$. Além disso, o termo lei de natureza nem sempre é usado com o mesmo sentido: “às vezes Hobbes iguala as leis naturais e civis às leis divinas e humanas, respectivamente. Esta nomenclatura alternativa tem causado problemas para os intérpretes",27.

O presente capítulo propõe uma análise fundada em três diferentes usos para a expressão lei de natureza na obra de Hobbes: como preceito racional, como comando de Deus e como lei moral. Hobbes defende, em diferentes situações, que a lei de natureza é um preceito da razão, que a lei de natureza é uma ordem divina e que a lei de natureza é uma lei moral. O filósofo ainda aproxima a lei natural da lei civil em certas situações, mas as relações entre as duas são desenvolvidas em capítulo próprio desta pesquisa. Além disso, em alguns momentos Hobbes afirma que a lei das nações é a mesma coisa que a lei da natureza; contudo, não desenvolve tal assertiva ${ }^{28}$.

\footnotetext{
${ }^{24}$ B. T. TRAINOR, Hobbes on political allegiance and obligation, p. 321.

${ }^{25}$ D.D. RAPHAEL, Obligations and rights in Hobbes, p. 150.

${ }^{26}$ Marcelo Gross VILLANOVA, Lei natural e lei civil na filosofia política de Thomas Hobbes (dissertação), p. 107. Via de regra, é citado o livro de VILLANOVA. Quando for feita menção à dissertação de mestrado com o mesmo nome, a ocorrência é explicitada.

${ }^{27}$ A. P. MARTINICH, Hobbes: a biography, p. 231.

${ }^{28}$ Elementos, p. 216, e Do cidadão, pp. 9 e 219 ,
} 


\subsection{Lei de natureza como preceito racional}

$\mathrm{O}$ primeiro e mais importante sentido que Hobbes atribui à lei de natureza é o de preceito racional.

Antes, contudo, de ser examinado esse tratamento que Hobbes dá à expressão, é importante ver suas origens. De fato, pode-se defender que Hobbes estava prosseguindo e contribuindo com tradições já existentes na filosofia política, ao mesmo tempo em que as refinava e modificava. É fato que "a idéia de lei natural inscreve-se numa longa tradição filosófica que Hobbes certamente não ignorava" ${ }^{29}$. De maneira que estudar Hobbes em relação a seus antecessores e a seu contexto intelectual ajuda a entender melhor a natureza de sua contribuição para a teoria política ${ }^{30}$, além de um ganho considerável na compreensão de seu próprio raciocínio.

Desde o início do jusnaturalismo ${ }^{31}$, a noção de lei de natureza esteve identificada com a noção de razão. Como em boa parte dos temas filosóficos, "é na Grécia que descobriremos os germes da teoria do direito natural"32.

Pode-se afirmar que "a doutrina do direito natural é tão antiga quanto a filosofia ocidental"33. É principalmente em Heráclito que os estudiosos reconhecem o início das formulações de lei de natureza enquanto ditame da razão: “[o] logos heraclitiano, em particular, constitui o precedente da teoria estóica das razões seminais (logoi spermatikoi), e, mais remotamente, da teoria cristã da lex aeterna"34. Além disso, "no conceito de logos devemos reconhecer o contributo essencial de Heráclito para a

\footnotetext{
${ }^{29}$ Simone GOYARD-FABRE, Le droit et la loi dans la philosophie de Thomas Hobbes, p. 46.

${ }^{30}$ Cf. Quentin SKINNER, The ideological context of Hobbes's political thought, p. 287.

${ }^{31}$ Por jusnaturalismo entende-se a teoria que fundamenta a lei e o direito na natureza, e não na convenção humana.

${ }^{32}$ Michel VILLEY, A formação do pensamento jurídico moderno, p. 16. Defendendo a mesma idéia, cf. Norberto BOBBIO, Locke e o direito natural, p. 23.

${ }^{33}$ Norberto BOBBIO, Igualdade e dignidade dos homens, in O terceiro ausente, p. 85.

${ }^{34}$ A. Truyol SERRA, História da filosofia do direito e do Estado. Volume I: das origens, à baixa Idade Média. Portugal (sem indicação de cidade), 1986, Instituto de Novas Profissões. pp. 89 e 90.
} 
filosofia jurídica" ${ }^{35}$. É por ser comum a todos os homens que a razão (ou logos) seria o fundamento da lei natural, referente a todos os casos e a todas as pessoas.

Mesmo que presente entre os gregos até o helenismo (Platão, por exemplo, submeteu a lei à razão ${ }^{36}$ ), é com o estoicismo que a razão passa a preponderar na lei natural. Haveria, para os filósofos estóicos, um elemento responsável pela organização e desenvolvimento da natureza, a razão ou logos, presente em todos os seres. Era esse elemento racional que garantiria coesão e unidade a todos os seres. Mas somente nos deuses e na alma humana a razão estaria presente em estado puro - por tal motivo é que o homem, criatura racional, desfrutaria de lugar especial entre os demais seres. Essa razão presente no homem é que seria, para os estóicos, o fundamento da sociedade e do direito ${ }^{37}$.

As normas estabelecidas pelos homens para viver em sociedade podiam ser julgadas a partir de um princípio designado pelos estóicos de lei natural. Era uma lei não instituída, pura exigência da razão, também chamada lei divina ou eterna, donde as leis humanas tiravam seu fundamento. Refletia a justa razão, essa razão suprema imanente à natureza que regulava o curso dos astros e que governava todo o universo ${ }^{38}$.

Para os estóicos, portanto, tudo o que existisse - toda a natureza - era repleto de razão. Tudo seria governado por uma lei racional, a qual poderia ser descoberta pelo homem pois possuidor de razão - como fundamento de suas próprias leis.

\footnotetext{
${ }^{35}$ A. Truyol SERRA, História da filosofia do direito e do Estado. Volume I: das origens, à baixa Idade Média. Portugal (sem indicação de cidade), 1986, Instituto de Novas Profissões. p. 90. A respeito da identificação da lei com a razão no pensamento de Heráclito, cf. também Arlene W. SAXONHOUSE, Hobbes and the beggining of modern political thought, p. 150.

${ }^{36}$ Veja-se, por exemplo, a seguinte passagem: "[c]om efeito, nem a lei nem ordenamento algum valem mais do que a inteligência; nem corresponde à ordem das coisas que a inteligência seja sujeita ou escrava de quem quer que seja, mas que governe sobre tudo, já que se apóia sobre a verdade, e seja efetivamente livre, conforme à sua natureza". PLATÃO, As leis, p. 392.

${ }^{37}$ Cf. Alberto Ribeiro de BARROS, Direito natural em Cícero e em Tomás de Aquino, p. 44.

${ }^{38}$ Alberto Ribeiro de BARROS, Direito natural em Cícero e em Tomás de Aquino, p. 44.
} 
Cícero, um dos filósofos mais importantes do jusnaturalismo antigo, é identificado com o estoicismo ao tratar do tema da lei, em especial no tocante ao vínculo entre lei de natureza e razão.

Na sua filiação eclética, Cícero trouxe do estoicismo essa crença em um universo racionalmente ordenado, na presença inata em todos os homens de uma razão, que atribui a cada ser as características de sua essência e o fim para o qual está direcionado, e principalmente na consubstancialidade desta razão com a alma humana (...): a lei é a razão soberana introduzida na natureza, que nos ordena o que devemos fazer e nos proíbe o contrário. Essa razão, quando ela se apóia e se realiza no pensamento do homem, é lei ${ }^{39}$.

O jurista romano trata de lei de natureza principalmente em duas obras, Da república e Das leis. Em Da república, após a exposição de Filão do ponto de vista de Carnéades ${ }^{40}$, para o qual não haveria justiça natural ${ }^{41}$, mas apenas convencional, Lélio faz uma defesa do ponto contrário. Apesar de não usar a expressão lei de natureza, a definição dada para a lei é em função de seu aspecto racional:

A reta razão, conforme à natureza, gravada em todos os corações, imutável, eterna, cuja voz ensina e prescreve o bem, afasta do mal que proíbe e, ora com seus

\footnotetext{
${ }^{39}$ Alberto Ribeiro de BARROS, Direito natural em Cícero e em Tomás de Aquino, pp. 44 e 45.

${ }^{40}$ Carnéades, filósofo cético dos séculos III e II a.C. Hugo Grócio usa, nos prolegômenos de $O$ direito da guerra e da paz, a mesma estratégia de Cícero: elege Carnéades como o representante da visão a ser combatida.

${ }^{41}$ Entre os autores antigos, muitas vezes não havia distinção entre os conceitos de lei natural, direito natural e justiça natural. Mesmo a lei de natureza era muitas vezes chamada apenas de lei. Há quem diga que foi Hobbes o primeiro a formular uma distinção precisa entre lei e direito (cf. Leo STRAUSS, The political philosophy of Hobbes: its basis and its genesis, p. 157), uma vez que na língua inglesa o vocábulo law designa tanto o que se entende por lei como o que se entende por direito. "Na sua teoria da lei positiva Hobbes afinal colocou seu dedo sobre uma distinção vital. Ele buscou uma separação que, nos idiomas continentais, é expressa por palavras separadas: ius-lex; diritto-legge; droit-loi; Recht-Gesetz; derecho-ley [e que em português correspondem a direito e lei], mas que em inglês é indicada apenas pela diferença entre os termos 'lei' [law] ou 'a lei' [the law] e 'uma lei' [the law] ou 'as leis' [the laws]". Huntington CAIRNS, Hobbes' theory of law, p. 71.
} 
mandamentos, ora com suas proibições, jamais se dirige inutilmente aos bons, nem fica impotente ante os maus. Essa lei não pode ser contestada, nem derrogada em parte, nem anulada; não podemos ser isentos de seu cumprimento pelo povo nem pelo Senado; não há que procurar para ela outro comentador nem intérprete; não é uma lei em Roma e outra em Atenas, uma antes e outra depois, mas uma, sempiterna e imutável, entre todos os povos e em todos os tempos ${ }^{42}$.

O tema é explorado com maiores desenvolvimentos em Das leis. Sobretudo nos primeiros dois livros desta obra Cícero realiza uma série de reflexões sobre o assunto. A lei tem como definição justamente seu aspecto de razão: “[a] lei é a razão suprema da Natureza, que ordena o que se deve fazer e proíbe o contrário. Esta mesma razão, uma vez confirmada e desenvolvida pela mente humana, se transforma em lei"43.

Com o cristianismo, o teor racional da lei de natureza cede importância face ao mando divino. "A lei natural passa a ser - direta ou indiretamente - a lei de Deus" ${ }^{\text {44 }}$. Mas nem por isso a razão deixa de ser considerada. Ela é um dos meios pelos quais o homem pode descobrir as leis naturais criadas por Deus. Elas "podem ser descobertas pelo homem a quem Deus as manifestou - de forma direta, com a revelação, ou indiretamente, pela razão" ${ }^{45}$. Em Tomás de Aquino, por exemplo,

a lei natural é o modo como a ordem cósmica, emanada de Deus, manifesta-se naquele aspecto da criação que é a criatura dotada de razão, isto é, o homem. A lei natural consta de um princípio único e genérico do qual a razão deduz todos os outros. Esse preceito muito genérico

\footnotetext{
${ }^{42}$ CÍCERO, Da república, Livro III, § XVII, p. 69.

${ }^{43}$ CÍCERO, Das leis, Livro I, § 18, p. 40.

${ }^{44}$ Norberto BOBBIO, Locke e o direito natural, p. 37.

${ }^{45}$ Norberto BOBBIO, Locke e o direito natural, p. 37.
} 
consiste na máxima bonun faciendum, male vitandum, que prega fazer o bem e evitar o mal ${ }^{46}$.

A lei humana seria, por conseguinte, obtida por derivação, pelo uso das suas faculdades racionais, a partir da lei natural.

Entre os filósofos escolásticos e Hobbes, Hugo Grócio é tido como o maior teórico do direito natural, sendo o seu Direito da guerra e da paz considerado o "texto de fundação da escola moderna da lei natural"47. Crítico do pensamento cético característico do humanismo, pode ser considerado o precursor direto de Hobbes: "Grotius foi seguido de perto por John Selden, Thomas Hobbes e acima de todos Samuel Pufendorf" ${ }^{, 48}$, tornando-se um modelo para todos os estudiosos da lei de natureza $^{49}$. Para Grócio, a lei de natureza poderia ser bem identificada com as leis da razão. No desenvolvimento de seus escritos, entre De jure praedae comentarius e o Direito da guerra e da paz, Grócio chegou mesmo a tornar Deus prescindível para uma teoria da lei natural: as leis de natureza vigoram mesmo na hipótese de que não exista um Deus $^{50}$. O direito seria como um elemento da natureza, para o qual o homem olha e, pela razão, conhece. Grócio defende que todo animal busca sua preservação, e faz de tudo para mantê-la. Esse instinto é governado pelo entendimento humano, ou reflexão racional, para o bem da sociedade, como presente na seguinte passagem:

[e]ste cuidado pela vida social, de que falamos de modo muito superficial, e que é de todo conforme ao entendimento humano, é o fundamento do direito propriamente dito, ao qual se referem o dever de se abster do bem de outrem, de resistir àquilo que, sem ser nosso,

\footnotetext{
${ }^{46}$ Norberto BOBBIO, Locke e o direito natural, p. 38.

${ }^{47}$ Richard TUCK, The 'modern' theory of natural law, p. 108.

${ }^{48}$ Richard TUCK, The 'modern' theory of natural law, p. 100.

${ }^{49}$ Richard TUCK, The 'modern' theory of natural law, p. 104.

${ }^{50}$ Hugo GRÓCIO, Direito da guerra e da paz, p. XIX, citado por Richard TUCK, The 'modern' theory of natural law, p. 112.
} 
está em nossas mãos ou o lucro que disso tiramos, a obrigação de cumprir as promessas, a de reparar o dano causado por própria culpa e a aplicação dos castigos merecidos entre os homens ${ }^{51}$.

As regras básicas para a convivência humana estão presentes na própria natureza, consistindo em deveres dados pela razão e acessíveis também pela razão ${ }^{52}$. É a reta razão, e não mais Deus, que proíbe o que é repugnante à sociedade ${ }^{53}$. A razão, para Grócio, não consiste apenas na capacidade de cálculo, mas é também a faculdade que permite o conhecimento do que está ou não de acordo com a natureza humana ${ }^{54}$.

A visão de Grócio, como mencionado, passou a preponderar. De forma que, em relação à sua própria época, Hobbes não foi um autor isolado. Muitas de suas proposições eram tratadas por contemporâneos, a partir de uma abordagem independente, como por exemplo em Anthony Ascham ou Marchamont Nedham ${ }^{55}$. A partir disso Quentin Skinner conclui que, contrariamente ao que sempre se pensou, Hobbes não foi um autor singular, e sim que suas idéias participavam de um certo “clima de opiniões" da época ${ }^{56}$.

\section{Lei de natureza como preceito racional em Hobbes}

A lei de natureza é definida inicialmente por Hobbes como preceito da razão ${ }^{57}$, sendo ainda a formulação mais importante e mais freqüente nas suas principais

\footnotetext{
${ }^{51}$ Hugo GRÓCIO, Direito da guerra e da paz, prolegômenos, p. 39.

${ }^{52}$ Hugo GRÓCIO, Direito da guerra e da paz, prolegômenos, p. 42.

${ }^{53}$ Cf. Richard TUCK, The 'modern' theory of natural law, p. 112.

${ }^{54}$ Hugo GRÓCIO, Direito da guerra e da paz, livro primeiro, capítulo I, p. 69.

${ }^{55}$ Quentin SKINNER, The ideological context of Hobbes's political thought, p. 309.

${ }^{56}$ Quentin SKINNER, The ideological context of Hobbes's political thought, p. 309.

${ }^{57}$ Além de preceito, Hobbes usa também os termos ditame, ditado, conselho, postulado e recomendação como sinônimos.
} 
obras de filosofia política ${ }^{58}$. É a mais importante porque se localiza no fundamento do seu sistema. Se a filosofia hobbesiana segue o espírito do racionalismo de seu tempo, formulando um sistema ${ }^{59}$ no qual, a partir de noções fundamentais, derivam-se delas os conceitos que formam o edifício do conhecimento ${ }^{60}$, então a lei de natureza como preceito racional é um dos alicerces principais desse edifício.

De modo geral, nos três livros em que Hobbes aborda o tema de maneira mais sistemática (quais sejam, os Elementos, o Do cidadão e o Leviatã), o autor usa o mesmo expediente para tratar a lei natural como preceito da razão. Antes de defini-la, o filósofo adianta em alguns pontos a existência de uma regra racional para se obter a paz, sem, contudo, nomeá-la. Depois, define lei natural como sendo um ditame racional, aplicando essa definição na enumeração das leis de natureza em espécie. Após esse procedimento, a concepção é empregada mais algumas vezes no decorrer das obras.

Nos tópicos a seguir, é examinada de forma mais detalhada a argumentação de Hobbes, na ordem em que foi exposta em seus textos.

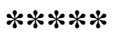

Em 1996 foi publicado um volume com três textos apenas recentemente atribuídos a Hobbes ${ }^{61}$. A autoria dos textos vinha sendo discutida há tempos, sabendo-se apenas que eles foram produzidos na residência da família Cavendish. E Hobbes, como se sabe, após sair da universidade tornou-se tutor dos jovens da família, cargo que exerceu, salvo alguns períodos dedicados a outras famílias, pelo resto da vida. Os textos, juntamente com nove outros, haviam sido publicados num volume anônimo,

\footnotetext{
${ }^{58}$ B.J. Messelman, Razão inconsciente e a suspeita do improvável, p. 69.

${ }^{59}$ Cf. Simone GOYARD-FABRE, Le droit et la loi dans la philosophie de Thomas Hobbes, p. 40.

${ }^{60} \mathrm{Cf}$. Maria Isabel LIMONGI, Hobbes, p. 14.

${ }^{61}$ Thomas HOBBES, Three discourses. Editado por Noel B. Reynolds e Arnele W. Saxonhouse e publicado pela University of Chocago Press.
} 
portando o título de Horae subsecivae ${ }^{62}$, em 1620, sob forte influência do estilo de Francis Bacon ${ }^{63}$. Com novos métodos de determinação de autoria, pôde-se concluir com razoável segurança que três desses dozes textos foram escritos por Hobbes ${ }^{64}$.

E um desses textos, A discourse of laws, tem como tema justamente a lei. Nota-se claramente a influência de Cícero, citado nominalmente, tanto em sua forma como em seu conteúdo. No discurso, após dizer que as leis possuem natureza de medida para as ações, dividindo-as em suas espécies, Hobbes chega à definição de lei. A lei é definida pelo filósofo como razão:

Lei e Razão são gêmeos, a falta de um é a deformidade do outro; são de um tipo convertibilia [passível de ser convertido], e inseparáveis. A razão comum que temos gravadas [engrafted] em nossas naturezas, é a Lei, dirigindo o que nós temos de fazer, proibindo o contrário, de acordo com Cícero: Eadem ratio cum est in hominis mente confirmata, \& confecta, lex est ${ }^{65}$. Pois Lei é nada mais que razão dilatada [dilated] e aplicada em diversas ocasiões e acidentes. (...) E a esse respeito, e a obrigação [duty] que devemos [owe] à lei, é nada mais que a obediência à razão, que é a progenitora [begetter], a corretora, e a preservadora, das próprias Leis: aqueles então que não as obedecem, ficam mais próximos da

\footnotetext{
${ }^{62}$ Em inglês o termo quer dizer leisure hours; em português pode ser traduzido por horas de lazer.

${ }^{63}$ Noel B. REYNOLDS e Arlene W. SAXONHOUSE, Hobbes and the Horae subsecivae, p. 4. Os Ensaios de Bacon foram publicados em 1612.

${ }^{64}$ Confirmando a sugestão de Leo Strauss de que seria Hobbes mesmo o autor dos textos. Cf. Noel B. REYNOLDS e Arlene W. SAXONHOUSE, Hobbes and the Horae subsecivae, p. 4. Contra, defendendo que os textos não são de Hobbes, mas sim de seu pupilo, veja-se Richard TUCK, Hobbes (edição inglesa), p. 13: "A casa dos Cavendish também escreveu ensaios ao estilo de Bacon sobre vários assuntos, num volume que sobreviveu até hoje; pensou-se que eram de Hobbes, mas agora se sabe que eram de fato de seu pupilo". E também SKINNER, Hobbes and republican liberty, p. 69. Não se procura, neste trabalho, entrar na polêmica acerca da verdadeira autoria do texto: considera-se que, mesmo que redigidos pelo pupilo de Hobbes, os textos trariam visões semelhantes às suas.

${ }^{65}$ Na nota: "Cícero, De legibus, 1.6.1.8". A passagem pode ser traduzida da seguinte maneira: "essa razão, quando confirmada e estabelecida na mente do homem, é lei”.
} 
natureza dos Brutos e dos Selvagens, do que os homens dotados [endowed] de razão ${ }^{66}$.

A lei é expressamente definida como razão: é a razão comum gravada na natureza de cada homem. É uma concepção nada original - como visto, tal identificação entre lei e razão é encontrada desde os filósofos pré-socráticos: “[p]ara Platão e para Heráclito, e para a teoria medieval da lei natural também, lei é razão e razão deriva da natureza. Não há oposição entre o que é natural e o que as leis comandam"

Tal lei, por ser racional, determina a conduta do homem, o que ele pode ou não pode fazer. A lei trata-se, assim, de uma especificação da razão: a razão que comanda o universo, ao ser determinada para situações concretas, é o que se entende por lei. De maneira que não há oposição entre lei e razão, mas uma identidade quase plena: lei é, além de espécie do gênero razão, também complementar a ela. Uma supre a outra, a completa, e podem suas disposições serem intercambiáveis. Uma não subsiste sem a outra.

Um ponto relevante aqui é que a obrigação que um homem deve à lei é devida em função da racionalidade que permeia a lei. $\mathrm{O}$ homem tem que seguir a lei porque ela é racional. Obedecer à lei é a mesma coisa que obedecer à razão - quem a obedece é civilizado, quem a despreza é selvagem.

Antes da definição de lei mencionada, Hobbes distingue as diferentes espécies do gênero lei. São três os tipos de lei: lei de natureza, lei das nações e lei civil. Mas em nenhum deles desponta, nesse momento, o aspecto racional: as leis são diferenciadas em função da abrangência dos que as devem seguir, e não de sua natureza

\footnotetext{
${ }^{66}$ A discourse of laws, p. 115. Na tradução foram conservados a pontuação e o uso de maiúsculas do original.

${ }^{67}$ Arlene W. SAXONHOUSE, Hobbes and the beggining of modern political thought, p. 150.
} 
intrínseca. A lei de natureza é a lei usufruída ${ }^{68}$ por toda e qualquer criatura viva; a lei das nações é a comum a todos os homens; a lei municipal é a de específica cidade ou nação. A lei de natureza atua, dessa maneira, como o fundamento das demais espécies de $1 i^{69}$.

No texto, diferentemente do disposto nas obras posteriores, Hobbes toma a razão como determinante apenas no conceito de lei das nações. Após apontar a diferença de abrangência de cada espécie de lei, o filósofo discursa a respeito de cada uma delas: "[a]s Leis das Nações são aquelas regras que a razão prescreveu a todos os homens em geral, e como tais todas as Nações umas com as outras as aceitam e as observam por justiça" ${ }^{, 0}$. Bastante interessante notar que o que o filósofo chama aqui de lei das nações é o que ele chama nos demais textos de lei de natureza - as regras dadas aos homens pela razão. Nas outras obras, o autor praticamente ignora a existência da lei das nações, apenas afirmando que elas são a mesma coisa que a lei de natureza. No Discurso sobre as leis, Hobbes estabelece uma distinção conceitual entre lei natural e lei das nações: enquanto lei das nações é a regra racional a ser seguida por todos os homens, a lei de natureza é a que "produz determinadas ações" não só para os homens, mas para todas as criaturas vivas ${ }^{71}$.

O texto não fornece, como visto, uma teoria desenvolvida a respeito da lei. É, como indica seu título, um discurso no qual se toma a lei como assunto principal. Hobbes viria a formular uma teoria mais acabada e desenvolvida somente em suas obras sistemáticas, como visto a seguir.

\footnotetext{
${ }^{68}$ Hobbes usa o termo enjoy.

${ }^{69}$ A discourse of laws, p. 110.

${ }^{70}$ A discourse of laws, p. 110.

${ }^{71}$ A discourse of laws, p. 110.
} 
A primeira obra sistemática de filosofia escrita por Hobbes são os Elementos da lei natural e política ${ }^{72}$. O livro foi escrito em 1640, circulando na época como manuscrito. Foi publicado somente em 1650, como dois tratados separados, intitulados Natureza humana e De corpore politico ${ }^{73}$. Apesar do título, a obra é "um pequeno tratado completo de filosofia, no qual, de resto, a parte de longe mais ampla e mais elaborada é a dedicada à teoria do Estado, a ponto de ser unanimamente considerada a primeira redação da obra maior, Leviathan (Leviatã), publicada em $1651^{\text {}, 74}$. As idéias expressas nos Elementos, desta feita, são essencialmente as mesmas que Hobbes defende e desenvolve até o fim da vida em inúmeras publicações.

Antes de analisar propriamente a lei de natureza, Hobbes sustenta nos Elementos que o que não é contra a razão é exatamente o que os homens chamam comumente de direito, sendo um direito de natureza que os homens possam usar todos os meios possíveis para se preservar, pois a natureza faz os homens buscarem sempre o seu bem e evitarem sempre o seu mal ${ }^{75}$. A razão é, assim, primeiro identificada com o direito e, em especial, com o direito de natureza.

Posteriormente, ao tratar do estado de natureza e do direito natural que nele vigora, Hobbes adianta a noção de que a razão ordena ao homem buscar a paz. Dada a igualdade natural entre os homens, nenhum deles, por mais forte e astuto que seja, consegue assegurar sua preservação por muito tempo. Por isso, os homens devem fazer uso da razão para saírem desse estado de precariedade e conseguirem se preservar:

\footnotetext{
${ }^{72}$ A respeito do título, a referência mais óbvia e direta são os Elementos de Euclides. É sabido que Hobbes foi despertado para a filosofia a partir da leitura de Euclides. Francis Bacon, de quem Hobbes foi secretário, escreveu ainda uma obra chamada justamente Elementos da lei. Cf. M. M. GOLDSMITH, Hobbes on law, p. 274.

${ }^{73}$ M. M. GOLDSMITH, Hobbes on law, p. 274.

${ }^{74}$ Norberto BOBBIO, Thomas Hobbes, p. 23. Para o mesmo autor: “[o] núcleo central da teoria já se encontra plenamente exposto e explicitado nos Elements, permanecendo inalterado nas obras sucessivas". Thomas Hobbes, p. 24.

75 Elementos, XIV, $\S 6$, p. 95. Interessante observar que buscar o bem e evitar o mal corresponde à definição tomista de lei natural.
} 
“[a] razão dita, portanto, que cada homem, para o seu próprio bem, procure a paz à medida que existir a esperança de consegui-la"76. Ordena também que o homem se fortaleça para se defender contra quem não quer a paz. Essa idéia, praticamente a formulação pronta e acabada de lei natural, é retomada e desenvolvida na seqüência do texto.

A razão como elemento que permite ao homem se conservar tem origem no pensamento cético, sendo mais desenvolvida entre os estóicos, com ecos muito fortes em Grócio. Para os céticos, "a única coisa que não excluímos desta vida era, entretanto, o simples desejo de autopreservação" "77. E os estóicos também consideram que "o desejo primário do homem era preservar a si mesmo"78. É esse um dos raros pontos de contato entre as concepções céticas e estóicas, que não deixou de ser aproveitado por Grócio: "[n]esse ponto dos escritos dos céticos pós-renascentistas (e talvez naqueles do próprio Carnéades), o ceticismo logrou ficar de mãos dadas com o estoicismo, pois os estóicos também argumentavam que o desejo primário do homem era o de preservar a si mesmo" ${ }^{, 79}$. Seguindo tais formulações, e animado pela concordância entre as concepções clássicas, Grócio argumenta que as duas primeiras leis da natureza são a de que, em primeiro lugar, é permitido ao homem defender a si mesmo e a de que, em segundo lugar, o homem pode obter coisas que sejam úteis para sua vida ${ }^{80}$. Essas duas noções seriam tão fundamentais que não poderiam ser negadas por homem nenhum - daí seu lugar como fundamento do sistema. De acordo com Tuck, é essa autopreservação o caminho "que leva diretamente a Hobbes" $"$.

\footnotetext{
${ }^{76}$ Elementos, XIV, § 14, p. 96.

${ }^{77}$ TUCK, The 'modern' theory of natural law, p. 110.

${ }^{78}$ TUCK, The 'modern' theory of natural law, p. 110.

${ }^{79}$ TUCK, The 'modern' theory of natural law, p. 110.

${ }^{80}$ Hugo Grotius, De iure praedae comentarius, I, p. 13. Citado por TUCK, The 'modern' theory of natural law, p. 111.

${ }^{81}$ TUCK, The 'modern' theory of natural law, p. 111.
} 
Ao lidar especificamente com a lei de natureza, Hobbes começa afirmando o que ela não é. Esta é uma forma pouco usual de Hobbes tratar um conceito, pois normalmente o filósofo inicia sua exposição com uma definição explícita, apresentando definições e desenvolvendo raciocínios a partir delas. Nesse ponto, é interessante notar que Hobbes segue o exemplo de Cícero, que em Da república principia a argumentação desenvolvendo o ponto contrário ao seu para, a partir da crítica à definição contrária, chegar à sua própria definição de lei de natureza ${ }^{82}$. Esse não é, de qualquer forma, um método argumentativo criado por Cícero: mesmo Aristóteles, o principal adversário nominal de Hobbes, é conhecido por utilizar o mesmo procedimento, ao começar elencando as diversas opiniões sobre o tema em análise, para então, a partir da crítica a essas opiniões, propor sua própria definição. No tempo de Hobbes, Grócio, como já apontado, viria a repetir o expediente nos prolegômenos de $O$ direito da guerra e da paz, elegendo Carnéades como representante da visão - de que direito é apenas convenção - a ser combatida. E também Locke, que, nos Ensaios sobre a lei de natureza, começa primeiro dizendo como ela não é conhecida pelos homens - mesmo o consenso não garante que ela seja conhecida - para somente depois dar sua própria posição sobre o conhecimento da lei de natureza ${ }^{83}$.

No texto de Hobbes, a lei de natureza é colocada como não sendo o consenso das nações e nem o consenso dos homens. Hobbes se coloca, dessa forma, desde o início contra a tradição ${ }^{84}$ : "[a] teoria do consenso era a mais comum e também a

\footnotetext{
${ }^{82}$ Cf. Cícero, Da república, Livro III, $\S$ V a XIV. Como visto, Cícero coloca na boca de Filão as idéias de Carnéades de que não existe um direito natural, mas apenas o direito convencional.

${ }^{83}$ Cf. Norberto BOBBIO, Locke e o direito natural, pp. 118 a 120.

84 “A definição hobbesiana de lei de natureza (...) difere sensivelmente da concepção oriunda da tradição filosófica do direito e da política inscrita na corrente jusnaturalista" Simone GOYARD-FABRE, Le droit et la loi dans la philosophie de Thomas Hobbes, p. 55.
} 
mais amplamente discutida nas obras dos jusnaturalistas" ${ }^{\wedge 5}$. Aqui, o adversário parece ser especialmente Aristóteles:

enquanto Aristóteles define a lei natural como a 'lei comum' que, fundada no consentimento tácito de todos, possuidora daquela universalidade já assinalada por Empédocles, e que a 'maior parte dos autores' repete, Hobbes garante que a lei de natureza não reside no consensus omnium ${ }^{86}$.

Acerca do primeiro tipo de consenso, o consenso das nações, Hobbes parte do pressuposto de que inexiste acordo entre os que tentaram definir a lei de natureza. Segundo ele, a maior parte dos autores defende que algo é contra a lei de natureza quando "vai contra o consenso de todas as nações, ou contra as nações mais sábias e civilizadas" ${ }^{\$ 7}$. Mas esta opinião da maior parte dos autores está equivocada: "não existe consenso quanto a quem deverá julgar quais nações são as mais sábias" Essa inexistência de acordo indica o que Hobbes refere-se na Epístola dedicatória do livro como saber dogmático:

No segundo [o saber dogmático, não matemático], porém, não existe nada não disputável, porque ele confronta os homens e interfere em seu direito e proveito, nos quais, sempre que a razão estiver contra um homem, estará um homem contra a razão. E daqui decorre que todos aqueles que escreveram sobre a justiça e a sociedade em geral enchem um ao outro, e a si mesmos, de contradição. Para reduzir essa doutrina às regras e à infalibilidade da razão,

\footnotetext{
${ }^{85}$ Norberto BOBBIO, Locke e o direito natural, p. 118.

${ }^{86}$ Simone GOYARD-FABRE, Le droit et la loi dans la philosophie de Thomas Hobbes, pp. 46 e 47. E posteriormente encontra-se a mesma idéia na mesma obra: "Aristóteles, com efeito, funda a lei sobre o consensus omnium". Simone GOYARD-FABRE, Le droit et la loi dans la philosophie de Thomas Hobbes, p. 169.

${ }^{87}$ Elementos, XV, § 1, p. 100 .

${ }^{88}$ Elementos, XV, § 1, p. 100.
} 
não há caminho além de, primeiro, derrubar tais princípios em troca de uma fundação, com a paixão insuspeitada, que não se possa remover; e, em seguida, erguer sobre isso a verdade de casos na lei de natureza (a qual até agora só tem sido construída sobre o ar) passo a passo, até que o conjunto seja irreprimível ${ }^{89}$.

O que Hobbes faz ao negar as concepções tradicionais de lei de natureza é derrubar os tais princípios dogmáticos. A idéia dos autores combatidos é que o que é consensual é natural: se todos pensam o mesmo sobre uma coisa, então essa coisa é (ou deve ser) natural. Hobbes procura assentar o quanto essa generalização é indevida. Contudo, por outro lado, Hobbes não argumenta propriamente contra seus adversários: ele apenas afirma que não há consenso, mas não mostra que ele não exista.

Em relação ao consenso dos homens, Hobbes ressalta que seus defensores, ao contrário do consenso das nações, que não constituem a maioria, "dizem que está contra a natureza aquilo que é contrário ao consenso de toda a humanidade" ${ }^{\text {. }}$. Neste ponto, diferentemente do anterior, o que os autores sustentam é que o consenso é o que está de acordo com a natureza em si - como se lei de natureza e natureza fossem a mesma coisa. A concepção novamente é tomada por Hobbes como inadequada e é imediatamente descartada: "nenhum homem, então, poderia ofender a lei de natureza, pois a natureza de todo homem está contida na natureza da humanidade" ${ }^{91}$. Mas o contra-argumento de Hobbes, neste caso, difere do anterior. É curioso que para dois argumentos semelhantes Hobbes ofereça duas refutações diferentes. Em vez de dizer que lei de natureza não é um consenso da humanidade porque tal consenso não existe (recurso utilizado na argumentação anterior), o contra-argumento agora é o de que, se a

\footnotetext{
${ }^{89}$ Elementos, Epístola dedicatória, p. 18.

${ }^{90}$ Elementos, XV, § 1, p. 100.

${ }^{91}$ Elementos, XV, § 1, p. 100.
} 
lei de natureza fosse o consenso de toda humanidade, então os homens não a ofenderiam. A possibilidade de ofensa atua justamente como prova de que não há consenso.

Na seqüência, o filósofo apresenta outra refutação, que abarca ambos os grupos de autores. Não é o acordo das paixões ou o consenso a respeito de algum erro que cria a lei de natureza, pois, prossegue Hobbes, o homem faz coisas que são contra a lei de natureza pela violência da sua paixão e pelos maus costumes ${ }^{92}$. Aqui não parece ser exatamente uma refutação. Trata-se de uma negação, seguida de uma afirmação. O problema é que a negação não necessariamente exclui a afirmação: o fato do acordo das paixões ou do consenso não criar a lei de natureza não é conseqüência necessária de que os homens desobedecem à lei de natureza em função da força das paixões e dos maus costumes. Outro ponto problemático é que para combater uma generalização (seja o consenso de todas as nações ou o consenso de toda a humanidade) Hobbes apela para outra generalização, ao defender que todo homem, por exemplo, possui maus costumes.

Até esse momento da exposição, Hobbes ainda não definiu o que é a lei de natureza, mas já há bons elementos do que ela não é - ou seja, não é um consenso - e dos motivos pelos quais ela não é um consenso, seja em função da violência das paixões ou dos maus costumes.

A forma com que o filósofo trata inicialmente da questão já indica as dificuldades que a envolvem. Ao começar a exposição dizendo o que a lei de natureza não é, o autor procura deixar bem claro que está indo contra a tradição e contra a opinião corrente sobre o tema. As acepções clássicas ${ }^{93}$ do termo são abandonadas em favor de uma nova definição, obtida a partir do novo método. Esse argumento do

\footnotetext{
92 Elementos, XV, § 1, p. 100.

${ }^{93}$ Que Hobbes identifica, no Diálogo, a Littleton e Edward Coke.
} 
consenso, rejeitado por Hobbes, havia sido utilizado, por exemplo, por Grócio, ao defender que "[n]este ponto [de que a autoconservação seria o fundamento da lei de natureza] os estóicos, os epicuristas e os peripatéticos estão em total acordo, e aparentemente até os acadêmicos participam sem dúvidas" ${ }^{\text {94 }}$. Cícero também se apóia nisso em diversas passagens ${ }^{95}$.

Hobbes nesse ponto parece antecipar a idéia que posteriormente deixaria marcada na introdução do De corpore de que foi ele, e ninguém antes dele, o primeiro a fazer propriamente uma ciência da política ${ }^{96}$.

Entre a refutação das definições tradicionais de lei de natureza e a apresentação da sua própria definição, há um movimento de passagem a ligar os dois momentos. Após afirmar que é a paixão que faz os homens não obedecerem consensualmente à lei de natureza, Hobbes adverte, contudo, que a paixão não está sozinha: o homem não é um ser apenas de paixão, mas também de razão. Tanto a paixão quanto a razão participam da natureza humana ${ }^{97}$, como Hobbes já havia demonstrado no início do seu texto ${ }^{98}$. Mas o que distingue a razão, em relação à paixão, é que ela é a mesma em todos os homens. O motivo para Hobbes concluir isso é o fato de que todos os homens concordam em ser comandados em direção ao bem, que é a principal obra da razão ${ }^{99}$.

\footnotetext{
${ }^{94}$ Hugo GROTIUS, De iure praedae comentarius, I, p. 13. Citado por TUCK, The 'modern' theory of natural law, p. 111.

${ }^{95}$ De oratore, p. 69

${ }^{96}$ De corpore, Epístola dedicatória, p. IX. Edição Molesworth, The English Works of Thomas Hobbes of Malmesbury, Volume I.

${ }^{97}$ A primeira parte dos Elementos chama-se justamente Tratado da natureza humana.

98 "As duas principais partes da nossa natureza, a Razão e a Paixão (...)”. Elementos, p. 17. A esse respeito, "[e]le [Hobbes] acreditava ter construído uma formulação completa de toda a natureza do homem, que poderia ser reduzida a quatro elementos básicos, os poderes naturais do corpo e da mente do homem: força corporal, experiência, razão e paixão". Huntington CAIRNS. Hobbes' theory of law, p. 62. Cf. também Simone GOYARD-FABRE, Le droit et la loi dans la philosophie de Thomas Hobbes, p. 50.

${ }^{99}$ Elementos, XV, § 1, p. 100.
} 
A razão é, afirma Hobbes, considerada igual em todos os homens, sendo assim mais um ponto de igualdade entre eles do que de diferença.

Após discutir o que a lei de natureza não é, Hobbes, seguindo novamente o que havia anunciado na Epístola dedicatória, apresenta sua definição de lei de natureza, a partir da infalibilidade da razão: "[n]ão pode haver, portanto, outra lei de natureza além da razão" ${ }^{100}$; além disso, Hobbes já vincula a razão à busca pela paz: não pode haver também "nem outros preceitos da lei natural do que aqueles que declaram para nós os caminhos para a paz onde esta pode ser obtida e os caminhos para a defesa onde não se puder obtê-la"101.

Chama atenção nessa definição o fato de que Hobbes não procede a uma definição direta do conceito, como usual em seus escritos. O filósofo não afirma o que a lei de natureza é, como seria o esperado, mas apenas diz que ela não pode ser diferente de algo. Hobbes não assevera direta e categoricamente que a lei de natureza é a razão, apesar do sentido indicar precisamente isso. Pois afirmar que algo não é outro senão uma coisa equivale a afirmar que esse algo é essa coisa.

Tem-se bem assentado, dessa forma, que para Hobbes a lei de natureza é a razão, ou ao menos se identifica com ela. Essa definição adquire importância por ser a primeira a ser apresentada, em um momento fundamental do texto. Algo que também se pode concluir acerca dessa definição às avessas é que ela não é direta - se não é possível definir enfaticamente o que é a lei natural, então o filósofo tem que ir tateando as diferentes coisas que ela pode ser. Se Hobbes normalmente é bem explícito em suas definições, aqui ele tergiversa.

\footnotetext{
${ }^{100}$ Elementos, XV, § 1, p. 100.

${ }^{101}$ Elementos, XV, § 1, p. 100.
} 
Definindo lei natural como razão, Hobbes se insere numa longa tradição de autores que fazem a correspondência entre a lei de natureza e a razão. Nomes tão diversos como os de Cícero, d'Alembert, Montesquieu, Santo Agostinho, Santo Tomás, Grócio, Pufendorf, Barberyac, Burlamaqui, Christian Wolff e Achenwall ${ }^{102}$. Entre os contemporâneos de Hobbes, Robert Filmer ${ }^{103}$ dá um tratamento à lei de natureza um tanto diferente da tradição e de seus contemporâneos, sob o aspecto da racionalidade a elas intrínseca. Mesmo evocando uma "lei geral da razão"104, Filmer considera apenas o aspecto da vontade divina ao tratar da lei de natureza, esvaziando-a totalmente de qualquer conteúdo ético ou racional ${ }^{105}$. Combatendo a idéia de que os homens nasceriam livres e disporiam de liberdade para escolher seus governantes, defende que essa idéia contraria a doutrina e a história das Sagradas Escrituras, a prática das antigas monarquias e os "princípios mesmos da lei de natureza"106. Apesar de conceder que "a lei de natureza é imutável"107, o sistematizador da doutrina patriarcalista e do direito divino dos reis ${ }^{108}$ não distingue lei de natureza de lei divina ou mesmo de lei civil - para ele, lei é apenas o fruto da vontade de quem possui autoridade para mandar. No caso específico da lei de natureza, quem a promulga é Deus e "Filmer entende que a lei natural estabelece a autoridade política como derivada de uma concessão divina pessoal"109. Diferente é a posição de John Locke. Apesar de Locke não desenvolver uma teoria da lei de natureza no Segundo tratado sobre o governo, a noção é

\footnotetext{
${ }^{102}$ Simone GOYARD-FABRE, Le droit et la loi dans la philosophie de Thomas Hobbes, pp. 47 e 48.

${ }^{103}$ Filmer, inclusive, pode ser considerado "o primeiro crítico de Hobbes". Cf. Peter Laslett, em nota aos Dois tratados sobre o governo, de John Locke, p. 380.

${ }^{104}$ Sir Robert FILMER, Patriarcha or the natural power of kings, Capítulo III, § 10.

${ }^{105}$ Cf. Maria Cecília Pedreira de ALMEIDA, Escravos, súditos e homens: a noção de consentimento na polêmica Locke-Filmer, dissertação de mestrado, pp. 129 e 130.

${ }^{106}$ Sir Robert FILMER, Patriarcha or the natural power of kings, Capítulo I, § 1.

${ }^{107}$ Sir Robert FILMER, Patriarcha or the natural power of kings, Capítulo II, $\S 6$.

${ }^{108}$ Cf. Maria Cecília Pedreira de ALMEIDA, Patriarcalismo e liberdade: nota sobre a polêmica LockeFilmer, p. 177.

${ }^{109}$ Maria Cecília Pedreira de ALMEIDA, Patriarcalismo e liberdade: nota sobre a polêmica LockeFilmer, p. 184.
} 
extremamente importante no sistema político ali apresentado ${ }^{110}$. Mesmo não definindo expressamente o conceito, Locke o utiliza em momentos importantes da $\operatorname{argumentação~}^{111}$. A lei de natureza é vista, desde o princípio, como razão ${ }^{112}$. A lei de natureza é norma da razão e, portanto, é clara e compreensível para qualquer criatura racional, estando acessível a todos os homens ${ }^{113}$. Contudo, se não determinou uma teoria da lei natural no Segundo tratado, Locke o fez em escritos anteriores, não publicados em vida, agrupados sob o título de Ensaios sobre a lei de natureza. Aqui, pode-se dizer que há propriamente uma teoria sobre a lei natural em Locke. Ou quase isso: os intérpretes defendem que as idéias expostas não são de Locke, mas sim um apanhado das teorias de seu tempo sobre o assunto ${ }^{114}$. Nesses textos, a importância da razão é bem menor do que viria a ocupar no Segundo tratado sobre o governo. Após definir a lei natural como fruto da vontade divina, Locke, "logo em seguida, critica a concepção contrária, a que considera a lei natural não como um comando emanado da vontade divina, mas como um ditame da razão. Sustenta, com efeito, que a razão não pode fundamentar e impor a lei natural, mas apenas descobri-la e interpretá-la"115 ${ }^{\text {. A lei }}$ de natureza é, portanto, primeiro criada pela vontade de Deus, para só depois ser

\footnotetext{
${ }^{110}$ Locke deixa clara a relevância da lei de natureza na compreensão do poder político: “[p]ara entender o poder político corretamente, e derivá-lo de sua origem, devemos considerar o estado em que todos os homens naturalmente estão, o qual é um estado de perfeita liberdade para regular suas ações e dispor de suas posses e pessoas de modo como julgarem acertado, dentro dos limites da lei de natureza, sem pedir licença ou depender da vontade de qualquer outro homem". LOCKE, Dois tratados sobre o governo, p. 382.

${ }^{111}$ A esse respeito, cf. Peter LASLETT, Introdução aos Dois tratados sobre o governo, p. 122.

112 "O estado de natureza tem para governá-lo uma lei de natureza, que a todos obriga; e a razão, em que essa lei consiste, ensina a todos aqueles que a consultem que, sendo todos iguais e independentes, ninguém deveria prejudicar a outrem em sua vida, saúde, liberdade ou posses". John LOCKE, Dois tratados sobre o governo, p. 384.

${ }^{113}$ Cf. John LOCKE, Dois tratados sobre o governo, p. 390.

${ }^{114}$ Cf. Mark GOLDIE, Introdução aos Ensaios políticos, p. XXII, e Norberto BOBBIO, Locke e o direito natural, p. 109.

${ }^{115}$ Norberto BOBBIO, Locke e o direito natural, p. 111.
} 
descoberta pela razão ${ }^{116}$. É uma idéia que já estava germinada nos Dois opúsculos sobre o governo, em que Locke defende que "Deus tornou conhecida Sua vontade pelas descobertas da razão, comumente chamadas de lei de natureza, ou pelas revelações de Sua palavra"117. Ao dar sua posição sobre a possibilidade de conhecimento da lei de natureza, Locke afirma que as coisas - entre elas as leis de natureza - são conhecidas pela razão ou pelos sentidos. E os sentidos e a razão se integram: a razão administra as percepções captadas pelos sentidos. Por eles o homem conhece que há um Deus que a tudo criou e a tudo controla ${ }^{118}$. De forma que, diferentemente do presente no Segundo tratado, nos Ensaios sobre a lei de natureza Locke defende que "a razão não constitui a lei natural (o que não passa de blasfêmia), mas a encontra no mundo ao nosso redor"119. Locke é, por fim, explicitamente contra tratar a lei de natureza como um ditame racional $^{120}$.

Nos Elementos, a definição de lei de natureza como o que não é contrário à razão poderia entrar em conflito com a definição de direito de natureza anteriormente apresentada como aquilo que também não é contra a razão ${ }^{121}$. Os dois conceitos, diferentes, parecem compartilhar a mesma definição. Hobbes afirma diversas vezes que lei e direito são noções opostas - o direito é uma liberdade, ao passo que a lei é uma obstrução a essa liberdade ${ }^{122}$. "A lei natural se distingue fundamentalmente do direito

\footnotetext{
116 “Daí que essa lei de natureza possa ser descrita como decreto da vontade divina discernível pela luz da natureza e indicativo do que está e do que não está em conformidade com a natureza racional, sendo precisamente por essa razão ordenado ou proibido". John LOCKE, Ensaios políticos, p. 102.

${ }^{117}$ John LOCKE, Ensaios políticos, p. 79. Cf. Mark GOLDIE, Introdução aos Ensaios políticos, p. XXI.

${ }^{118}$ Cf. Norberto BOBBIO, Locke e o direito natural, p. 120.

${ }^{119}$ Mark GOLDIE, Introdução aos Ensaios políticos, p. XXIII.

120 "Parece-me menos correto nomeá-la, conforme fazem algumas pessoas, como ditado da razão, já que a razão nem tanto estabelece e pronuncia essa lei de natureza, como a busca e descobre como lei instituída por um poder superior e implantada em nossos corações". John LOCKE, Ensaios políticos, p. 102.

${ }^{121}$ Elementos, XIV, § 6, p 95.

${ }^{122}$ Simone GOYARD-FABRE chama a oposição entre direito, uma liberdade, e lei, uma obrigação, de "uma das linhas de força da construção hobbesiana". Simone GOYARD-FABRE, Le droit et la loi dans la philosophie de Thomas Hobbes, p. 169.
} 
natural, o qual é definido pela liberdade"123. Tal afirmação, entretanto, ajuda a compreender o que Hobbes pretende dizer ao se referir à lei de natureza. Para que sua definição não se confunda com a definição de direito natural, pode-se concluir que a racionalidade não é o termo que define prontamente a lei de natureza, e sim uma de suas qualidades ou características. Lei de natureza não pode ser tomada pura e simplesmente enquanto sinônima de razão, mas sim deve possuir a racionalidade como um de seus atributos principais, aceitando-se, assim, a coexistência com outros atributos, tais quais a origem divina e o caráter moral, como mostrado posteriormente. Esta é a conclusão a que chega Charles Yves Zarka: "compreende-se então que o direito natural e a lei natural podem formar dois ramos de uma alternativa racional que se apresenta a cada homem"124. A relação entre lei de natureza e razão seria, dessa forma, entre o objeto de análise e uma de suas características necessárias. O que abre espaço para outras características constitutivas da lei de natureza. Afinal, ela pode ser também lei divina e lei moral. Assim, é possível concluir que apenas a razão não é capaz de definir exatamente a lei de natureza. A lei de natureza é racional, mas não é sinônima de razão.

Outro ponto ainda a ser mencionado é que, seguindo o caminho aberto por Grócio, Hobbes não faz menção alguma a Deus ao definir a lei de natureza. Certamente uma maneira revolucionária, à época, de se conceber a política ${ }^{125}$.

Logo depois de definir ou identificar a lei de natureza com a razão, Hobbes afirma, como visto anteriormente, que seus preceitos mandam o homem buscar a paz. A paz, para ele, deve ser buscada onde for possível obtê-la; na impossibilidade, os meios de defesa é que devem ser utilizados. O contraste entre guerra e paz está dessa forma implícito: se não é viável a obtenção da paz, então é preciso defender-se por meio

\footnotetext{
${ }^{123}$ Charles Yves ZARKA, Loi naturelle et loi civile chez Thomas Hobbes, p. 63.

${ }^{124}$ Charles Yves ZARKA, Loi naturelle et loi civile chez Thomas Hobbes, p. 63.

${ }^{125}$ Cf. Simone GOYARD-FABRE, Le droit et la loi dans la philosophie de Thomas Hobbes, p. 27.
} 
do seu oposto, a guerra. Aqui fica evidente uma distinção: a diferença entre a lei de natureza e a busca pela paz. Buscar a paz não define a lei de natureza, pois esta é identificada antes com a razão. Buscar a paz é o conteúdo que preenche a lei de natureza, e não a própria lei; é o que a lei de natureza deve objetivar, e não o que ela é.

Hobbes utiliza neste ponto, pela primeira vez, a noção de preceitos da lei de natureza. É possível fazer uma distinção, nem sempre presente nos textos do filósofo (aqui nos Elementos, por exemplo, ela não é explícita), entre a lei de natureza em geral e as leis de natureza em espécie (ou seja, seus preceitos). A lei de natureza em geral equivaleria à razão, enquanto seus preceitos seriam as leis de natureza em espécie, formulando recomendações específicas para que se obtenha o resultado almejado (qual seja, a preservação por meio da paz).

Na seqüência do texto, Hobbes apresenta o primeiro dos preceitos da lei de natureza: "[u]m preceito da lei de natureza, portanto, é este, que Todo homem se desapossa do direito que por natureza tem a todas as coisas"126. Trata-se de uma conclusão extraída a partir das idéias expostas no parágrafo anterior. Como se trata de um preceito da lei de natureza, então se pode supor que se desapossar do direito a todas as coisas é o principal caminho para a paz. Em outras palavras, para conseguir a paz o homem deve abrir mão do seu direito natural a todas as coisas ${ }^{127}$. Esta noção é tão importante que dá o título ao capítulo ${ }^{128}$.

Hobbes justifica que todo homem deve desapossar-se do direito a todas as coisas, pois, se todo homem tem direito a tudo, inclusive aos outros homens, o

\footnotetext{
${ }^{126}$ Elementos, XV, § 2, p. 100. Há, aqui, um problema grave na tradução da Editora Ícone. No original em inglês consta "[f]or when divers men have right not only to all things else, but to one another's persons", traduzido para o português como "[p]ois quando vários homens têm direito não apenas a todas as coisas, mas também às coisas de outrem" (o grifo é nosso). Uma tradução adequada diria que "[p]ois quando diversos homens possuem direito não só a todas as coisas, mas a outras pessoas".

${ }^{127} \mathrm{O}$ direito natural e o estado de natureza são os temas do capítulo imediatamente anterior, Do direito $e$ estado de natureza.

${ }^{128}$ O capítulo XV chama-se Do direito natural desapossado por doação e convenção.
} 
resultado vai ser invasão, resistência e guerra - e guerra é contra a lei de natureza, que determina fazer a paz ${ }^{129}$. Também há uma repetição do conteúdo da lei de natureza, “cuja síntese consiste em fazer a paz"130. A justificativa do preceito já havia aparecido anteriormente em outros termos. A idéia de que o direito a todas as coisas conduz à guerra, tratada no capítulo anterior, tem a forma de um raciocínio silogístico: se o direito a tudo conduz à guerra, e a guerra deve ser evitada, então o direito a tudo deve ser evitado. A seguir, Hobbes desenvolve o tema da renúncia e transferência de direitos, dedicando todo o restante do capítulo a ele.

Seguem-se dois capítulos dedicados às leis de natureza em espécie ${ }^{131}$. Hobbes trata de "algumas leis de natureza"132, e não de todas - o que significa que a lista não é exaustiva, mas sim exemplificativa. Os preceitos da lei de natureza arrolados são, em geral, regras racionais que visam a alcançar a paz. Ao apresentar as leis de natureza em espécie, Hobbes as justifica porque é racional que seu conteúdo sirva para se buscar a paz. A eqüidade, por exemplo, é um preceito da lei de natureza porque é racional que os homens sejam tratados da mesma maneira, pois o contrário gera discórdia ${ }^{133}$.

Não só a racionalidade deve permear as leis de natureza, mas estas obtêm sua força graças a seu caráter racional: "[a] força do comando ou lei de natureza nada mais é do que a força das razões que a ela induzem"134. Ou seja: o que garante a força coativa da lei natural, neste momento, é apenas o seu teor racional. "A lei natural tira

\footnotetext{
${ }^{129}$ Elementos, XV, § 2, p. 100.

${ }^{130}$ Elementos, XV, § 2, p. 100.

${ }^{131}$ Elementos, XVI, Algumas das leis de natureza, e XVII, Outras leis de natureza.

132 Elementos, XVI, p. 107.

${ }^{133}$ Elementos, XVII, § 2, pp. 114 e 115.

${ }^{134}$ Elementos, XVI, § 1, p. 108.
} 


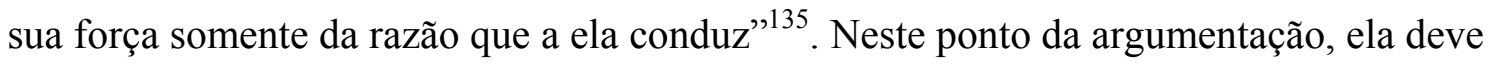
ser obedecida unicamente por ser racional. É importante notar que, no desenvolvimento do sistema hobbesiano, essa idéia é abandonada, como visto logo a seguir.

Após enumerar as leis de natureza em espécie, Hobbes tece algumas considerações sobre a lei de natureza em geral ${ }^{136}$. É surpreendente que essas observações ocupem tal lugar no texto: o esperado seria que estivessem na parte que trata de lei natural em geral, e não das leis de natureza em especial. Hobbes pode tê-las alocado aqui pois requerem que se saiba quais são os preceitos da lei de natureza para compreendê-las, ou então para resolver dúvidas que possam ter sido suscitadas durante a exposição das leis de natureza em espécie.

Encontra-se, entre essas considerações, uma das idéias mais controvertidas da filosofia de Hobbes e, no chamado "caso da lei natural", uma das passagens que vem recebendo o maior número de tentativas de explicação:

E visto que a lei, falando propriamente, é um comando, e estes ditames, por procederem da natureza, não são comandos, só podem portanto ser chamados de leis não no que respeita à natureza, mas no que respeita ao autor da natureza, Deus Todo-Poderoso ${ }^{137}$.

Nesta passagem, Hobbes deixa claro que a lei de natureza tomada apenas como preceito da razão não é exatamente uma lei. Hobbes havia definido a lei anteriormente como uma espécie do gênero comando: é a espécie de comando que tem em si a razão suficiente para a ação ${ }^{138}$. E o comando como um gênero entre as expressões de intenção

\footnotetext{
${ }^{135}$ ZARKA, Loi naturelle et loi civil chez Thomaz Hobbes, p. 62.

${ }^{136}$ Elementos, a partir do $\S 9$ do capítulo XVII.

${ }^{137}$ Elementos, XVII, $\S 12$, p. 118.

${ }^{138}$ Cf. Elementos, XIII, § 6, p. 90.
} 
e de vontade dentro dos usos da linguagem. A teoria de Hobbes a esse respeito pode ser expressa conforme a seguinte tabela:

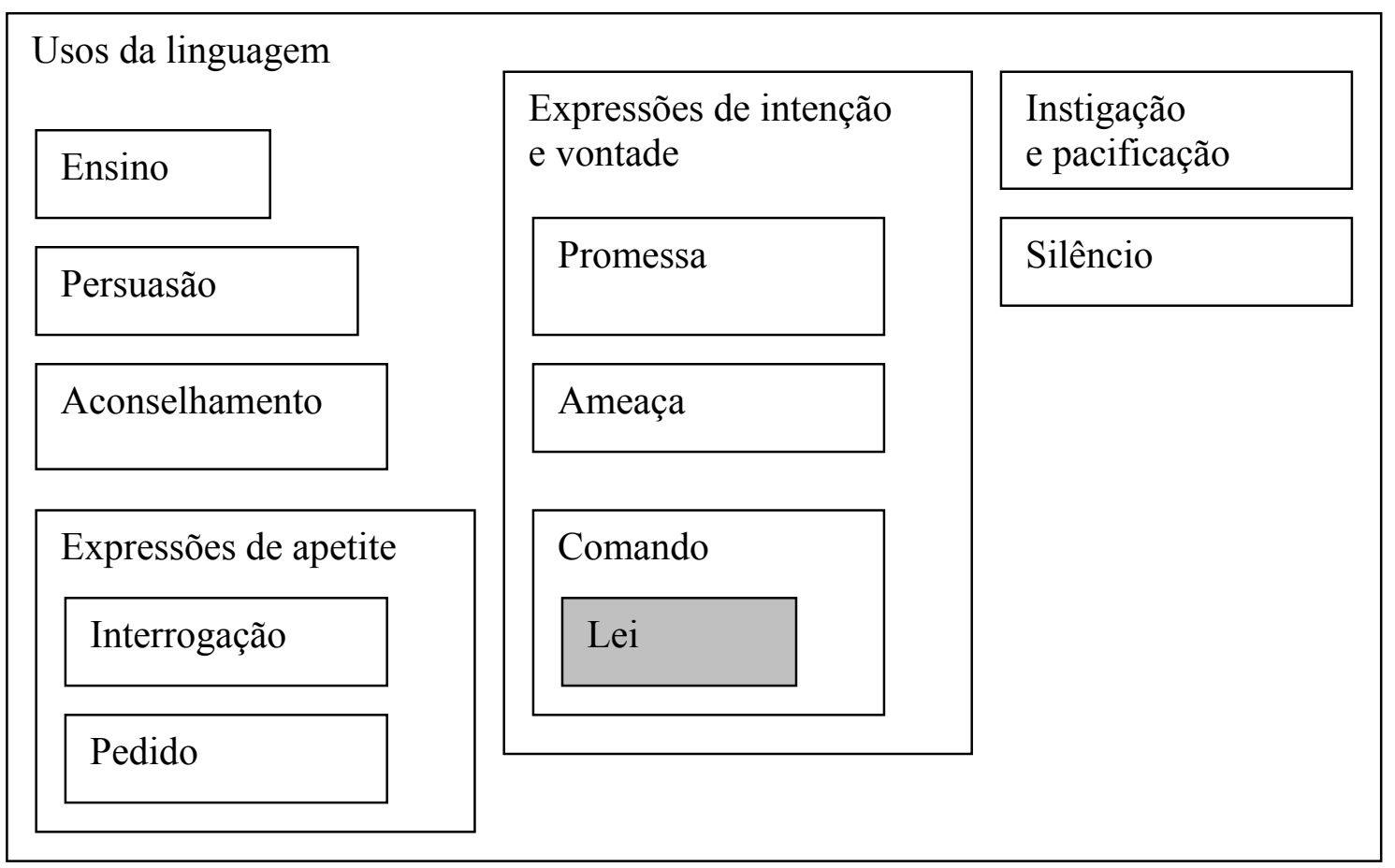

Uma lei em sentido próprio, ou seja, um comando, precisa ter sido determinada por alguém com poder para tanto. No caso específico das leis de natureza, por Deus. Por outro lado, essas mesmas leis, vistas como provenientes da natureza, não são leis em sentido estrito. Para Hobbes, é por ser oriunda da natureza que a lei natural não é um comando, já que a lei propriamente dita é sempre um comando dado por quem tem condições de comandar. $\mathrm{O}$ aspecto racional, que há pouco bastava à lei de natureza para dar-lhe "força de comando" "139, agora se mostra insuficiente para que ela cumpra sua missão de dar paz aos homens. Nesse sentido, a lei de natureza "é simplesmente um cálculo e um conselho da razão; ela não é uma norma jurídica; ela não é nem mesmo uma regra imperativa, mas sim uma tendência e mesmo uma 'qualidade' da natureza

${ }^{139}$ Elementos, XVI, § 1, p. 108. 
humana"140. Não sendo precisamente uma norma, Hobbes afasta-se da tradição jusnaturalista que o precedeu, para quem a lei de natureza como regra racional seria uma lei propriamente dita ${ }^{141}$.

Um outro ponto importante é o fato de a lei natural como razão dizer respeito à consciência. Não é, contudo, uma inovação trazida por Hobbes - a mesma idéia já está presente em toda a tradição jusnaturalista ${ }^{142}$. Por proceder da natureza e ser racional, a lei de natureza pode ser infringida não só no plano externo da ação, mas ainda no plano interno da razão.

E visto que as leis de natureza dizem respeito à consciência, elas são violadas não apenas por aqueles que realizam uma ação contrária a elas, mas também por aqueles cujas ações lhes são conformes a elas enquanto que o seu pensamento lhes é contrário. Pois embora ocorra de a ação ser correta (right), em seu juízo, porém, ele menospreza a lei ${ }^{143}$.

Aqui, Hobbes deixa claro, não obstante, que a lei de natureza não é apenas menoscabada no plano da consciência, mas também no da ação.

Posteriormente, há uma passagem que pode causar estranhamento. Hobbes defende que um homem, ao obedecer às leis, está de acordo com sua própria consciência, mas não de acordo com sua consciência particular.

E embora seja verdade que o que quer que um homem faça contra a sua consciência é um pecado, ainda assim a obediência, nestes casos, não é nem pecado, nem é contra

\footnotetext{
${ }^{140}$ Simone GOYARD-FABRE, Le droit et la loi dans la philosophie de Thomas Hobbes, p. 49.

141 "Hobbes parece acolher a tradição que lhe antecede, quando nomeia aqueles ditames da reta razão como 'leis de natureza', mas o faz a contragosto, porque elas não se inserem na sua definição do termo". Marcelo Gross VILLANOVA, Lei natural e lei civil na filosofia política de Thomas Hobbes, p. 33.

${ }^{142}$ Marcelo Gross VILLANOVA, Lei natural e lei civil na filosofia política de Thomas Hobbes, p. 38.

${ }^{143}$ Elementos, XVII, § 13, pp. 118 e 119.
} 
a obediência [sic! problema da tradução: o termo correto é consciência; no original consta conscience]. Pois a consciência, sendo nada mais que o julgamento e a opinião afirmados de um homem, uma vez que ele transfere a outrem o seu direito de julgar, que aquilo deverá ser comandado, é não menos o seu julgamento do que o julgamento daquele outro. De modo que na obediência às leis um homem ainda está de acordo com sua própria consciência, mas não com sua consciência particular ${ }^{144}$.

Haveria então uma distinção entre a consciência do homem e sua consciência particular. A consciência particular seria a que está presente na razão de cada homem individual. Já a consciência própria é a que o homem transfere ao soberano, abrindo mão do seu julgamento privado sobre as coisas do mundo, para ganhar em troca a paz e a conservação. Com isso, cada homem teria duas consciências, por vezes coincidentes (quando o seu julgamento é o mesmo daquele do soberano) e por vezes destoantes (quando seu julgamento difere daquele do soberano). No caso de conflito, para Hobbes quem deve prevalecer é sempre a consciência do soberano.

Como visto, nos Elementos fica bem determinado que a lei de natureza tem como principal atributo a característica racional, o que não implica que o conceito esteja definitivamente delimitado nela nem tampouco que sejam certas quais as conseqüências decorrentes dessa característica racional.

Do cidadão foi publicado por Hobbes em 1642, pouco tempo depois que os Elementos circularam em forma de manuscrito pela Inglaterra. A obra foi estruturada para ser a última parte do sistema geral de filosofia de Hobbes, uma trilogia intitulada Elementos de filosofia. Além de Do cidadão, viriam a formar posteriormente os

\footnotetext{
${ }^{144}$ Elementos, Parte II, VI, § 12, p. 185.
} 
Elementos de filosofia a primeira parte - o De corpore, ou Do corpo ou Sobre o corpo e a segunda - o De homine, ou Do homem ou Sobre o homem ${ }^{145}$. Hobbes explica, no prefácio de Do cidadão, o motivo que o impeliu a começar a publicação de seu sistema pela parte derradeira: a emergência de uma guerra civil em função da grave situação política inglesa à época ${ }^{146}$. Em função disso, Hobbes precisa lidar com um problema metodológico. Ele afirma em determinados pontos ${ }^{147}$ que sua filosofia política prescinde de sua física e metafísica (expressas no De corpore) e de sua antropologia (expressa no De homine); mas, a justificar a publicação precipitada de Do cidadão, defende que a política pode sem prejuízo ser compreendida sem seus fundamentos físicos, metafísicos e antropológicos ${ }^{148}$.

Como nos Elementos, em Do cidadão a lei natural enquanto preceito da razão recebe uma formulação mais direta e mais forte do que as concepções de comando divino e de lei moral, além de ser também a primeira a aparecer. Já no prefácio, ao apresentar o plano da obra, Hobbes adianta que as leis de natureza são ditados da razão:

Ademais, declaro e confirmo em que consiste a natureza dos pactos, como e por que meios o direito de um pode ser transferido a outro a fim de validar os pactos; e que direitos, e a quem devem necessariamente ser concedidos para se estabelecer a paz. Quero dizer: quais são os ditados

\footnotetext{
${ }^{145}$ Acerca de seu projeto filosófico, Hobbes escreve: "na primeira [parte] trataria do corpo, e de suas propriedades gerais; na segunda, do homem e de suas faculdades e afecções especiais; na terceira, do governo civil e dos deveres dos súditos". Do cidadão, p. 17.

146 “Aconteceu, nesse ínterim, que meu país, alguns anos antes que as guerras civis se desencadeassem, já fervia com questões acerca dos direitos de dominação, e da obediência que os súditos devem, questões que são as verdadeiras precursoras de uma guerra que se aproxima; e isso foi a causa para que (adiando todos os demais tópicos) amadurecesse e nascesse de mim esta terceira parte". Do cidadão, p. 18.

${ }^{147}$ Por exemplo nos Elementos, p. 19.

148 "Assim sucede que aquilo que era último na ordem veio a lume primeiro no tempo, e isso porque vi que esta parte, fundada em seus próprios princípios suficientemente conhecidos pela experiência, não precisaria das partes anteriores". Do cidadão, p. 18. Cf. também Simone GOYARD-FABRE, Le droit et la loi dans la philosophie de Thomas Hobbes, p. 16.
} 
da razão, que podem com propriedade ser denominados leis de natureza ${ }^{149}$.

Não há, contudo, maiores desenvolvimentos nesse ponto.

O direito de natureza também é determinado como algo de acordo com a razão ${ }^{150}$, como já havia sido expresso nos Elementos $^{151}$ :

Ora, aquilo que não contraria a reta razão é o que todos os homens reconhecem ser praticado com justiça e direito; pois, pela palavra direito, nada mais se significa do que aquela liberdade que todo homem possui para utilizar suas faculdades naturais em conformidade com a razão reta ${ }^{152}$.

Inicialmente, pode-se atentar que a razão, aqui, não define o direito natural, mas sim o limita: o homem pode fazer o que quiser, desde que não contrarie a razão. Além disso, uma diferença em relação aos Elementos é que aqui não é simplesmente a razão que qualifica o direito, mas sim a reta razão. A diferença entre razão e reta razão foi tratada de modo diferente por Hobbes nos dois livros. Nos Elementos o autor rejeita expressamente que exista a reta razão ${ }^{153}$, trabalhando apenas com uma noção genérica de razão. Essa concepção foi alterada em Do cidadão, em que Hobbes aceita e emprega a existência de uma reta razão.

\footnotetext{
${ }^{149}$ Do cidadão, p. 16.

${ }^{150}$ Do cidadão, I, 7, p. 31.

${ }^{151}$ Elementos, XIV, § 6, p. 95.

${ }^{152}$ Do cidadão, p. 31.

${ }^{153}$ Tratando da medida comum a ser determinada pela lei civil, Hobbes defende, nos Elementos, que "nestas coisas particulares, os homens diferem e geram controvérsia. Esta medida comum, alguns dizem, é a reta razão. Com os quais eu devo concordar, se houver alguma coisa a ser encontrada ou conhecida in rerum natura. Mas comumente aqueles que chamam pela reta razão a fim de decidir alguma controvérsia, fazem o seu próprio método. Porém, visto que a reta razão não existe, é certo que a razão de algum homem ou alguns homens deve suplantar o lugar daquela; e que este homem ou estes homens são aqueles que detêm o poder soberano, conforme já ficou provado". Elementos, parte II, capítulo X, § 8, p. 215.
} 
Se no primeiro capítulo, que trata de estado de natureza, não há nada especificamente sobre lei natural, no segundo Hobbes começa - assim como nos Elementos - discutindo o que a lei de natureza não é.

Depois de defender que a lei de natureza não é o consenso das nações e da humanidade ${ }^{154}$, praticamente como nos Elementos, o filósofo aponta que tanto o justo quanto o direito é o que não contraria a razão ${ }^{155}$. A idéia de direito como razão já havia aparecido antes, como visto. Essa posição é alterada, no entanto, no Leviatã, conforme tratado em local próprio.

Após Hobbes dizer o que a lei natural não é, ele a define justamente como ditame da reta razão:

Por conseguinte, assim defino a lei de natureza: é o ditame da reta razão no tocante àquelas coisas que, na medida de nossas capacidades, devemos fazer, ou omitir, a fim de assegurar a conservação da vida e das partes de nosso corpo $^{156}$.

Ela é o ditame da reta razão, com um conteúdo bem específico, que determina o que se deve fazer para se conservar. Novamente é encontrada a noção de reta razão, ausente nos Elementos. O próprio Hobbes incumbe-se de explorar melhor o significado do conceito, em uma nota:

Por reta razão no estado da natureza humana, não entendo (como querem muitos), uma faculdade infalível, porém o ato de raciocinar - isto é, o raciocínio peculiar e verdadeiro acerca daquelas suas ações que possam resultar em detrimento ou benefício de seus próximos ${ }^{157}$.

\footnotetext{
${ }^{154}$ Do cidadão, p. 37.

${ }^{155}$ Do cidadão, p. 37.

${ }^{156}$ Do cidadão, p. 38.

${ }^{157}$ Do cidadão, p. 361.
} 
A diferença entre as obras reside, a princípio, apenas na terminologia: se Hobbes não aceita a existência de uma razão infalível, o que ele chama de reta razão em Do cidadão corresponde ao que ele chama simplesmente de razão nos Elementos. Contudo, nos Elementos parece que o uso que cada homem faz da razão é incapaz de, por si só, livrálo da condição de discordância com os demais. Assim sendo, para sanar tal fato, faz-se necessária a instituição de outra razão, a do soberano. Ao passo que, em Do cidadão, a reta razão parece ser capaz de incluir os outros homens no cálculo, tornando-se assim menos relativa. Ou seja, nos Elementos o homem parece utilizar a razão apenas para seu próprio benefício, enquanto que em Do cidadão a reta razão é usada também em função do "detrimento ou benefício de seus próximos". Se tal raciocínio estiver correto, podese compreender a diferença na terminologia $\operatorname{adotada}^{158}$.

Em relação aos Elementos, há algumas diferenças significativas no conceito de lei de natureza. A mais notável é que agora a definição é colocada de maneira direta. O autor não diz o que não pode deixar de ser a lei natural, mas sim afirma categoricamente o que ela é. Lei de natureza é o ditame da reta razão. Importante não perder de vista que a lei de natureza não é a reta razão, mas sim o(s) ditame(s) obtido(s) a partir dela. Além disso, Hobbes mantém a característica racional, mas coloca na própria definição a conservação da vida e do corpo. Com isso, escapa da objeção anteriormente apresentada, a de que somente a razão não bastaria para definir a lei de natureza. Ou seja, a lei de natureza não abarca tudo o que é racional (pois Hobbes afirma também que o direito natural é racional), mas apenas aquilo que se refere à conservação da vida. A lei de natureza aparece não apenas como reta razão, mas como

\footnotetext{
${ }^{158}$ Há diferença também em relação à concepção cartesiana de razão: "esse preceito essencialmente prático [a reta razão hobbesiana] não é, como diz Descartes, a marca de Deus na criatura; ele se inscreve na 'marcha' geral da razão, como o 'primeiro passo' de uma teleologia antropológica". Simone GOYARD-FABRE, Le droit et la loi dans la philosophie de Thomas Hobbes, p. 48.
} 
um ditame da reta razão com um conteúdo específico. Observa-se, bem claramente, como Hobbes foi refinando sua teoria de um texto para outro.

A seguir, como nos Elementos, o filósofo enumera as leis específicas de natureza. A primeira, aqui também chamada de fundamental, manda buscar a paz. Não há menção explícita à razão no enunciado da lei, mas em sua explicação encontra-se a afirmação de que este "preceito é ditado pela reta razão"159. A explicação do conteúdo é assim novamente dada em função de seu caráter racional. Hobbes deixa claro também que, por ser racional, desse primeiro preceito todos os demais são derivados. A lei de natureza é sempre definida como ditames oriundos da reta razão: “[a]cabamos de provar que os ditados da reta razão constituem leis naturais" ${ }^{\text {"160 }}$.

Nos Elementos, depois da definição da lei de natureza, todas as outras leis são tratadas como pertencentes a um mesmo gênero, não havendo distinção expressa entre uma lei geral ou fundamental e as leis derivadas ou especiais. Já em Do cidadão há diferença. Depois de enunciar a lei natural fundamental, Hobbes apresenta o que chama de "primeira lei especial de natureza""161, que manda abrir mão do direito natural a todas as coisas. Na sua enunciação não há menção à razão, mas ao retomar o assunto o filósofo assevera que contrariar essa primeira lei especial de natureza é ir contra a razão, ou seja, contra a lei de natureza ${ }^{162}$.

Após explicitar as primeiras leis de natureza, é realizada uma longa exposição sobre contratos e transferência de direitos - mais uma vez como nos Elementos - importante para justificar o que Hobbes defende na seqüência sobre o modo racional de se obter a paz. Há, nessa apresentação, uma nota em que o filósofo

\footnotetext{
${ }^{159}$ Do cidadão, p. 38.

${ }^{160}$ Do cidadão, p. 38.

${ }^{161}$ Do cidadão, p. 39.

${ }^{162}$ Do cidadão, p. 39.
} 
postula que infringir as leis de natureza é raciocinar falsamente, o que está de acordo com sua definição de reta razão apresentada pouco antes ${ }^{163}$.

A seguir, Hobbes descreve as outras leis especiais de natureza. Mas não faz referência à razão. Eventualmente considera lei de razão como sinônimo de lei natural $^{164}$, mas sem maiores desdobramentos na argumentação.

Depois de enunciar as leis naturais em espécie, o filósofo realiza, ecoando os Elementos, considerações sobre elas. Nessas considerações, novamente encontra-se presente a afirmação de que a lei natural obriga sempre apenas no plano da consciência: "[d]evemos pois concluir que a lei de natureza sempre e em toda a parte obriga em foro interno, ou na corte da consciência, mas nem sempre em foro externo, e neste apenas quando puder ser cumprida com segurança"165. A lei de natureza deveria, se possível, ser vinculante tanto no plano da consciência como no plano da ação. Entretanto, o autor deixa claro que no plano da ação, ainda na condição natural, tal exigência é inviável, pois não há condições nem garantias de que os demais a cumprirão "e portanto quem cumprir a lei se tornará presa fácil de quem a viola"166. Como a autoconservação é o postulado básico de todo o sistema, Hobbes rejeita de plano que o homem se torne presa fácil ${ }^{167}$, acarretando com isso a rejeição também da exigência de cumprimento da lei natural no estado de natureza.

\footnotetext{
${ }^{163}$ Do cidadão, p. 361.

${ }^{164}$ Por exemplo, na décima quarta e na vigésima leis.

${ }^{165}$ Do cidadão, p. 70.

${ }^{166}$ Do cidadão, p. 70.
}

${ }^{167}$ Interessante perceber que em Maquiavel já se encontra o argumento de que os homens se unem em sociedades para evitar tornarem-se presa fácil dos demais: “[o] primeiro caso [de edificação das cidades] ocorre quando os habitantes, dispersos em muitas e pequenas partes, percebem que não poderão viver seguros, visto que cada um por si não poderia resistir ao ímpeto de quem os assaltasse, seja pelas feições do local, seja por serem em pequeno número, e não teriam tempo de unir-se para defesa diante da chegada do inimigo; os mesmos, em havendo tempo, precisariam abandonar muitos de seus redutos, vindo assim a tornar-se presa fácil dos inimigos: de tal modo que, para escaparem a esses perigos, movidos por si mesmos ou por alguém dentre eles com mais autoridade, se reúnem para morar juntos, em lugar escolhido por eles, lugar que seja mais cômodo para se viver e mais fácil de se defender". Discursos sobre a primeira década de Tito Lívio, livro I, cap. I, p. 8. 
Ainda nas considerações gerais sobre as leis de natureza após a enumeração dos seus preceitos em espécie ${ }^{168}$, há novamente a noção de que, por serem apenas conclusões racionais, elas não são propriamente leis:

Contudo, o que denominamos lei de natureza, como nada mais são que certas conclusões entendidas pela razão, acerca das coisas que devem ser feitas ou omitidas - ao passo que uma lei, para falar de maneira própria e acurada, é o discurso de quem tem o direito de mandar que façam ou deixem de fazer determinadas coisas -, a bem dizer elas não são leis, dado que procedem da natureza. Porém, na medida em que são outorgadas por Deus nas Sagradas Escrituras - como veremos no capítulo seguinte - é muito apropriado chamá-las pelo nome de leis: pois a Sagrada Escritura é o verbo de Deus mandando, pelo maior de todos os direitos, sobre todas as coisas ${ }^{169}$.

O trecho é importantíssimo. Fundamentalmente, é uma idéia que já havia sido desenvolvida nos Elementos, ou seja, de que a razão não torna a lei de natureza obrigatória. Se a lei é um comando, e a lei de natureza enquanto ditame racional não é comando, mas sim conclusão de um raciocínio, então a lei de natureza não é propriamente uma lei. O problema não é que ela não desfruta do estatuto de lei, mas sim que, destituída de sua imperatividade, ela mostra-se inoperante. Se ela não pode constranger, ela não serve para muita coisa, valendo somente enquanto guia ou oráculo. Não passa de preceito prudencial ${ }^{170}$. A lei de natureza como preceito racional mostra-se destituída de efetividade: "[a] partir da antropologia hobbesiana, segundo a qual a

\footnotetext{
${ }^{168}$ No capítulo III do livro.

${ }^{169}$ Do cidadão, p. 74.

${ }^{170}$ Norberto BOBBIO, Thomas Hobbes, p. 39.
} 
natureza humana é determinada por paixões violentas e belicosas, sem a existência e a força coercitiva da lei civil, a lei natural permanece ineficaz"171.

A própria linguagem de Hobbes, a respeito da obrigatoriedade da lei de natureza, é bastante escorregadia nesse ponto. Ora o filósofo afirma que as leis de natureza “ordenam" (a nona lei de natureza em espécie ${ }^{172}$ ) e “determinam” (a décima lei de natureza em espécie ${ }^{173}$ ), ora diz que elas apenas concluem (a quarta lei de natureza em espécie ${ }^{174}$ ). Além disso, se as leis naturais silenciam no estado de natureza ${ }^{175}$ (eis que elas levariam os homens a se tornarem presa fácil dos demais), elas não devem ser comandos (não podendo ser aplicada aqui uma fórmula do tipo no Estado civil usa-se a lei civil, da mesma forma que no estado de natureza usa-se a lei de natureza).

Os comentadores divergem. Como coloca Martinich,

[o] fato de que a obrigação não é parte do conteúdo da lei suscita a questão 'por meio de qual autoridade as leis de natureza são leis?'. Esta é talvez a questão menos resolvida e mais ferozmente discutida entre os estudiosos de Hobbes. A interpretação dominante é que a razão comanda as leis de natureza. Dado que a razão não é uma pessoa e só pessoas podem genuinamente comandar alguma coisa, segue-se que as leis de natureza não são genuinamente leis. No Leviatã [e nos demais livros], Hobbes diz que os 'ditames da razão' não são propriamente chamados de leis, e isso é muitas vezes tido

\footnotetext{
${ }^{171}$ Maria das Graças de SOUZA, Apresentação, p. 9. In: Lei natural e lei civil na filosofia política de Thomas Hobbes, de Marcelo Gross VILLANOVA. A mesma idéia, defendendo que as leis naturais são válidas mas não eficazes, está presente em Norberto BOBBIO, Thomas Hobbes, p. 40.

${ }^{172}$ Do cidadão, capítulo III, p. 63.

${ }^{173}$ Do cidadão, capítulo III, p. 63.

${ }^{174}$ Do cidadão, capítulo III, p. 60.

${ }^{175}$ Cf. Do cidadão, capítulo V, p. 91.
} 
como um equivalente à asserção de que as leis de natureza não são adequadamente chamadas de leis ${ }^{176}$.

Defendendo que as leis naturais não são vinculantes, temos, para Celso Lafer, que "as leis da natureza, em Hobbes, não são verdadeiramente leis, mas se reduzem à racionalidade do homem e à sua capacidade de definir o que é útil"177. E também B. Barry: “as leis de natureza não constituem obrigações para os homens, no sentido primordial de 'obrigação' que é empregado no Leviatã'"178. Rita Helena Sousa Ferreira Gomes também partilha a posição de que a lei natural não é obrigatória, dada sua natureza de preceito da razão: "[d]efini-la conselho significa, portanto, retirar dela seu caráter obrigatório e dar-lhe caráter prudencial do tipo: se queremos $\mathrm{X}$, e temos a esperança de obtê-lo, devemos fazer $\mathrm{Y}^{, 179}$. A obrigação, se existe, é apenas de consciência, não estando presente no plano das ações - no que Hobbes afasta-se da tradição jusnaturalista, que considerava as leis naturais como obrigações incondicionais $^{180}$.

E, por outro lado, na posição de que a lei natural é uma regra que tem força imperativa, temos S. Moore: “[a] verdadeira doutrina das leis de natureza é a verdadeira filosofia moral, segundo Hobbes; porque as leis de natureza são idênticas à lei moral. Sua abordagem em relação à ética é revelada em sua definição de lei natural" " . E após citar a definição de Hobbes de lei natural: "[d]e acordo com esta definição, uma lei de natureza tem três características: ela é uma regra geral de conduta;

\footnotetext{
176 A. P. MARTINICH, Thomas Hobbes: A biography, p. 147.

${ }^{177}$ Celso LAFER, Hobbes, o Direito e o Estado Moderno, p. 31.

${ }^{178}$ B. BARRY, Warrender and his critics, p. 188.

${ }^{179}$ Rita Helena Sousa Ferreira GOMES, Lei natural e lei civil em Hobbes, p. 148.

${ }^{180}$ Cf. Rita Helena Sousa Ferreira GOMES, Lei natural e lei civil em Hobbes, p. 149.

${ }^{181}$ S. MOORE, Hobbes on obligation, moral and political. Part one: moral obligation, p. 224.
} 
ela é descoberta pela razão; e ela deriva sua força imperativa do instinto de autoconservação" ${ }^{\prime 182}$.

Relativizando (ou seja, assumindo que a lei natural é tratada como comando ora sim, ora não), há a posição defendida por Trainor: "Hobbes deixa bem claro que as leis de natureza só podem ser consideradas leis em sentido estrito quando elas são reconhecidas como leis divinas"183.

Assim, como visto, em linhas gerais a questão é tratada em Do cidadão da mesma maneira que nos Elementos: Hobbes identifica a lei de natureza aos preceitos da razão, mas deixa claro que isso não constitui elemento suficiente para que ela seja cumprida com segurança.

O Leviatã é considerado geralmente o apogeu da filosofia de Hobbes ${ }^{184}$. Foi escrito na França, enquanto Hobbes encontrava-se no exílio, e publicado na Inglaterra em 1651. Na época, o parlamento inglês colocava-se contra o rei Charles Isituação extremamente insegura para Hobbes, partidário do rei. Tentando interferir na situação política inglesa, Hobbes acabou circulando, em menos de 11 anos, sua obra política com fundamentalmente as mesmas idéias em três diferentes versões (com os Elementos em 1640, Do cidadão em 1642 e o Leviatã em 1651) ${ }^{185}$.

No Leviatã, diferentemente das outras obras, a lei natural como recomendação racional aparece somente quando Hobbes trata do estado de natureza ${ }^{186}$, não havendo nenhum esclarecimento prévio a esse respeito. Há um capítulo inteiro

\footnotetext{
${ }^{182}$ S. MOORE, Hobbes on obligation, moral and political. Part one: moral obligation, p. 225.

${ }^{183}$ B. T. TRAINOR, Hobbes on political allegiance and obligation. p. 232.

${ }^{184}$ Simone GOYARD-FABRE, Le droit et la loi dans la philosophie de Thomas Hobbes, p. 13.

${ }^{185}$ Simone GOYARD-FABRE, Le droit et la loi dans la philosophie de Thomas Hobbes, pp. 15 e 16.

${ }^{186}$ Leviatã, Capítulo XIII.
} 
dedicado à razão ${ }^{187}$, definida como cálculo, mas não é feita nenhuma menção à lei de natureza.

A lei natural como preceito racional aparece subitamente na própria definição de lei de natureza. No Leviatã, Hobbes repete essa primeira definição em dois momentos: no final da exposição sobre o estado de natureza ${ }^{188}$ e no início das discussões sobre lei de natureza ${ }^{189}$. Em ambos os trechos a lei de natureza é definida como regras sugeridas pela razão para preservação do homem.

No primeiro desses momentos, que trata do estado de natureza, o autor afirma que o homem pode sair da condição de guerra em função de suas paixões e de sua razão. É exatamente a razão que fornece normas para que se obtenha a paz:

E a razão sugere adequadas normas de paz, em torno das quais os homens podem chegar a um acordo. Essas normas são aquelas a que em outras ocasiões se chamam leis de natureza, das quais falarei mais particularmente nos dois capítulos seguintes $^{190}$.

Hobbes define aqui a lei de natureza como normas de paz sugeridas pela razão, pelas quais os homens podem chegar a um acordo.

Em relação às outras obras, há algumas alterações. Em primeiro lugar, como em Do cidadão e diferentemente dos Elementos, é uma definição direta. No Leviatã, tanto quanto em Do cidadão, a lei de natureza não é identificada diretamente com a razão, mas sim definida como as normas que são dadas pela razão. A lei de natureza, então, não é mais a razão, mas sim as normas dadas por ela: “[n]os Elementos, ele [Hobbes] define a lei de natureza como razão simpliciter. No De cive, ele enfraquece

\footnotetext{
${ }^{187} \mathrm{O}$ capítulo $\mathrm{V}$.

${ }^{188}$ Leviatã, capítulo XIII, p. 111.

${ }^{189}$ Leviatã, capítulo XIV, p. 112.

${ }^{190}$ Leviatã, capítulo XIII, $\S 14$, p. 111.
} 
perceptivelmente a definição e diz que a lei de natureza é um ditado da razão. No Leviatã, a definição torna-se muito mais complicada [como visto no momento oportuno] e é a mais sensata"191. Com esse artifício, Hobbes consegue escapar de objeções que poderiam ser colocadas sobre o caráter meramente racional da lei de natureza - lei de natureza não é sinônimo de razão, e sim é constituída por normas racionais. Não são normais racionais quaisquer, mas normas racionais que visam à paz. Também é importante ser destacado que as normas da razão, ou seja, a lei natural, não são ordenadas, mas sim sugeridas, o que afasta, ao menos no uso da linguagem, seu caráter de obrigatoriedade.

No capítulo seguinte, sobre as leis de natureza, o filósofo começa definindo direito natural e liberdade, para só então lidar com a lei natural.

Hobbes chega, enfim, à definição expressa de lei de natureza, tratando-a justamente em termos de preceito da razão:

Uma LEI DE NATUREZA (Lex Naturalis) é um preceito ou regra geral, estabelecido pela razão, mediante o qual se proíbe a um homem fazer tudo o que possa destruir a sua vida ou privá-lo dos meios necessários para a preservar, ou omitir aquilo que pense melhor contribuir para a preservar $^{192}$.

Em primeiro lugar, observa-se que aqui a lei de natureza é tomada enquanto um preceito ou regra geral. Por mais que os termos possam comportar diferentes sentidos em relação à obrigatoriedade, o uso que Hobbes dá a eles é

\footnotetext{
${ }^{191}$ A. P. MARTINICH, Hobbes: a biography, p. 146.

${ }^{192}$ Leviatã, capítulo XIV, § 3, p. 112.
} 
destituído de imperatividade ${ }^{193}$. O preceito ou regra geral, aqui, indica mais uma recomendação do que uma ordem.

Esse preceito, ou essa regra geral, é estabelecido, para Hobbes, pela razão. Com isso se acentua o caráter de recomendação, em detrimento do sentido de ordem ou comando, pois uma ordem pode ser sem razão, mas uma orientação ou explicação do funcionamento de algo não pode. Aproxima-se cada vez mais a noção de demonstração, de recomendação, e afasta-se a idéia de ordem ou comando imperativo. Se a lei de natureza é racional, ela é um cálculo de efeitos ou conseqüências a partir de causas ou princípios, mas não um comando.

A lei de natureza, avança Hobbes, prescreve que o homem não deve fazer coisas que possam destruir sua vida ou atentar contra sua preservação. É, assim, um ditame racional com um conteúdo determinado. O sentido aqui é negativo: é proibido ir contra a vida. O filósofo não defende que se deve ir a favor dela. No fim das contas, se a conseqüência pode ser a mesma, por que Hobbes não determinou que essa regra manda agir a favor da vida ou da preservação? Uma explicação possível é porque a lei, ou regra, tem o caráter de proibição, de dar limites, mais do que o caráter de permissão, como é justificado exatamente na seqüência, ao diferenciar lei de direito. Leo Strauss fornece uma outra interpretação para esse caráter negativo da prescrição. Para ele, Hobbes prefere, surpreendentemente, a expressão negativa evitar a morte à expressão positiva preservar a vida

porque nós sentimos a morte e não a vida; porque nós tememos a morte imediata e diretamente, enquanto nós desejamos a vida apenas porque a reflexão racional nos diz que ela é a condição de nossa felicidade; porque nós

\footnotetext{
193 Como presente, por exemplo, em Leviatã, XV, § 41, p. 137. Esta passagem é objeto de análise no próximo item da presente dissertação.
} 
tememos a morte infinitamente mais do que desejamos a vida $^{194}$.

Logo após a definição de lei de natureza, Hobbes apresenta a primeira lei de natureza em espécie, em termos também de preceito racional:

Conseqüentemente, é um preceito ou regra geral da razão: Que todo homem deve se esforçar pela paz, na medida em que tenha esperança de a conseguir, e caso não a consiga pode procurar e usar todas as ajudas e vantagens da guerra. A primeira parte desta regra encerra a primeira e fundamental lei de natureza, isto é, procurar a paz, e seguila. A segunda encerra a súmula do direito de natureza, isto é, por todos os meios que pudermos, defendermo-nos a nós mesmos ${ }^{195}$.

É uma formulação bem mais sofisticada e complicada do que a presente nas demais obras. Acerca desse preceito primeiro e fundamental, nota-se que a lei de natureza é uma conseqüência do estado de natureza, o que destaca mais uma vez seu caráter racional. Sendo racional, a razão consiste justamente em tirar conseqüências de determinadas causas.

Hobbes repete nesse ponto a formulação de lei natural como preceito ou regra geral da razão, utilizando exatamente os mesmos termos empregados na definição.

Essa primeira lei da natureza não é novidade no Leviatã, pois ela estabelece que o homem deve se esforçar pela paz. E isso já está na própria definição de lei de natureza enquanto regra racional para autopreservação. Só que antes ela era dada negativamente ${ }^{196}$, proibindo fazer algo contra a preservação, ao passo que aqui ela é esboçada positivamente, mandando agir pela paz. Entendem-se paz e preservação como

\footnotetext{
${ }^{194}$ Leo STRAUSS, The political philosophy of Hobbes, p. 16.

${ }^{195}$ Leviatã, capítulo XIV, § 4, p. 113.

${ }^{196}$ Leviatã, XIV, § 3, p. 112.
} 
praticamente sinônimas, já que uma não existe sem a outra - para a preservação da vida e dos membros é necessária a paz, como tinha sido afirmado no parágrafo anterior. $\mathrm{O}$ fato de a lei natural ser dada positivamente nessa passagem, contendo não uma proibição, mas um mandamento, algo que deve ser feito, vai mais de acordo com a definição de lei, que coloca obstáculos à liberdade natural. Essa face positiva do conteúdo da lei de natureza é a principal inovação do trecho.

Esse preceito, prossegue o filósofo, é a primeira e fundamental lei da natureza. Fundamental na medida em que praticamente repete a definição de lei natural. Como é fundamental, vai servir de base para as demais. É o ponto de partida, o axioma, o postulado, do qual todas as outras são derivadas. Vê-se, aqui, a aplicação do método geométrico de tirar conseqüências a partir de primeiros princípios irrefutáveis. Se ela é a lei fundamental, então se pode supor que existem outras que não são fundamentais. Há, portanto, dois tipos de lei de natureza: a lei fundamental, que faz parte da própria definição e que alimenta e informa as demais, e as leis não fundamentais, que são derivadas dessa primeira.

Em relação aos Elementos, e emulando o Do cidadão, também são observadas algumas inovações em relação ao mandamento de se buscar a paz:

No geral, seu [de Hobbes] tratamento para as leis de natureza no De cive e no Leviatã é muito mais sofisticado do que no seu trabalho político anterior. Nos Elementos, a determinação para buscar a paz parece ser a lei geral de natureza. Nos outros dois trabalhos, 'buscar a paz' expressa apenas a primeira lei de natureza, da qual as outras serão deduzidas ${ }^{197}$.

${ }^{197}$ A. P. MARTINICH, Hobbes: a biography, p. 146. 
Há, nesse ponto, também uma inovação em relação aos autores da tradição jusnaturalista. Se para Hobbes o fim da lei natural é a paz, para a tradição é o bem $^{198}$. Mesmo que na história da filosofia a lei natural tenha abarcado princípios bastante diferentes entre $\mathrm{si}^{199}$, as leis de natureza poderiam ser consideradas pela tradição “[u]m corpo de regras prescritivas (em oposição a descritivas), tratando da conduta humana, capaz de serem descobertas por todos os homens de reta razão, e superior à lei positiva dos Estados individuais"200. Já “[a]s leis de natureza hobbesianas não se encaixam nessa definição" ${ }^{201}$. Elas são, a princípio, destituídas de conteúdos expressos, sendo formadas por regras abstratas para se obter a paz, podendo-se afirmar, portanto, que "Hobbes inovou ao fazer a lei natural (e os direitos naturais) formal em caráter"202. Os conteúdos específicos das leis de natureza devem ser preenchidos, como visto em local próprio, pelas leis civis.

Essa regra geral da razão descrita por Hobbes possui duas partes. Uma é a lei fundamental e primeira da natureza e a outra é a súmula do direito natural. Assim, como nas demais obras, observa-se que tanto a lei natural como o direito natural estão submetidos à razão. É um tanto estranho pensar que o direito natural está numa regra, se ele seria justamente o seu contrário, a liberdade a ser tolhida pela regra. Essa súmula do direito natural, "defendermo-nos por todos os meios que pudermos", corresponde bem ao que tinha sido exposto sobre o direito de natureza ${ }^{203}$. Ele atua apenas na ausência das condições de validade da lei de natureza - quando esta não pode ser aplicada, lança-se mão do direito de natureza. Ou seja, não há incompatibilidade entre lei natural e direito

\footnotetext{
${ }^{198}$ Norberto BOBBIO, Thomas Hobbes, p. 105.

${ }^{199}$ Howard WARRENDER, Obligations end rights in Hobbes, p. 155.

${ }^{200}$ Howard WARRENDER, Obligations end rights in Hobbes, p. 155.

${ }^{201}$ Howard WARRENDER, Obligations end rights in Hobbes, p. 155.

${ }^{202}$ Howard WARRENDER, Obligations end rights in Hobbes, p. 155.

${ }^{203}$ Leviatã, XIV, § 1, p. 112.
} 
natural - este atua apenas quando ou onde aquela calar, ou seja, quando ela não puder ser eficazmente cumprida. Caso o homem consiga permanecer vivo sem matar ninguém, que assim seja; mas, caso sua sobrevivência dependa da morte de outros homens, isso é plenamente aceitável. No fim das contas, o que interessa mesmo à Hobbes é a autopreservação. Lançar mão da lei de natureza ou do direito de natureza são instrumentos, cada um a ser usado numa situação própria, para que o homem garanta sua sobrevivência.

O filósofo refere-se à esperança. Se houver esperança, o homem deve procurar a paz; se não houver, deve se defender com todos os meios que conseguir. É uma construção semelhante à presente em Do cidadão. A esperança é, conforme apresentado anteriormente, uma das paixões para evitar a condição de guerra.

Nessa definição, há uma diferença em relação ao texto presente em Do cidadão, no qual a lei fundamental não era a primeira lei em espécie, mas sim a lei geral, ficando mais evidente uma distinção nos dois tipos de lei natural.

Avançando, Hobbes apresenta no parágrafo seguinte a segunda lei:

Desta lei fundamental de natureza, mediante a qual se ordena a todos os homens que se esforcem para conseguir a paz, deriva esta segunda lei: Que um homem concorde, quando outros também o façam, e na medida em que tal considere necessário para a paz e para a defesa de si mesmo, em resignar ${ }^{204}$ ao seu direito a todas as coisas, contentando-se, em relação aos outros homens, com a

\footnotetext{
${ }^{204}$ A revisora técnica, Eunice Ostrensky, alterou aqui a tradução na nova edição lançada pela Martins Fontes Editora. Na tradução original, publicada na coleção Os pensadores e de autoria de João Paulo Monteiro, a opção é por renunciar. Ela substituiu por resignar: é para evitar a confusão que aparece logo depois entre renúncia propriamente dita e renúncia numa situação especial (com isso há dois termos para dois conceitos, renúncia e resignação).
} 
mesma liberdade que aos outros homens permite em relação a si mesmo ${ }^{205}$.

No trecho, Hobbes repete mais uma vez a primeira e fundamental lei da natureza. Aqui ela aparece como "lei fundamental da natureza, mediante a qual se ordena a todos os homens que se esforcem para conseguir a paz". Importante notar que aqui ela ordena. Trata-se de uma ordem, um comando, um mandamento, e não uma recomendação ou orientação.

Essa segunda lei só vale enquanto for considerada necessária para a paz e a preservação. É, por isso, derivada da primeira lei.

O homem precisa concordar com essa segunda lei natural, mas não sozinho, pois os outros também precisam. Hobbes justifica isso, na medida em que não adianta um homem abrir mão dos seus direitos a tudo se os outros também não fizerem, pois ele torna-se, como já desenvolvido nos Elementos, presa fácil dos demais.

A seguir, no mesmo parágrafo Hobbes explica essa segunda lei:

Porque enquanto cada homem detiver o seu direito de fazer tudo quanto queira todos os homens se encontrarão numa condição de guerra. Mas se os outros não resignarem ao seu direito, assim como ele próprio, não há razão para que alguém se prive do seu, pois isso equivaleria a oferecer-se como presa (coisa a que ninguém é obrigado), e não a dispor-se para a paz. É esta a lei do Evangelho: Faz aos outros o que queres que te façam a ti. E esta é a lei de todos os homens: Quod tibi fieri non vis, alteri ne feceris $^{206}$.

\footnotetext{
${ }^{205}$ Leviatã, XIV, § 5, p. 113.

${ }^{206}$ Leviatã, $\S 5$, p. 113. A lei dos homens pode ser traduzida como "não faça aos outros o que não deseja que seja feito a você".
} 
O início também não é novo - Hobbes já havia afirmado que o direito a fazer tudo leva a uma situação de guerra. Relevante observar aqui que são apresentadas as leis do Evangelho e de todos os homens. Mas o filósofo ainda não explica em que elas consistem.

Como nas outras obras, Hobbes passa a tratar longamente de contratos, importantes para depois engendrarem o contrato social ${ }^{207}$.

No capítulo seguinte, são enumeradas as leis de natureza em espécie. Curioso o fato de que Hobbes não utiliza a noção de preceito racional a respeito delas nessa enunciação, centrando-se mais no aspecto de busca pela paz. No final do capítulo, da mesma forma que nos Elementos e em Do cidadão, o filósofo faz considerações sobre lei de natureza em geral.

Entre essas considerações gerais sobre lei de natureza, é somente o último ponto que trata de lei natural como preceito da razão. É uma passagem complicada, semelhante à das demais obras, que causa grande celeuma entre os intérpretes:

A estes ditames da razão os homens costumam dar o nome de leis, mas impropriamente. Pois eles são apenas conclusões ou teoremas relativos ao que contribui para a conservação e defesa de cada um, enquanto a lei, em sentido próprio, é a palavra daqueles que tem o direito de mando sobre os outros. No entanto, se considerarmos os mesmos teoremas como transmitidos pela palavra de Deus, que tem direito de mando sobre todas as coisas, nesse caso serão propriamente chamados leis ${ }^{208}$.

\footnotetext{
${ }^{207}$ Expressão que o filósofo não utiliza.

${ }^{208}$ Leviatã, XV, § 41, p. 137.
} 
Ao se analisar a passagem, pode-se observar, em primeiro lugar, que Hobbes parte da lei de natureza enquanto ditame da razão. Além disso, tais ditames são, segundo o próprio autor, chamados comumente de leis, inclusive por ele. São chamados de lei, mas impropriamente, pois ditame da razão não participa da definição de lei dada anteriormente. A definição apresentada agora para lei natural é a mesma - a de lei natural como conclusões ou teoremas para a conservação e preservação (não há problema em dizer que ditames da razão são conclusões ou teoremas). Isso se diferencia da definição dada por Hobbes de lei, pois lei, em sentido próprio, é a palavra daquele que tem direito de mando sobre os outros, e conclusão racional não é palavra de mando. Não sendo palavra de mando, a lei de natureza como ditame racional não é lei. Não sendo lei, não pode ser exigido seu cumprimento: "as leis de natureza são regras para a orientação da consciência, ou fórum interno, mas não obrigam que se aja conforme a elas"209. É apenas uma sugestão, uma recomendação.

No restante do livro, Hobbes faz alusões esparsas, afirmando, por exemplo, que leis não podem ir contra a razão, mas não mais do que isso ${ }^{210}$. Ao tratar das leis civis, na perspectiva de que elas só podem ser obedecidas se publicadas, Hobbes profere que é o aspecto racional que determina a lei de natureza:

Em primeiro lugar, se for uma lei obrigatória para todos os súditos sem exceção, e não estiver escrita ou de algum outro modo publicada em lugares onde se possam informar, trata-se de uma lei de natureza. Porque tudo o que os homens conhecem como lei, não pelas palavras de outros homens, mas cada um através da sua própria razão, deve ser válido para a razão de todos os homens, o que não pode acontecer com nenhuma lei, a não ser a lei de

\footnotetext{
${ }^{209}$ Marcelo Gross VILLANOVA, Lei natural e lei civil na filosofia política de Thomas Hobbes, p. 41.

${ }^{210}$ Leviatã, XXVI, § 11, p. 230.
} 
natureza. Portanto, as leis de natureza não precisam ser públicas nem proclamadas, pois estão contidas nesta única sentença, aprovada por toda gente: Não faças aos outros o que não considera razoável que seja feito por outrem a ti mesmo $^{211}$.

Essa lei civil, para ser válida, deve ser lei natural. É importante na medida em que Hobbes afirma que o que os homens conhecem como lei por meio da sua própria razão é a lei de natureza. Interessante perceber que aqui a lei de natureza é assim identificada em função de ter validade consensual (pois é o que todos os homens consideram racional), argumento rejeitado pelo filósofo anteriormente.

Dessa maneira, observa-se que o tratamento dispensado por Hobbes à lei de natureza acompanha, sem grandes mudanças, as considerações presentes nas demais obras sistemáticas de filosofia política. Lei natural enquanto norma ditada pela razão, mas não desfrutando plenamente do estatuto de lei.

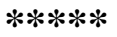

Além do conteúdo presente nas três obras mais sistemáticas de Hobbes que tratam de política, o filósofo também lida com o tema da lei de natureza num texto tardio, incompleto e publicado apenas postumamente. Trata-se do Diálogo entre um filósofo e um jurista ${ }^{212}$. Em linhas gerais, a obra pode ser vista como um desdobramento da teoria da soberania de Hobbes, com sua aplicação ao caso especial dos julgamentos nos tribunais e da autonomia dos juristas: de fato, “a teoria geral do Diálogo é meramente uma aplicação da doutrina do Leviatã no caso específico da common law.

\footnotetext{
${ }^{211}$ Leviatã, XXVI, § 12, p. 231.

${ }^{212}$ É o título da única edição em português. Será chamado, doravante, de Diálogo. O original inglês é $A$ dialogue between a philosopher and student of Common Laws of England, que, traduzido ao pé da letra, seria Um diálogo entre um filósofo e um estudioso do direito comum da Inglaterra. A respeito da tradução desse título, cf. Renato JANINE RIBEIRO, Prefácio a Diálogo entre um filósofo e um jurista, p. 9.
} 
Não há desenvolvimento na teoria"213. Hobbes defende que a fonte e a aplicação da lei devem residir no soberano, e apenas no soberano, combatendo expressamente a visão de Littleton e de Sir Edward Coke ${ }^{214}$ de que o direito teria origem nas decisões emanadas pelos juízes, nos precedentes, nos costumes ${ }^{215}$ e nas posições doutrinárias dos juristas. Havia, na época de Hobbes, grande conflito entre os juristas e o rei para determinar em quem estaria o fundamento do direito. O rei James I, inclusive, tentou simplificar as leis e a linguagem jurídica, sofrendo oposição tanto do parlamento como da classe dos juristas $^{216}$. O texto pode ser visto, portanto, como uma tomada de posição no debate, com Hobbes posicionando-se claramente ao lado do rei e contra a common $\operatorname{law}^{217}$ : “[d]iz com toda a clareza que a lei é o que o soberano edita - ou seja, sua concepção é romana, não consuetudinária"218.

Apesar do tempo que separa a confecção das obras (os três textos sistemáticos datam da década de 1640 e início dos anos 1650; o Diálogo foi redigido ao final da vida de Hobbes, provavelmente na década de 1670, e publicado postumamente em 1681), a concepção de Hobbes acerca da lei de natureza permaneceu essencialmente inalterada. Ela é vista sobremaneira como lei de razão, com algumas alusões à lei divina.

\footnotetext{
${ }^{213}$ Huntington CAIRNS, Hobbes' theory of law, p. 80.

${ }^{214}$ As Tenures, de Littleton, foram comentadas por Coke em seus Institutes. Já foram publicadas aproximadamente 115 edições da obra de Littleton (noventa das quais sem os comentários de Coke), que constituiu por mais de três séculos parte fundamental da educação jurídica na Inglaterra, sendo até hoje citada nos tribunais.

${ }^{215}$ A idéia de que a lei é o costume da comunidade é medieval - é a noção de que "a lei é a expressão do hábito de vida da comunidade". Huntington CAIRNS, Hobbes' theory of law, p. 74.

${ }^{216}$ Cf. Renato JANINE RIBEIRO, Prefácio a Um diálogo entre um filósofo e um jurista, p. 17.

${ }^{217}$ A common law, ou direito comum, é normalmente traduzida para o português como direito costumeiro ou direito consuetudinário. De caráter medieval, o direito costumeiro era formado por regras imemoriais que determinavam como se deveria agir em cada situação, com importância imensa do precedente (o costume como apurado e depurado pelos juízes nas decisões dos tribunais). A esse respeito, cf. Renato JANINE RIBEIRO, Prefácio a Um diálogo entre um filósofo e um jurista, pp. 10, 14 e 15.

${ }^{218}$ Renato JANINE RIBEIRO, Prefácio a Um diálogo entre um filósofo e um jurista, p. 18.
} 
Tanto que o primeiro capítulo da obra traz como título Sobre a lei da razão. O plano do capítulo é precisar que tipo de razão é associada à lei humana e à lei

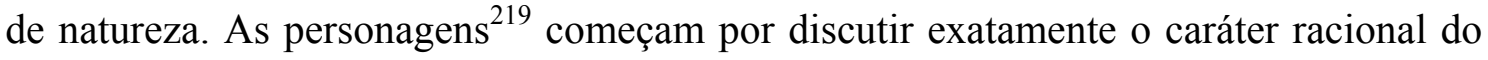
estudo do direito. Apesar da distância entre as duas posições, ambos estão de acordo em que a lei de natureza é lei de razão. A respeito dos Tenures, de Littleton, afirma o filósofo: “[c]onfesso ter encontrado nesse livro grande sutileza, não da lei, mas sim das inferências a partir da lei, e sobretudo a partir da lei da natureza humana, que é a lei da

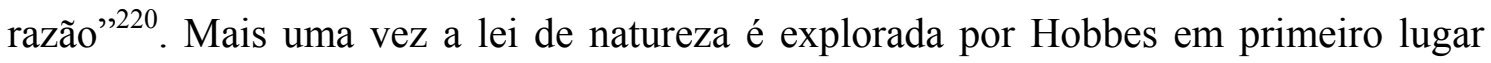
como preceito oriundo da razão. Em comparação com as concepções presentes nas outras obras, parece haver o mesmo conteúdo. Todavia, o texto aqui é levemente diferente. Em primeiro lugar, porque não se trata aqui da lei de natureza, mas sim da lei da natureza humana. Em segundo lugar, que essa lei da natureza humana não é pura e simplesmente a razão, mas sim a lei da razão. Hobbes não desenvolve o sentido preciso desses termos, pois aqui ainda está determinando o que Littleton e Coke escreveram sobre o tema. E o filósofo continua concordando, nesse primeiro ponto, com a posição desses autores, deixando expresso que pensa como Coke que "a razão é a alma do Direito (...), ou seja, nada do que é contrário à razão é direito; e a razão é a vida do Direito e mais ainda, o próprio Direito comum nada mais é senão razão" ${ }^{221}$. Aqui, uma afirmação familiar às outras obras de Hobbes, na medida em que o direito é tido como o que não pode ser contrário à razão. Antes de formular suas objeções, o filósofo ainda cita uma passagem de Coke com a qual está de acordo: “[a] eqüidade é uma certa razão

\footnotetext{
${ }^{219}$ São duas as personagens, ambas sem nome e identificadas apenas pela profissão: um filósofo e um jurista. Via de regra (mas com algumas exceções, como nos $\S \S 17$ e 19) o filósofo defende a posição de Hobbes e o jurista expõe e defende as posições de Littleton comentadas por Coke. Sobre isso, cf. Renato JANINE RIBEIRO, Prefácio a Um diálogo entre um filósofo e um jurista, p. 26. M. M. GOLDSMITH considera que a obra encontrava-se inacabada por "algumas passagens estarem atribuídas ao personagem errado". M. M. GOLDSMITH, Hobbes on law, p. 274.

${ }^{220}$ HOBBES, Um diálogo entre um filósofo e um jurista, pp. 35 e 36.

${ }^{221}$ HOBBES, Um diálogo entre um filósofo e um jurista, p. 36.
} 
perfeita que interpreta e altera a lei escrita, sendo ela própria não escrita e composta de nada mais que a razão certa"222. A eqüidade, nos outros livros posta como uma das leis de natureza em espécie, aqui é vista como uma razão certa, perfeita e não escrita que interpreta e altera a lei escrita.

Dessas idéias o filósofo confessa não discordar, não obstante deixaremno perplexo. O motivo: "porque isso torna inoperantes todas as leis do mundo"223. Por quê? "Pois com base nisso qualquer homem poderá dizer que qualquer lei é contrária à razão, e a partir daí ter um pretexto para desobedecer",224.

O jurista tenta resolver o impasse, afirmando que a razão jurídica “deve ser entendida como uma perfeição artificial da razão que foi adquirida com longo tempo de estudo, observação e experiência; e ao da razão natural de todos os homens; pois nemo nascitur artifex" ${ }^{225}$. Seria essa razão artificial dos juristas, para o estudioso das leis, a própria summa ratio, a reta razão.

Com tal posição o filósofo não pode concordar: “[i] sso não esclarece a passagem, pois é em parte obscuro e em parte falso" 226 . A razão, para ele, não pode de maneira alguma ser artificial - ela deve ser sempre natural. Mesmo sabendo que o conhecimento do direito é obtido somente com muito estudo, isso não faz da razão artificial, pois é a própria razão natural que obtém o conhecimento. Apesar de estar de acordo em que o direito é uma arte, o filósofo defende que não é a arte, por melhor que seja, que faz o direito: "[o] que faz uma lei não é a sabedoria, e sim a autoridade"227. Aqui está o núcleo do argumento de Hobbes. Hobbes deixa clara nesse ponto a

\footnotetext{
${ }^{222}$ HOBBES, Um diálogo entre um filósofo e um jurista, p. 36.

${ }^{223}$ HOBBES, Um diálogo entre um filósofo e um jurista, p. 36.

${ }^{224}$ HOBBES, Um diálogo entre um filósofo e um jurista, p. 36.

${ }^{225}$ HOBBES, Um diálogo entre um filósofo e um jurista, p. 36. O ditado latino pode ser traduzido por "ninguém nasce dominando uma arte".

${ }^{226}$ HOBBES, Um diálogo entre um filósofo e um jurista, p. 37.

${ }^{227}$ HOBBES, Um diálogo entre um filósofo e um jurista, p. 37.
} 
diferença que deve haver entre a lei humana, fundada na autoridade de quem possui poder de mando, e a lei natural, fundada na razão. Ambas não podem ser confundidas. Apesar de todos serem criaturas racionais, e a lei de natureza reportar-se à razão, Hobbes não pode admitir que haja mais de uma razão prescrevendo as leis civis que governam as ações dos súditos. Isso geraria pluralidade de mando e, como conseqüência, sedições, tumultos e ausência de paz. O filósofo acentua que não se pode aceitar a existência de mais de uma espécie de razão: “[o]bscuras são também as palavras 'razão jurídica': nas criaturas terrenas não há razão outra que não a razão humana" 228 . Só há uma razão, que é a razão natural e a razão humana. O filósofo nega que a razão dos juízes sem o rei seja a summa ratio e a verdadeira lei, pois só pode fazer lei quem tem o poder legislativo (isto é, o rei). É o que ele conclui na seqüência:

[é] claramente falso que a lei tenha sido depurada por homens graves e doutos, ou seja, os professores de Direito, pois todas as leis da Inglaterra foram feitas pelos reis da Inglaterra, que consultaram a nobreza e os comuns do Parlamento, onde em vinte homens não se encontra um único jurista douto ${ }^{229}$.

Em suma, Hobbes defende aqui que o que faz a lei (civil) é a autoria do rei, e não a razão. O texto combate os juristas em prol do rei: tudo pela unidade do poder.

O jurista vê-se obrigado a concordar com o filósofo, havendo um breve momento de harmonia entre eles. O jurista afirma que "a essas leis da razão todo súdito, que esteja em pleno juízo, está obrigado a prestar atenção por sua conta e risco, porque a razão faz parte da sua natureza e o acompanha continuamente, e ele pode consultá-la, se assim quiser",230 , recebendo em apoio do filósofo a afirmação de que "a razão é o Direto

\footnotetext{
${ }^{228}$ HOBBES, Um diálogo entre um filósofo e um jurista, p. 37.

${ }^{229}$ HOBBES, Um diálogo entre um filósofo e um jurista, p. 37.

${ }^{230}$ HOBBES, Um diálogo entre um filósofo e um jurista, p. 38.
} 
comum"231. Após isso, ambos enveredam por uma discussão a respeito da finalidade das leis escritas.

A partir da discussão sobre a finalidade das leis, Hobbes mais uma vez repete que os ditames da razão devem sempre visar à preservação do homem. O jurista, neste ponto específico ecoando a posição não de Coke, mas do próprio Hobbes, afirma que sem a lei qualquer um pode fazer o que bem entender. E que sem a lei tudo é de todos. "Pois os ditames da razão pouco valem se não atenderem à preservação e à melhoria da vida dos homens" ${ }^{, 232}$. Mas se com ou sem leis humanas todos acabariam brigando, “a mesma lei da razão dita à humanidade, para sua própria preservação, uma distribuição de terras e bens, a fim de que cada homem saiba o que lhe cabe e assim ninguém mais possa pretender um direito sobre aquilo ou perturbá-lo no seu uso"233. Pouco após:

[é] também um ditame da lei da razão que as leis estatutárias são um meio necessário da segurança e do bem-estar do homem no mundo presente, e devem ser obedecidas por todos os súditos, como deve ser obedecido pelo rei e pelos súditos a lei da razão, porque é a lei de Deus $^{234}$.

É a razão, convertida em lei, que determina as regras pelas quais os homens poderão viver em relativa harmonia.

Da discussão sobre a finalidade das leis os debatedores passam ao tema da efetividade da lei, a ser encontrada na força soberana do rei. Aqui, voltam a discutir o caráter racional da lei. Afirma novamente o jurista que a reta razão "é uma perfeição

\footnotetext{
${ }^{231}$ HOBBES, Um diálogo entre um filósofo e um jurista, p. 38.

${ }^{232}$ HOBBES, Um diálogo entre um filósofo e um jurista, p. 42.

${ }^{233}$ HOBBES, Um diálogo entre um filósofo e um jurista, p. 42.

${ }^{234}$ HOBBES, Um diálogo entre um filósofo e um jurista, p. 42.
} 
artificial da razão adquirida por estudo, observação e experiência, aos quais se dedicou longo tempo, e não uma razão natural do homem"235. Posição que o filósofo volta a rechaçar, desta vez com ironia: “[o] senhor acha que isso é boa doutrina? Embora seja verdade que ninguém nasce com o uso da razão, todos podem atingi-la, inclusive os juristas" ${ }^{236}$. A summa ratio, mais uma vez o filósofo adverte, só pode ser a razão do rei. Com o que se aproximam os conceitos de lei de razão e lei humana: "aquela eqüidade, sobre a qual todos concordam ser a lei da razão, é tudo o que, fora a Bíblia, é ou em algum tempo foi lei na Inglaterra, desde que esta se tornou cristã",237.

E uma terceira vez o filósofo nega uma multiplicidade da razão frente ao jurista.

O senhor gostaria que os homens alegassem mutuamente como lei sua razão particular? Entre os homens não existe uma razão universal sobre a qual há acordo dentro da nação, além da razão daquele que tem o poder soberano. Contudo, a razão deste, embora não passe da razão de um homem, está estabelecida para ocupar o lugar dessa razão universal, que o Salvador nos expõe no Evangelho, e conseqüentemente o nosso rei é para nós o legislador da lei estatutária, assim como do Direito comum ${ }^{238}$.

Aqui fica patente uma insuficiência da lei de razão. Se ela não é a mesma para todos os homens, não pode ser aplicada como pacificadora social. Deve-se recorrer, para tanto, a uma lei que seja a mesma para todos - não a razão de cada um, mas a razão de um terceiro, o soberano civil. É de uma incompletude da lei de natureza vista como lei de razão que surge a necessidade da lei humana. O jurista aceita a explicação:

\footnotetext{
${ }^{235}$ HOBBES, Um diálogo entre um filósofo e um jurista, p. 46.

${ }^{236}$ HOBBES, Um diálogo entre um filósofo e um jurista, p. 47.

${ }^{237}$ HOBBES, Um diálogo entre um filósofo e um jurista, p. 47.

${ }^{238}$ HOBBES, Um diálogo entre um filósofo e um jurista, p. 54.
} 
[s]im, sei que as leis espirituais, que têm sido leis neste reino desde a abolição do papismo, são as leis do rei, assim como as que foram feitas antes; pois os cânones da Igreja de Roma não foram lei nem aqui nem em lugar algum, fora os domínios temporais do papa, enquanto os reis e os Estados em seus vários domínios não os converteram em tal ${ }^{239}$.

Disso o filósofo, como esperado, não discorda. Acrescenta que eventualmente os reis fazem leis com ajuda e anuência dos nobres, mas que isso não é necessário.

Pode-se dizer, por fim, que no Diálogo, apesar de não haver a sistematicidade das demais obras, a teoria por trás das discussões é plenamente compatível com a filosofia hobbesiana exposta nos outros textos. A lei de natureza é formada a partir de recomendações da razão, com vistas à preservação da vida do homem.

\section{Interpretações da lei natural como preceito racional}

Entre os leitores e comentadores de Hobbes, até o início do século XX a única interpretação discutida a respeito das leis de natureza era em função de seu caráter racional. Isso demonstra a importância da noção. Serviu inclusive como argumento usado por Skinner, em polêmica com Warrender, a diminuir a importância do comando divino enquanto característica determinante da lei de natureza ${ }^{240}$.

Contrariamente ao que normalmente sempre se supôs, defende Skinner que Hobbes foi tomado como autoridade no tema da lei de natureza pelos seus contemporâneos e pelos intérpretes imediatamente posteriores, em especial no

\footnotetext{
${ }^{239}$ HOBBES, Um diálogo entre um filósofo e um jurista, p. 54.

${ }^{240}$ Cf. SKINNER, The ideological context of Hobbes's political thought, p. 313.
} 
continente, como Lambertino Velthuysen, E. Mertlat, J. W. Textor e J. C. Beckman, mas também na Inglaterra, como no caso de Daniel Scargill ${ }^{241}$. Mesmo os adversários de Hobbes, como Clarendon e outros moralistas cristãos, criticavam-no por fundamentar a política não nas leis divinas, mas na "razão auto-interessada"242. Para seus contemporâneos, a necessidade de obedecer à lei de natureza em Hobbes decorre exclusivamente da necessidade de autopreservação. Se ela vem mesmo do comando de Deus (como querem Taylor ou Warrender), então todos os seus contemporâneos - mui estranhamente, assinala Skinner - não perceberam isso: "[t]odos eles [os contemporâneos de Hobbes] citavam Hobbes como a autoridade que havia demonstrado que os fundamentos e a necessidade dessa obrigação [a obrigação política] residia no desejo preeminente de auto-preservação"243. Mesmo a condenação de Hobbes, em 1683, pela Universidade de Oxford como autor de livros contra a ortodoxia foi fundamentada na atribuição de que é o auto-interesse a lei fundamental da natureza, que supera todas as outras instâncias ${ }^{244}$.

Mais recentemente, a interpretação que considera as leis de natureza apenas como preceitos da razão ainda é a mais comum e preponderante ${ }^{245}$. É a visão tradicional sobre a filosofia hobbesiana, pela qual os homens concordam, por ser racional, em submeter-se a um terceiro para que melhor consigam assegurar sua sobrevivência. Apenas a recomendação dada pelo cálculo racional (como expressão da lei de natureza) é suficiente, de acordo com essa visão, para os homens saírem do estado de natureza em direção ao Estado civil. Nela enquadram-se alguns dos principais

\footnotetext{
${ }^{241}$ Cf. SKINNER, The ideological context of Hobbes's political thought, p. 312.

${ }^{242}$ Cf. SKINNER em The ideological context of Hobbes's political thought, p. 315.

${ }^{243}$ SKINNER, The ideological context of Hobbes's political thought, p. 314.

${ }^{244}$ Cf. Conciliae Magnae Britannicae et Hiberniae, IV, 610-612, citada por SKINNER em The ideological context of Hobbes's political thought, p. 315.

${ }^{245}$ Cf. Thamy POGREBINSCHI, O problema da obediência em Thomas Hobbes, pp. 35 e 36.
} 
comentadores de Hobbes - autores como Strauss, Michael Oakeshott, John Watkins e John Rawls.

Strauss centra sua análise a partir do teor racional da lei de natureza. Para ele, contudo, não é o auto-interesse (como via de regra acontece) o fundamento da passagem para o Estado civil, mas sim o medo da morte. A lei de natureza hobbesiana é na verdade não a base do sistema, mas uma de suas conseqüências, uma vez que o pressuposto geral da teoria de Hobbes, para Strauss, é o direito natural de fazer tudo o que se considere necessário para a preservação ${ }^{246}$. O que conduz a esse direito natural é o elemento central da filosofia de Hobbes - na opinião de Strauss, o medo da morte violenta $^{247}$. Renato Janine Ribeiro procura deixar claro, porém, que o medo não basta há também, em Hobbes, a esperança ${ }^{248}$.

Um dos mais destacados intérpretes é Watkins, que analisa Hobbes sob o ponto de vista da teoria dos jogos. Para ele, haveria em Hobbes um "jogo do estado de natureza", a ser jogado nos seguintes termos:

Fulano e Cicrano são dois homens hobbesianos que vivem em um estado de natureza hobbesiano. Ambos levam consigo armas mortíferas. Uma tarde, enquanto buscam alimento, se encontram numa pequena clareira no meio do bosque. A configuração do bosque torna impossível a fuga. Fulano grita: 'Espera, não nos despedacemos'. Cicrano responde: 'Compartilho teu estado de ânimo. Vamos contar, e quando chegar em dez, cada um de nós jogará sua arma para trás, entre as árvores'. Cada um deles

\footnotetext{
${ }^{246}$ Leo STRAUSS, The political philosophy of Hobbes: its basis and its gênesis, pp. 155, 159 e 160 .

${ }^{247}$ Leo STRAUSS, The political philosophy of Hobbes: its basis and its gênesis, pp. 15 a 17. Cf, também Thamy POGREBINSCHI, O problema da obediência em Thomas Hobbes, pp. 53 e 56.

${ }^{248}$ Thamy POGREBINSCHI, O problema da obediência em Thomas Hobbes, p. 69.
} 
começa então a pensar furiosamente: é ou não é o caso de jogar as armas quando chegarmos em dez? ${ }^{249}$.

Há aqui, quatro possibilidades: Fulano abandona a arma e Cicrano não; Cicrano abandona a arma e Fulano não; ambos abandonam as armas; e nenhum abandona a arma. De acordo com Hobbes, não há como saber qual dessas situações irá ocorrer. Em função disso, o mais prudente a fazer é ambos entregarem as armas "a um terceiro, que a partir desse momento atua como garantidor do respeito aos pactos entre os contratantes desarmados ${ }^{, 250}$. O que faz os homens seguirem a lei de natureza é o autointeresse $^{251}$ - buscando seu próprio bem, a razão recomenda que se abra mão do direito a todas as coisas em troca de segurança.

Outro autor a partilhar dessa visão é David Gauthier. É mais um que analisa o sistema de Hobbes segundo a teoria dos jogos, a partir do dilema dos prisioneiros $^{252}$.

\section{Conclusão}

Com o exposto, não pode ser negado que a concepção de lei de natureza como preceito racional é a primeira e a mais importante formulação do conceito. É a principal caracterização que aparece em todas as obras políticas de Hobbes.

É pela razão, argumenta Hobbes repetidas vezes, que os homens concebem uma possibilidade de sair do penoso estado de guerra e miséria que a pura natureza lhes oferece.

\footnotetext{
${ }^{249}$ J. W. N. WATKINS, Libertá e decisione, Roma, Armando, 1981, p. 86. Citado por BOBBIO, El tercero ausente, pp. 180 e 181.

${ }^{250}$ BOBBIO, El tercero ausente, p. 181.

${ }^{251}$ Cf. Thamy POGREBINSCHI, O problema da obediência em Thomas Hobbes, p. 40.

${ }^{252}$ Richard TUCK, p. 69.
} 
Mas Hobbes, não obstante, deixa claro que a lei de natureza vista apenas como recomendação racional não basta. Ela não é efetivamente uma lei.

Com efeito, elas [as leis de natureza] se apresentam à consciência dos homens como teoremas racionais que dizem respeito à conservação do homem em si e enunciam, para tal fim, regras de prudência ou de técnica [habileté] (...). A bem dizer, mais que ordens que constrangem, ou comandos imperativos, as 'leis naturais' são mais conselhos pragmáticos os quais a razão descobre por meio de abstração prática ${ }^{253}$.

Não dispõe da característica de comando, obrigatório, para que seja lei. Não tem, dessa forma, garantia de eficácia no seu cumprimento.

Tal limitação, contudo, não faz o sistema ruir. A qualidade de ordem é dada à lei de natureza, defende Hobbes, em função não de seu aspecto racional, mas sim em virtude de sua autoria divina, como visto na seqüência.

${ }^{253}$ Simone GOYARD-FABRE, Le droit et la loi dans la philosophie de Thomas Hobbes, pp. 167 e 168. 


\subsection{Lei de natureza como comando de Deus}

Desde o princípio as teorias a respeito da lei de natureza colocavam-na sempre como lei divina. Na Antígona, peça de Sófocles do século V a. C., por exemplo, a oposição fundamental não é propriamente entre as leis humanas e as leis naturais (expressão não empregada no texto), mas sim entre as leis humanas e as leis dos deuses. Por esse motivo Michel Villey - contrariamente à tradição de estudiosos que vê na Antígona uma das primeiras enunciações do direito natural - considera que

na verdade, a famosa tirada de Antígona não concerne precisamente ao direito, mas ao rito religioso funerário. Por outro lado, Antígona não faz de forma alguma apelo, contra o decreto de Creonte, à ordem natural (phisis), mas expressamente à díke [justiça] e a Zeus, às leis religiosas, que, aliás, são aqui leis não escritas (ágraphoi nómoi) que cada um traz em sua consciência. Embora o uso seja esse e nesse sentido exista uma doutrina tradicional da lei de natureza, parece impróprio falar aqui de direito natural ${ }^{254}$.

Em todo caso, é inegável um conflito, na peça, entre o que dispõe a lei dos deuses e a lei dos homens.

De fato, toda a teoria grega a respeito da lei de natureza pode ser considerada um "jusnaturalismo cosmológico de tipo panteísta"255. O logos (ou razão) de Heráclito é elemento divino - e a lei obtida a partir dele é uma lei divina ${ }^{256}$. O próprio Platão, no início de As leis, reafirma o caráter divino da fundação da lei: "O ATENIENSE: A quem atribuis, estrangeiro, a autoria de vossas disposições legais? A

\footnotetext{
${ }^{254}$ Michel VILLEY, A formação do pensamento jurídico moderno, p. 18.

${ }^{255}$ A. Truyol SERRA, História da filosofia do direito e do Estado. Volume I: das origens, à baixa Idade Média, p. 89.

${ }^{256}$ A. Truyol SERRA, História da filosofia do direito e do Estado. Volume I: das origens, à baixa Idade Média, p. 89.
} 
um deus ou a algum homem? CLÍNIAS: A um deus, estrangeiro, com toda a certeza a um deus",257.

Em Cícero, mesmo que ressaltado o caráter racional da lei de natureza, a presença do aspecto divino não pode ser desprezada. $\mathrm{Na}$ definição de lei natural encontrada em Da república, a presença divina é significativa:

$$
\begin{aligned}
& \text { uno será sempre o seu [da lei de natureza] imperador e } \\
& \text { mestre, que é Deus, seu inventor, sancionador e } \\
& \text { publicador, não podendo o homem desconhecê-la sem } \\
& \text { renegar-se a si mesmo, sem despojar-se do seu caráter } \\
& \text { humano e sem atrair sobre si a mais cruel expiação, } \\
& \text { embora tenha conseguido evitar todos os outros } \\
& \text { suplícios }^{258} \text {. }
\end{aligned}
$$

É Deus o elo entre a razão e o homem, bem como o fundamento de toda a natureza da qual será extraída a lei. A origem do direito reside, para o jurista romano, sempre na natureza: ele encontra "a fonte do Direito na natureza"259. A natureza, porém, tem seu princípio e fundamento no elemento divino: “[o]s deuses imortais, por meio de sua força, de sua natureza, de sua razão, de seu poder, de sua mente, de sua virtude ou de qualquer outro termo que expresse com maior clareza o que eu quero dizer, governam toda a Natureza" ${ }^{, 260}$. Além de ter criado e administrar toda a natureza, a ordem divina é também a responsável pela razão, tanto a razão que permeia toda a natureza como a razão não degradada encontrada na alma humana. $\mathrm{O}$

animal cauto, sagaz, complexo, aguçado, dotado de memória, de razão e de prudência, a que chamamos de homem, recebeu do deus supremo uma existência que o

\footnotetext{
${ }^{257}$ PLATÃo, As leis, p. 67.

${ }^{258}$ CÍCERO, Da república, Livro III, § XVII.

${ }^{259}$ CÍCERO, Das leis, Livro I, § 20, p. 41. E também $\S \S 34$ a 36.

${ }^{260}$ CÍCERO, Das leis, Livro I, § 21, p. 41.
} 
coloca em situação ímpar. Pois ele é o único (...) que tem acesso a uma razão e a um pensamento ${ }^{261}$.

Por isso, por ter uma centelha da razão divina, o homem é um ser especial entre os demais e vive em comunidade com os próprios deuses. "Logo, se se observa que não há nada superior à razão e que esta se encontra tanto no homem quanto em Deus, resulta daí que a razão é o vínculo da primeira associação que se estabelece entre o homem e Deus ${ }^{\text {"262 }}$. A lei de natureza, por intermédio da reta razão, atua como elo entre homens e deuses $^{263}$. A origem divina da lei de razão natural é tornada ainda mais clara no livro II de Das leis: "[e] sua origem é tão antiga como a mente divina. Por isso a lei verdadeira e essencial, a que manda e proíbe legitimamente, é a razão justa do grande Júpiter"264. Para Cícero, a lei de natureza é tanto a lei de razão como a lei divina - ambas são a mesma coisa, eis que a razão é caracteristicamente atributo divino compartilhado pelos homens ${ }^{265}$.

O primeiro autor a identificar expressamente as leis de natureza com os mandamentos de Deus foi Philo Judaeus, filósofo alexandrino que viveu na época de Jesus de Nazaré. Comentando as Sagradas Escrituras, Philo Judaeus fez a primeira tentativa conhecida de adequar as teorias dos filósofos clássicos aos ensinamentos provenientes de revelação divina. Com isso, sustentou que o Decálogo de Moisés equivaleria a manifestações específicas das leis gerais da natureza ${ }^{266}$.

Com o advento do cristianismo, o aspecto divino da lei de natureza foi sendo cada vez mais acentuado. Na Idade Média, a

\footnotetext{
${ }^{261}$ CíCERO, Das leis, Livro I, § 22, p. 42.

${ }^{262}$ CÍCERO, Das leis, Livro I, § 23, p. 42.

${ }^{263}$ Cf. CÍCERO, Das leis, Livro I, § 23, p. 42.

${ }^{264}$ CÍCERO, Das leis, Livro II, p. 65.

${ }^{265}$ CÍCERO, Das leis, Livro I, § 22, p. 42.

${ }^{266}$ Robert AUDI (editor), The Cambridge dictionary of Philosophy, p. 666. Philo Judaues é citado por John Milton em Defesa do povo inglês, p. 109.
} 
Natureza era considerada o produto da inteligência e da potência criadora de Deus. E o direito natural torna-se, então, ora a lei inscrita por Deus no coração do homem (...), ora a lei revelada pelos textos sagrados (...), ora, ainda, a lei comunicada aos homens por Deus, por meio da razão ${ }^{267}$.

A partir do cristianismo, "a lei natural passa a ser - direta ou indiretamente - a lei de Deus. Assim como Deus estabeleceu as leis que regulam o movimento dos corpos, determinou as leis que regulam a conduta do homem,"268. Ao homem cabe, a partir de agora, decifrar a lei de Deus. Pode desvendá-la de duas formas: diretamente, por intermédio da revelação (registrada nas Sagradas Escrituras); ou indiretamente, pelo uso da capacidade racional.

Conforme Tomás de Aquino, a lei de natureza é obtida a partir da lei eterna, definida como "razão divina que governa o mundo" ${ }^{269}$. É a razão humana o elo que faz a lei de natureza participar da lei eterna; em outras palavras, o homem, ser dotado de razão, tem capacidade de sondar a lei eterna, verdadeira linguagem cósmica, e a partir disso determinar o conteúdo da lei de natureza. Ao proceder dessa maneira, o homem encontra o sentido da lei natural: "[a] lei natural consta de um preceito único e genérico do qual a razão deduz todos os outros. Esse preceito muito genérico consiste na máxima bonum faciendum, male vitandum, que prega fazer o bem e evitar o mal"270.

Em Grócio, a função de Deus no fundamento da lei de natureza foi sendo alterada no decorrer de suas obras. No início, Deus era visto, de acordo com a tradição, como o autor das leis de natureza. Eram leis porque dependiam da vontade de Deus:

\footnotetext{
${ }^{267}$ Norberto BOBBIO, Locke e o direito natural, p. 31.

${ }^{268}$ Norberto BOBBIO, Locke e o direito natural, p. 37.

${ }^{269}$ Norberto BOBBIO, Locke e o direito natural, p. 38.

${ }^{270}$ Norberto BOBBIO, Locke e o direito natural, p. 37, citando SANTO TOMÁS DE AQUINO, Suma teológica, q. 94, art. 2.
} 
"[o] que Deus mostrou ser Sua vontade é a lei" Direito da guerra e da paz Grócio faz a célebre afirmação de que as leis iriam obrigar a humanidade mesmo que não existisse Deus ou que Deus não se preocupasse com os afazeres humanos. As leis de natureza só poderiam ser atribuídas a Deus no sentido de que por seu deleite seus princípios encontram-se em nós ${ }^{272}$. Grócio defende que todo animal busca sua preservação, e faz de tudo para mantê-la ${ }^{273}$. E se esse instinto é governado por reflexão racional para o bem da sociedade, é a reta razão, e não mais Deus, que proíbe o que é repugnante à sociedade ${ }^{274}$.

\section{Lei de natureza como comando de Deus em Hobbes}

Além de definir lei de natureza como preceito da razão, Hobbes afirma que a lei de natureza é também um comando ou ordem de Deus. "Tudo o que parecia proceder apenas do homem, parece agora encontrar seu fundamento e sua fonte em Deus ${ }^{\text {275 }}$. Ela não é tratada mais como mera recomendação, preceito ou ditame, mas como lei em sentido forte, como ordem, mandamento ou comando. Com isso, pode-se concluir que "Hobbes trabalha com duas definições de lei natural (ou lei da natureza) em sua filosofia política e moral"276. O que diferencia as duas noções é a aplicação do conceito de lei em cada uma delas ${ }^{277}$ : lei em sentido estrito é mandamento, é ordem; neste caso, lei natural só é lei se for tomada enquanto mandamento divino.

\footnotetext{
${ }^{271}$ Richard TUCK, The 'modern' theory of natural law, p. 112, citando Hugo Grócio, De iure praedae comentarius, I, p. 8.

${ }^{272}$ Richard TUCK, The 'modern' theory of natural law, p. 112, citando Hugo Grócio, Direito da guerra e da paz, , p. XIX.

${ }^{273}$ Richard TUCK, The 'modern' theory of natural law, p. 112, citando Hugo Grócio, Direito da guerra e da paz, , p. 24.

${ }^{274}$ Cf. Richard TUCK, The 'modern' theory of natural law, p. 112.

${ }^{275}$ ZARKA, Loi naturale et loi civil chez Thomas Hobbes, p. 68.

${ }^{276}$ Cícero ARAÚJO, As duas definições de lei natural em Hobbes, p. 189.

${ }^{277}$ Cícero ARAÚJO, As duas definições de lei natural em Hobbes, p. 190.
} 
Trata-se da segunda formulação, tanto em termos de localização na argumentação como em termos de importância para o sistema. A importância dessa concepção reside sobretudo na força vinculante que o comando divino possui para o crente, face ao caráter meramente de recomendação do preceito racional. O que é bastante relevante para o sistema geral de suas idéias - essa obrigatoriedade é necessária para que os homens, que não são apenas seres de razão mas também de paixão, saiam do estado de natureza em direção ao Estado civil.

Nos três livros principais sobre política, a noção de comando divino é trabalhada em momentos semelhantes. Após o tratamento dado à lei natural como ditame da razão, com sua definição e a enumeração das leis naturais em espécie, Hobbes faz algumas considerações gerais sobre o tema. Nessas considerações expõe a idéia de que a lei de natureza, tomada simplesmente como ditame racional, não é exatamente uma lei, dada a sua ausência de imperatividade. Mas, acrescenta o filósofo, a lei de natureza não é apenas preceito da razão - ela é também uma ordem de Deus. E, nesse sentido, é lei em sua plenitude. Posteriormente, Hobbes confirma a idéia demonstrando como todos os conteúdos das leis de natureza encontram-se presentes nas Sagradas Escrituras.

Nos Elementos, até certo ponto Hobbes trata a lei de natureza apenas como ditame da razão ${ }^{278}$. Mas isso gera um problema: se a lei de natureza é razão, então ela não é propriamente uma lei, já que lei é comando e razão não é comando. Nas considerações feitas após a enumeração das leis de natureza em espécie, Hobbes busca resolver o impasse ao inserir a noção de lei divina. A lei natural é comando, e portanto lei, justamente porque é divina:

\footnotetext{
${ }^{278}$ Até o $§ 11$ do capítulo XVII.
} 
E visto que a lei, falando propriamente, é um comando, e estes ditames, por procederem da natureza, não são comandos, só podem portanto ser chamados de leis não no que respeita à natureza, mas no que respeita ao autor da natureza, Deus Todo-Poderoso ${ }^{279}$.

A necessidade de se colocar a lei de natureza como um comando propriamente dito, além da importância a ser adquirida na construção do Estado civil, também atua para resolver um problema colocado pouco antes por Hobbes ${ }^{280}$. O filósofo havia concluído que a lei de natureza não teria validade absoluta, mas poderia ser alterada pelo consentimento dos homens. A partir disso o filósofo acaba tendo que admitir que a lei de natureza não é um comando, já que quem é submetido a ela pode escolher alterá-la (o que seria impossível para um comando, alterável apenas por quem o coloca). Se a lei de natureza não é um comando, então não é lei. Inserida a autoria divina, ela passa a ser comando emanado por Deus e, conseqüentemente, lei cuja obediência é obrigatória.

As conseqüências de uma "dupla definição da lei natural"281 são relevantes. Com a inser玢o de Deus, a lei de natureza deixa de ter um s sentido e passa a ter dois. Ela n 鋓 apenas preceito racional, mas tamb閙 comando de Deus. Ela possui duas defini珲es:

Hobbes apresenta a lei natural, por um lado, como uma s䦕ie de 'mandamentos divinos', e o direito natural como a 'liberdade' que deixa a cada um de defender sua 'vida e membros'. Numa outra defini玢o, por閙, a lei natural aparece simplesmente como 'conclus鮡s ou teoremas da

\footnotetext{
${ }^{279}$ Elementos, XVII, $\S 12$, p. 118.

${ }^{280}$ Elementos, XVII, § 12, p. 118.

${ }^{281}$ Cícero ARAÚJO, As duas definições de lei natural em Hobbes, p. 189.
} 
raz銒', aos quais corresponde a pr醫ica das 'virtudes morais $^{282}$.

A princ毫io, Hobbes esfor鏰-se por conciliar ambas, apontando que elas $\mathrm{n}$ 鋓 $\mathrm{s}$ 鋓 excludentes. $\mathrm{N}$ 鋓 $\mathrm{s}$ 鋓 a mesma coisa (posto que uma das defini珲es imperativa e a outra n鋓 ), mas uma defini玢o n銒 atinge, em nenhum momento nos textos de Hobbes, a al鏰da da outra: na esfera onde uma n鋓 alcan鏰 a regula玢o de determinada situa玢o (na quest䥕 da obrigatoriedade), a outra ocupa seu espa鏾.

Um dado importante é que o que garante a qualidade de comando para a lei de natureza não é sua natureza intrínseca, mas sua autoria. Ela não é um comando porque possui característica de comando, mas porque vem de Deus. "Existem as leis que procedem da autoridade suprema do Criador, isto é, da vontade de Deus: são as leis de natureza"283. Essa questão da autoria mostra-se determinante. É possível defender que o que diferencia as diversas espécies de lei é quem as promulga: a lei editada por Deus é a lei natural; a lei editada pela persona civitatis é a lei civil ${ }^{284}$. “A diferença entre a lei natural e a lei civil procede, nesse sentido, da diferença entre a vontade do Deus eterno e a vontade do deus mortal"285. A autoria não apenas distingue os diferentes tipos de lei, mas também suas qualidades. A imutabilidade e a universalidade da lei de natureza decorrem do poder irresistível e eterno de Deus ${ }^{286}$. Ou seja: Hobbes não parte do que a coisa é, mas sim de onde a coisa vem. É a origem, a autoria, que vai determinar as características de cada tipo de lei. A lei divina é eterna porque vem de Deus - a causa de sua eternidade é sua autoria. Do mesmo modo, a lei civil é mutável porque dada pelo homem.

\footnotetext{
${ }^{282}$ Cícero ARAÚJO, As duas definições de lei natural em Hobbes, p. 189.

${ }^{283}$ Simone GOYARD-FABRE, Le droit et la loi dans la philosophie de Thomas Hobbes, p. 167.

${ }^{284}$ ZARKA, Loi naturelle et loi civile, p. 57.

${ }^{285}$ ZARKA, Loi naturelle et loi civile, p. 60.

${ }^{286}$ ZARKA, Loi naturelle et loi civile, p. 60.
} 
Ao identificar a lei de natureza com o mandamento de Deus, Hobbes não se afasta da tradição e nem do pensamento de seus contemporâneos. Entre eles, o elemento divino sempre esteve muito presente na lei de natureza. Em Filmer, o caráter de comando de Deus domina completamente a natureza da lei natural, praticamente não havendo espaço para a razão na delimitação do conceito. Com efeito, Filmer procura derivar toda sua teoria a partir da vontade divina como revelada nos textos sagrados - e com a lei de natureza não poderia ser diferente. Lei natural, para ele, é a vontade de Deus. Essa vontade de Deus nem mesmo é acessível - via razão, como para os jusnaturalistas clássicos - pela mente humana. Ela somente pode ser desvendada quando revelada pela vontade divina aos homens ${ }^{287}$. Já no pensamento de Locke, como visto, a vontade de Deus foi cedendo espaço à razão na medida em que as obras foram se sucedendo. Nos Ensaios sobre a lei de natureza, "sua [de Locke] posição fundamental era voluntarista: a lei de natureza foi criada pela vontade contingente de Deus, e a ética diria respeito a ter um conhecimento adequado da lei divina"288. Realmente, Locke define lei de natureza precisamente enquanto manifestação do desígnio divino: "[d]aí que essa lei de natureza possa ser descrita como decreto da vontade divina discernível pela luz da natureza"289, ocupando a razão um lugar apenas acessório, o de descobrir em que consistem as ordens divinas. Além disso, Deus aparece também como fonte de obrigação das leis de natureza: "[a] fonte de onde nascem as obrigações da lei natural é a primeira: a lei natural é obrigatória na medida em que deriva diretamente do poder divino, isto é, do poder que Deus tem sobre os homens pelo

\footnotetext{
287 “A lei natural em Filmer não é uma norma acessível às faculdades naturais do homem. Logo, não é possível que os homens a consultem para entenderem seus direitos e deveres. Filmer sustenta que a única regra pela qual os homens devem pautar a sua conduta é a vontade revelada de Deus. A revelação, por sua vez, comanda a submissão absoluta aos pais e aos poderes instituídos". Maria Cecília Pedreira de ALMEIDA, Escravos, súditos e homens: a noção de consentimento na polêmica Locke-Filmer, p 123.

${ }^{288}$ Marck GOLDIE, Introdução aos Ensaios políticos, p. XXII.

${ }^{289}$ John LOCKE, Ensaios políticos, p. 102.
} 
poder da criação"290. Já no Segundo tratado, se a razão ocupa um local mais proeminente na argumentação, nem por isso a idéia de criação divina deixa de ser utilizada por Locke. Pode-se defender, inclusive, que "no sistema por ele [Locke] exposto nos Dois tratados, a lei natural era ao mesmo tempo um mandamento divino, uma norma da razão e uma lei presente na natureza mesma das coisas"291. A lei de Deus já é equiparada à lei de natureza $\operatorname{logo}$ no início do texto ${ }^{292}$, deixando Locke posteriormente claro que a infração à lei de natureza corresponde a infringir as medidas dadas por Deus aos homens ${ }^{293}$. E Milton, por fim, argumenta, na Defesa do povo inglês, que a lei de natureza guarda correspondência com a lei divina: "[s]ou e sempre fui da opinião, Salmásio, de que a lei de Deus concorda exatamente com a lei de natureza"294. Mas essa relação não é de identidade plena, haja vista que para o republicano inglês a lei natural é mais abrangente que a lei divina e compreende os preceitos desta última ${ }^{295}$.

Hobbes, na seqüência do texto dos Elementos, trata da confirmação do que afirmou a partir da Bíblia ${ }^{296}$. Retoma as afirmações do capítulo precedente logo ao começo:

As leis mencionadas nos capítulos anteriores são chamadas leis de natureza, por serem ditadas da razão natural, e também leis morais, porque dizem respeito às maneiras e à convivência dos homens uns com os outros. Da mesma forma, elas são também leis divinas, em consideração ao autor daquelas, Deus Todo-Poderoso; e

\footnotetext{
${ }^{290}$ Norberto BOBBIO, Locke e o direito natural, p. 126.

${ }^{291}$ Peter LASLETT, Introdução aos Dois tratados sobre o governo, p. 119.

${ }^{292}$ Cf. John LOCKE, Dois tratados sobre o governo, p. 379.

${ }^{293}$ Cf. John LOCKE, Dois tratados sobre o governo, p. 386.

${ }^{294}$ John MILTON, Escritos políticos, p. 198. O texto Defesa do povo inglês, de Milton, foi publicado em 1651 (mesmo ano da publicação do Leviatã) como refutação da obra Defenso Regia, publicada anonimamente por Salmásio em 1649.

${ }^{295}$ Cf. Martin DZELZAINIS, Introdução aos Escritos políticos, p. XXVIII.

${ }^{296}$ Elementos, XVIII.
} 
devem portanto concordar ou, pelo menos, não repugnar a palavra de Deus revelada na Santa Escritura ${ }^{297}$.

Novamente faz-se presente a noção de que é a autoria da lei natural por Deus que a torna lei em sentido próprio. Nesse sentido, Hobbes fica de acordo "com a tradição de São Paulo e dos Padres da Igreja, para quem o conteúdo das leis de natureza concorda rigorosamente com as regras evangélicas" ${ }^{298}$.

Durante o restante do livro Hobbes ainda aproxima algumas vezes a lei natural da lei divina ${ }^{299}$. Um fator que une ambas é que a lei divina também diz respeito à consciência:

Pois visto que as leis do reino dos céus - como foi mostrado na parte I, capítulo V, seção 10 - são ditadas para a consciência apenas, que não está sujeita à compulsão ou à coação, não seria congruente ao estilo do Rei dos Céus coagir os homens a submeterem suas ações a ele, mas antes apenas orientá-los; nem para aquele que professa que a essência da sua lei é o amor, para obter algum dever de nós por meio do medo de um castigo eterno $^{300}$.

Vê-se, assim, que Hobbes, diferentemente de positivistas jurídicos dos séculos XIX e XX como John Austin e Hans Kelsen ${ }^{301}$, não coloca a sanção como aspecto determinante na caracterização da lei. "Hobbes não defende que a existência de sanção seja parte do significado da lei”,302. A lei não é lei porque é coativa ou por possuir sanção, mas é lei porque emanada da autoridade competente para legislar (e, no caso

\footnotetext{
${ }^{297}$ Elementos, XVIII, § 1, p. 121.

${ }^{298}$ Simone GOYARD-FABRE, Le droit et la loi dans la philosophie de Thomas Hobbes, p. 47.

${ }^{299}$ Exemplos: Parte II, capítulo II, § 3, p. 146. Outro: Livro II, capítulo VI, § 10, pp. 183 e 184. Usa, por exemplo, as duas como sinônimas na parte II, capítulo IX, § 1, p. 206. E na parte II, capítulo X, § 5, pp. 213 e 214, lida bastante com ambas como se fossem exatamente a mesma coisa.

${ }^{300}$ Elementos, parte II, capítulo VII, § 9, p. 192.

${ }^{301}$ Cf. M. M. GOLDSMITH, Hobbes on law, p. 276.

${ }^{302}$ M. M. GOLDSMITH, Hobbes on law, p. 276.
} 
específico da lei de natureza, a autoridade legisladora é ninguém menos que o próprio Deus).

O filósofo ainda trata a lei divina como lei natural ao defender que o soberano, que não está sujeito a nenhuma lei civil, está sujeito à lei de Deus ${ }^{303}$.

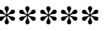

Em Do cidadão a lei divina é novamente a segunda forma que a lei natural assume (a lei moral aparece antes no texto ${ }^{304}$, mas sem nenhum desdobramento), sendo também a segunda mais comum e mais relevante. Mas ela não possui apenas uma diferença de local e de quantidade em relação ao preceito da razão: aqui há outra vez uma diferença qualitativa, pois o comando divino é uma ordem, um comando, desfruta de poder vinculante, ao passo que o preceito da razão é mera recomendação.

Antes de começar propriamente o livro, na Epístola Dedicatória as leis naturais são colocadas como ditados divinos: "[a]queles acréscimos que tratam do reino de Deus foram incorporados com a intenção de que os ditados de Deus Todo-Poderoso, na lei de natureza, não pareçam repugnar à lei escrita, a nós revelada em sua palavra"305. Porém a formulação não recebe desenvolvimentos.

A lei natural como lei divina é utilizada na argumentação pela primeira vez nas considerações gerais sobre as leis naturais ${ }^{306}$, naquela afirmação de que a lei natural enquanto ditame racional não seria lei, porque é apenas um ditado da razão. Mas, por outro lado, a lei natural é lei se vista como lei divina. É a mesma concepção expressa nos Elementos.

\footnotetext{
${ }^{303}$ P. ex., na parte II, capítulo VIII, § 6, p. 199. Aparece o soberano submetido às duas na parte II, capítulo IX, § 1, p. 206.

${ }^{304}$ Do cidadão, III, § 31, p.72.

${ }^{305}$ Do cidadão, p. 8.

${ }^{306}$ Do cidadão, no final do capítulo III.
} 
Contudo, o que denominamos lei de natureza, como nada mais são que certas conclusões entendidas pela razão, acerca das coisas que devem ser feitas ou omitidas - ao passo que uma lei, para falar de maneira própria e acurada, é o discurso de quem tem o direito de mandar que façam ou deixem de fazer determinadas coisas -, a bem dizer elas não são leis, dado que procedem da natureza ${ }^{307}$.

É a partir disso que as leis naturais precisam ser consideradas divinas:

Porém, na medida em que [as leis de natureza] são outorgadas por Deus nas Sagradas Escrituras - como veremos no capítulo seguinte - é muito apropriado chamálas pelo nome de leis: pois a Sagrada Escritura é o verbo de Deus mandando, pelo maior de todos os direitos, sobre todas as coisas $^{308}$.

Ou seja: a lei natural é lei apenas se lei divina. Aqui Hobbes coloca também as Sagradas Escrituras como concretização das ordens divinas - as leis naturais são leis quando positivadas, quando colocadas numa tábua de lei, mesmo que elaboradas por Deus. Elas saem do plano da mera consciência humana (como razão) e adquirem vida própria, deixando de apenas recomendar e passando, por conseguinte, a mandar.

Tem-se, então, o segundo caráter da lei de natureza, da mesma forma que nos Elementos. Ela existe enquanto lei divina, juntamente com a lei da razão. Renato Janine Ribeiro, em nota, considera que Hobbes dá "uma definição ambígua para o termo lei. As leis não são leis porque são teoremas, mas são leis porque Deus assim o quer"309. É novamente a autoria divina que dá à lei de natureza seu caráter de lei.

\footnotetext{
${ }^{307}$ Do cidadão, p. 74.

${ }^{308}$ Do cidadão, p. 74.

${ }^{309}$ Do cidadão, p. 365 . O itálico é do autor.
} 
Logo em seguida, demonstrando o quanto a concepção tem importância, há um capítulo inteiro, "Que a lei de natureza é lei divina"310, no qual desde o início Hobbes afirma que a lei natural e moral é lei divina:

A mesma lei que é natural e moral é merecidamente chamada divina: tanto porque a razão, que é a lei de natureza, foi outorgada por Deus a cada homem como regra de suas ações, quanto porque os preceitos de vida que dela derivamos coincidem com aqueles que foram promulgados pela Majestade Divina como leis de seu reino terreno, por intermédio de Nosso Senhor Jesus Cristo e de seus santos profetas e apóstolos ${ }^{311}$.

Não há mudança em relação ao disposto anteriormente: é lei divina porque foi dada por Deus aos homens como regra de suas ações. E os preceitos que o homem tira da razão para se conservar são os mesmos que Deus lhes deu. Há, assim, identidade entre a formulação da lei de natureza como regra racional e a lei de natureza como comando divino. Com isso, o que Hobbes havia concluído por meio da razão demonstra agora como estando presente também nas Sagradas Escrituras ${ }^{312}$. É, portanto, no texto bíblico que se corporifica a lei de Deus. "A identificação da lei natural com a lei divina se opera pela mediação da Sagrada Escritura"313.

A Sagrada Escritura também opera no sentido de unir os dois pontos de vista acerca da lei natural. "Se a lei de natureza se situa bem na flexão entre a palavra do homem e a palavra de Deus, toda a questão é doravante saber qual o status da palavra de Deus e a relação que se estabelece entre o preceito da razão e o comando divino"314.

\footnotetext{
${ }^{310}$ O capítulo IV.

${ }^{311}$ Do cidadão, IV, § 1.

${ }^{312}$ Do cidadão, p. 75.

${ }^{313}$ ZARKA, Loi naturelle et loi civile, p. 67.

${ }^{314}$ ZARKA, Loi naturelle et loi civile, p. 67.
} 
Ela, a Sagrada Escritura, é quem confere racionalidade às ordens de Deus, ligando assim o disposto pela razão divina à razão humana.

O caráter racional da lei divina é exposto novamente no final do livro, no momento em que Hobbes apresenta a classificação dos tipos de leis ${ }^{315}$. A lei divina divide-se em lei divina natural e lei divina $\operatorname{positiva~}^{316}$. É apontada, na seqüência, uma nova definição de lei natural, a lei divina natural, dela fazendo parte atuando tanto Deus como a razão: "[n]atural é aquela [lei] que Deus declarou a todos os homens através de sua palavra eterna, com eles nascida - ou seja, através da razão natural”317.

E, além disso, a Sagrada Escritura atesta a autoria da lei de Deus:

A passagem do ponto de vista ético para o ponto de vista teológico opera-se pela consideração do autor das leis naturais. A lei natural torna-se lei divina por confirmação da Escritura. A Sagrada Escritura nos informa ainda que Deus inscreveu sua lei no coração dos homens (...). A Escritura atesta também que a busca por paz e o princípio de reciprocidade vêm das prescrições divinas ${ }^{318}$.

A seguir, o filósofo aponta que a lei divina "repousa" na reta razão ${ }^{319}$. Se a lei natural é a reta razão, e a lei divina é lei natural, então a lei divina é reta razão. No decorrer do capítulo, apresenta inúmeras citações bíblicas para corroborar o que havia defendido anteriormente. Por exemplo, uma passagem - "Dai bebida forte aos que perecem, e o vinho aos amargosos de espírito: Para que bebam, e se esqueçam da sua pobreza, e do seu trabalho não se lembrem mais" ${ }^{, 320}$ - é chamada estranhamente para

\footnotetext{
${ }^{315}$ Em Do cidadão é o capítulo XIV, que trata especificamente de leis e crimes.

${ }^{316}$ Do cidadão, XIV, § 4, pp. 218 e 219.

${ }^{317}$ Do cidadão, XIV, § 4, p. 219.

${ }^{318}$ ZARKA, Loi naturelle et loi civile, p. 68.

${ }^{319}$ Do cidadão, IV, $§ 2$, pp. 75 e 76.

${ }^{320}$ Retirada de Provérbios 31, 6.
} 
atestar que a lei de natureza que proíbe embriaguez encontra respaldo bíblico ${ }^{321}$. No final há uma passagem a defender que a lei de natureza é inteira divina e é a lei de Cristo $^{322}$. Sendo inteira divina, considera-se que ela não atua apenas na falta da recomendação racional, ou que ambas as formulações dividem espaço, mas que as qualidades divinas e racionais são igualmente constituintes da lei de natureza.

Após o término do núcleo central sobre lei de natureza ${ }^{323}$, o filósofo passa a tratar da formação do Estado civil, da soberania e de outros temas. A partir daí, a concepção de lei natural como lei divina é utilizada somente esporadicamente. Por exemplo, ao cuidar dos deveres do soberano, Hobbes assevera que a razão reta é a lei natural, a lei moral e a lei divina ${ }^{324}$.

A terceira e última parte do livro é dedicada à religião. É uma decorrência direta do que foi defendido anteriormente acerca das leis de natureza e das leis divinas:

Nos capítulos anteriores, provamos - com base tanto na razão como na escritura sagrada - que o estado de natureza, ou de liberdade absoluta (condição em que vivem aqueles que nem governam nem são governados), é um estado de anarquia, ou de guerra: que as leis de natureza são os preceitos que nos capacitam a evitar tal estado; que não pode haver governo civil sem um soberano; e que qualquer um que tenha obtido esse poder soberano deve ser simplesmente obedecido, isto é, deve ter nossa obediência em todas as coisas que não repugnem aos mandamentos de Deus ${ }^{325}$.

\footnotetext{
${ }^{321}$ Do cidadão, IV, § 19, pp. 84 e 85.

${ }^{322}$ Do cidadão, IV, § 24, p. 87.

${ }^{323}$ Formada pelos capítulos II, III e IV.

${ }^{324}$ Do cidadão, XIII, § 2, p. 198.

${ }^{325}$ Do cidadão, p. 239.
} 
Para saber o que repugna ou não aos mandamentos de Deus, Hobbes investiga, no final do livro, quais são as leis divinas. Nessa investigação, Hobbes deixa claro que as leis naturais são as leis divinas e que ambas são racionais:

Como a palavra de Deus, em seu reino natural, é tãosomente a razão reta (assim, pelo menos, se supõe), e como por outro lado as leis dos reis apenas podem ser conhecidas pelas palavras deles, evidencia-se então que as leis de Deus, quando ele reina tão-só naturalmente, nada mais são que as leis naturais, ou seja, aquelas que expusemos nos capítulos II e III, e que deduzimos dos ditames da razão - a humildade, a eqüidade, a justiça, a misericórdia, e outras virtudes morais favoráveis à paz, que mandam os homens cumprirem seus deveres uns para com os outros -, e ainda aquelas que a razão reta acrescentar, a propósito da honra e culto devidos à Majestade Divina. Não precisamos repetir quais são essas leis naturais ou virtudes morais; mas devemos investigar o que a mesma razão natural dita no tocante às honras e ao culto divino, isto é, que leis sacras ela determina ${ }^{326}$.

Além disso, o aspecto racional da lei divina também é ressaltado algumas outras vezes $^{327}$

A lei natural enquanto lei divina, no Leviatã, é postulada logo quando Hobbes formula a primeira lei de natureza. O homem, para obter a paz, deve abrir mão do seu direito a todas as coisas - mas não sozinho, e sim quando todos os outros concordarem em fazer o mesmo. Sobre isso o filósofo afirma que “[é] esta a lei do

\footnotetext{
${ }^{326}$ Do cidadão, XV, § 8, p. 245.

${ }^{327}$ Do cidadão, XV, § 15, p. 254, e XV, § 17, p. 256.
} 
Evangelho: Faz aos outros o que queres que te façam a ti",328. Mas, assim como nos demais livros, após essa breve menção não há por enquanto um desenvolvimento de suas implicações.

Novamente como nas outras obras, a lei natural como comando divino é fundamentada nas considerações gerais acerca das leis de natureza, justamente para conferir-lhes imperatividade:

A estes ditames da razão os homens costumam dar o nome de leis, mas impropriamente. Pois eles são apenas conclusões ou teoremas relativos ao que contribui para a conservação e defesa de cada um, enquanto a lei, em sentido próprio, é a palavra daqueles que têm o direito de mando sobre os outros. No entanto, se considerarmos os mesmos teoremas como transmitidos pela palavra de Deus, que tem direito de mando sobre todas as coisas, nesse caso serão propriamente chamados leis ${ }^{329}$.

Como as leis naturais enquanto preceitos da razão não se sustentam sozinhas, porque ineficazes, Hobbes precisa adicionar a lei divina à equação. Nesse ponto, novamente a lei de natureza adquire um duplo caráter, como preceito da razão e como ordem de Deus, obtendo da segunda formulação sua força vinculante.

Como nos Elementos e em Do cidadão, a abordagem principal do tema se encerra e volta a aparecer apenas em momentos esparsos do texto.

Assim, ao tratar da liberdade dos súditos ${ }^{330}$, Hobbes apresenta a lei natural como lei divina ao determinar que o soberano continua atado a ela mesmo após a instituição do governo: "cada súdito é autor de todos os atos praticados pelo soberano,

\footnotetext{
${ }^{328}$ Leviatã, XIV, § 5, p. 113.

${ }^{329}$ Leviatã, XV, § 41, p. 137.

${ }^{330}$ Leviatã, XXI.
} 
de modo que a este nunca falta o direito seja ao que for, a não ser na medida em que ele próprio é súdito de Deus, e conseqüentemente obrigado a respeitar as leis de natureza" ${ }^{331}$. O soberano, dessa feita, nunca deixa de vincular-se à lei de natureza. Por não estar sujeito a nenhuma lei civil, a única lei que deve seguir é a lei de natureza - não porque a lei de natureza é racional, mas porque é divinal.

Ao discorrer a respeito das leis civis, também no Leviatã Hobbes oferece uma divisão dos gêneros de leis ${ }^{332}$. Em relação às leis divinas o filósofo defende que as leis naturais são leis divinas por serem eternas e imutáveis:

As leis positivas divinas (pois sendo as leis naturais eternas e universais são todas elas divinas) são as que, sendo os mandamentos de Deus (não desde toda eternidade, nem universalmente dirigidas a todos os homens, mas apenas a um determinado povo, ou a determinadas pessoas), são declaradas como tais por aqueles a quem Deus autorizou assim os declarar ${ }^{333}$.

O interessante aqui a notar é que a lei natural configura-se como lei divina não apenas por ter como autor Deus, mas também por características que lhe são próprias: a eternidade e a imutabilidade. É uma abordagem nova e diferente em relação ao que havia sido discutido antes (tanto nos demais livros como nas outras passagens do Leviatã), quando era tão somente a autoria que caracterizava a lei natural como lei divina. Essa identificação da lei divina com a lei natural permite que Hobbes divida o gênero das leis em duas espécies básicas: "Hobbes também objetivava eliminar outras idéias que ele acreditava serem supérfluas. Na sua discussão sobre a divisão costumeira

\footnotetext{
${ }^{331}$ Leviatã, XXI, p. 182.

${ }^{332}$ Leviatã, XXVI.

${ }^{333}$ Leviatã, XXVI, § 40, p. 243.
} 
da lei em divina, natural e civil ele foi capaz de eliminar a lei divina porque ele sustentava que ela era idêntica à lei natural”,334.

E em diversas outras passagens Hobbes ainda deixa claro que lei de natureza e lei divina são uma e mesma coisa ${ }^{335}$.

No Diálogo, a lei de natureza vista como ordem de Deus é novamente secundária em relação aos ditames da razão, mas nem por isso é totalmente desconsiderada.

Há uma aproximação no começo do texto, isolada e sem grandes implicações, entre lei divina e razão: “[c]ontudo a eqüidade e a razão, leis divinas e eternas que constrangem todos os homens de todas as épocas em todos os lugares, ainda sobreviveriam, embora obedecidas por poucos"336. São a eqüidade e a razão leis divinas e eternas. Todos esses conceitos enquadram-se no que Hobbes defende nas outras obras a respeito da lei de natureza. Lei de natureza é tanto eqüidade como razão, lei divina e lei eterna.

Tratando da obediência à lei da razão pelo soberano, Hobbes justifica sua posição apelando à lei divina:
É também um ditame da lei da razão que as leis estatutárias são um meio necessário da segurança e do bem-estar do homem no mundo presente, e devem ser obedecidas por todos os súditos, como deve ser obedecida

\footnotetext{
${ }^{334}$ CAIRNS, Huntington. Hobbes' theory of law, p. 66.

${ }^{335}$ Quais sejam: Leviatã, XXVI, § 41, p. 243; XXVI, § 41, p. 245; XXVI, § 41, p. 245; XXIX, p. 275; XXX, p. 283; XXX, p. 299; XXX, p. 303; XXXIII, p. 328; XLII, p. 420; XLII, p. 434; XLII, p. 486; XLIII, p. 492; Capítulo XLIII, p. 502.

${ }^{336}$ HOBBES, Um diálogo entre um filósofo e um jurista, p. 36.
} 
pelo rei e pelos súditos a lei da razão, porque é a lei de Deus $^{337}$.

O rei deve obedecer à lei da razão porque ela é uma ordem de Deus.

A mesma necessidade do soberano submeter-se às regras de Deus é objeto de debate posteriormente, na discussão sobre a soberania do mando do rei. É mais um dos raros pontos em que o filósofo e o jurista concordam. Afirma o filósofo que "o rei precisa se submeter às leis de Deus, tanto as escritas como as não escritas, e a nenhuma outra",338. Ao que o jurista completa: "[q]uanto à lei da razão, que é a eqüidade, é bastante certo que há apenas um único legislador: Deus"339. Para ser complementado pelo filósofo: "[d]isso se segue que aquilo a que o senhor chama Direito comum, diferente da lei estatutária, não é nada mais que a lei de Deus"340.

\section{Interpretações da lei de natureza como comando de Deus}

Foi somente nas primeiras décadas do século XX que a concepção de lei de natureza enquanto ordem de Deus passou a ser debatida pelos intérpretes do pensamento de Hobbes. Após os primeiros estudos, a questão foi objeto de inúmeras querelas, que até o presente momento ainda não cessaram. A discussão é conhecida como a "polêmica Taylor-Warrender", em função do nome dos seus principais defensores. A conseqüência que vem sendo mais debatida diz respeito à mudança de obrigatoriedade decorrente da origem divina da lei natural.

$\mathrm{O}$ primeiro texto a lidar com o assunto foi The ethical doctrine of Hobbes, de A. E. Taylor, publicado em 1938. É, talvez, o texto mais influente sobre

\footnotetext{
${ }^{337}$ HOBBES, Um diálogo entre um filósofo e um jurista, p. 42.

${ }^{338}$ HOBBES, Um diálogo entre um filósofo e um jurista, p. 53.

${ }^{339}$ HOBBES, Um diálogo entre um filósofo e um jurista, p. 53.

${ }^{340}$ HOBBES, Um diálogo entre um filósofo e um jurista, p. 53.
} 
Hobbes: é possível que se dividam os estudos hobbesianos entre os que seguem a visão clássica e os que seguem Taylor ${ }^{341}$. Taylor afirma que a visão tradicional sobre Hobbes tem origem numa leitura tendenciosa do Leviatã. Ele defende três pontos para provar que as leis de natureza podem ser consideradas leis propriamente ditas, ou seja, obrigatórias mesmo sem a existência de um soberano civil. O primeiro ponto é em função da característica de ditame (ou ditado) da lei de natureza. Para Taylor, ditados não são conselhos ou recomendações, pois possuem caráter imperativo. São, mais que isso, teoremas que proíbem certas ações - a linguagem de Hobbes é imperativa ou quase sempre imperativa: “[o] caráter imperativo da lei natural é portanto inseparável dela” ${ }^{342}$. O segundo ponto decorre do caráter deontológico do pensamento de Hobbes, a partir dos deveres a que o soberano está submetido em função das leis de natureza ${ }^{343}$. É no terceiro ponto que a questão da procedência divina da lei de natureza é determinante. Aqui ela se mostra, sem margem de dúvidas, como um comando propriamente dito:

[s]e o preenchimento da lei de natureza é um dever do soberano [em função do segundo ponto], segue-se que a lei de natureza é um comando, e um comando a razão para a obediência na qual ela é o preceito de uma 'pessoa' com o direito de comandar ${ }^{344}$.

Essa pessoa que detém o direito de comandar é Deus:

[e]u só posso ver as afirmações de Hobbes consistentes uma com a outra pela suposição de que ele quis dizer muito seriamente o que ele freqüentemente diz, de que a

\footnotetext{
${ }^{341}$ B. H. Baumrin, Hobbes Leviathan: Interpretation and criticism, p. 06. Citado por POGENBRINSCHI, O problema da obediência em Thomas Hobbes, p. 87.

${ }^{342}$ A. E. TAYLOR, The ethical doctrine of Hobbes, p. 401.

${ }^{343}$ Cf. A. E. TAYLOR, The ethical doctrine of Hobbes, p. 415.

${ }^{344}$ A. E. TAYLOR, The ethical doctrine of Hobbes, p. 418.
} 
'lei natural' é um comando de Deus, e que deve ser obedecida porque é um comando de Deus ${ }^{345}$.

Além do fato de serem obtidas por meio da razão, as leis de natureza são comando também em conseqüência de sua origem divina:

[p]ara reconhecê-las [as leis naturais] como leis, nós devemos também saber que elas são comandos de Deus, e desde que Hobbes ensina que a lei que obriga in foro interno não é totalmente seguida a menos enquanto uma intenção formal de seguir a lei, nós não preenchemos realmente as demandas da eqüidade a menos que nós obedeçamos os comandos divinos enquanto tais, porque eles são comandos divinos ${ }^{346}$.

As teses de Taylor foram retomadas e desenvolvidas por Howard Warrender, num estudo que também se tornou clássico: The political philosophy of Hobbes: his theory of obligation. Do mesmo modo que Taylor, Warrender defende que há obrigações no estado de natureza hobbesiano, em decorrência do caráter divino da lei de natureza: "[a]ssim como em Taylor, o Hobbes de Warrender é jusnaturalista e teísta, e sua teoria da obrigação a chave de um sistema moral fundado teologicamente" ${ }^{347}$. Para que as leis naturais obriguem no estado de natureza, contudo, Warrender acrescenta a necessidade de serem cumpridas determinadas condições de validade, tendo em vista o que Hobbes afirma sobre o cumprimento das leis de natureza não poder levar os homens a tornarem-se presa fácil dos demais ${ }^{348}$. Além da segurança suficiente no cumprimento, Warrender encontra em passagens dos textos de Hobbes outras condições de validade

\footnotetext{
${ }^{345}$ A. E. TAYLOR, The ethical doctrine of Hobbes, p. 418.

${ }^{346}$ A. E. TAYLOR, The ethical doctrine of Hobbes, p. 419.

347 Thamy POGREBINSCHI, O problema da obediência em Thomas Hobbes, p. 102.

${ }^{348}$ Howard WARRENDER, The political philosophy of Hobbes: his theory of obligation, p. 78.
} 
das leis. São as seguintes: a lei deve ser conhecida ${ }^{349}$; o autor da lei deve ser conhecido $^{350}$; a lei deve ser interpretada ${ }^{351}$; e deve haver um motivo para a obediência $^{352}$. É no plano da autoria que a procedência divina garante obrigatoriedade à lei natural: “[o] autor das leis de natureza, Deus, como as próprias leis, deve ser conhecido pelo uso da razão, e apesar do nosso conhecimento de Deus por meio da razão ser incompleto, ele é suficiente para nos obrigar a obedecer a seus comandos"353. Esse conhecimento não depende de revelação, sendo passível de obtenção por meio da razão humana ${ }^{354}$. A autoria interfere drasticamente na questão da obrigação, argumenta Warrender, pois o problema não é mais saber se a lei deve ou não ser obedecida, mas se o autor da lei deve ou não ser obedecido. É nesse ponto que a presença de Deus como o autor das leis de natureza é absolutamente fundamental: “[s]e for negado que Deus possui um papel essencial na doutrina de Hobbes, as leis de natureza no estado de natureza não podem ser tomadas por mais que máximas prudenciais para aqueles que desejam sua própria preservação"355. Para Warrender, os comandos de Deus, além de possuírem a natureza de lei, dado que obrigatórios, devem ter, para serem válidos, a forma de lei ${ }^{356}$.

Um problema na interpretação de Warrender é que, se, por um lado, ela permite que certas passagens bastante complicadas - como a de que a lei de natureza não é exatamente uma lei se não possuir o atributo do comando divino - sejam compreendidas, por outro ela precisa, para se sustentar, deixar de lado outras passagens

\footnotetext{
${ }^{349}$ Howard WARRENDER, The political philosophy of Hobbes: his theory of obligation, p. 80.

${ }^{350}$ Howard WARRENDER, The political philosophy of Hobbes: his theory of obligation, p. 81.

${ }^{351}$ Howard WARRENDER, The political philosophy of Hobbes: his theory of obligation, p. 85.

${ }^{352}$ Howard WARRENDER, The political philosophy of Hobbes: his theory of obligation, p. 87.

${ }^{353}$ Howard WARRENDER, The political philosophy of Hobbes: his theory of obligation, pp. 81 e 82.

${ }^{354}$ Howard WARRENDER, The political philosophy of Hobbes: his theory of obligation, p. 82.

${ }^{355}$ Howard WARRENDER, The political philosophy of Hobbes: his theory of obligation, p. 99.

${ }^{356}$ Thamy POGREBINSCHI, O problema da obediência em Thomas Hobbes, p. 106.
} 
igualmente importantes e complicadas de Hobbes - como a de que lei natural e lei civil possuem a mesma extensão ${ }^{357}$. Ou seja, ela privilegia certos aspectos em detrimento de outros. Ela não oferece uma análise da teoria de Hobbes por inteiro.

\section{Conclusão}

Em função da insuficiência da lei natural entendida somente como preceito da razão, Hobbes garante-lhe a qualidade de lei em sentido próprio, propícia portanto ao comando e à respectiva obediência, ao dar-lhe o caráter de mandamento de Deus.

Algumas conseqüências podem ser obtidas a partir dessa constatação. A primeira é a relação que pode existir entre esses dois tipos de lei de natureza. Eles são a mesma coisa? São diferentes? Sendo diferentes, há conflito entre a lei de natureza tomada enquanto ditame racional e a lei de natureza tomada como comando divino?

Em relação à primeira questão, parece evidente, a partir dos textos de Hobbes, que lei de natureza como preceito racional não é a mesma coisa que lei de natureza como ordem de Deus. São diferentes. A rigor, lei de natureza como preceito racional não é propriamente uma lei, pois não é vinculante. Não é, entretanto, uma conclusão pacífica, dada a linguagem ambígua de Hobbes (que, como aponta Taylor, diz que o ditame racional obriga e ordena, e não apenas recomenda). Em todo caso, o próprio Hobbes é explícito ao mencionar que a lei de natureza como preceito racional não é imperativa. Diferentemente do comando de Deus.

Há, assim, uma diferença de natureza entre as duas leis de natureza. São coisas distintas. Uma é recomendação e não obriga. Outra é ordem e obriga.

\footnotetext{
${ }^{357}$ A esse respeito, Marcelo Gross VILLANOVA, Lei natural e lei civil na filosofia política de Thomas Hobbes, pp. 46, 76 e 77.
} 
Resta saber se, sendo diferentes, são conciliáveis ou não. Em outras palavras: é possível elas disporem coisas diferentes? Pode-se imaginar uma situação abstrata em que a lei de natureza como preceito da razão recomende uma coisa (que o homem não consuma vinho, por exemplo) e a lei de natureza como comando divino prescreva outra (que o homem consuma vinho). Essa situação seria encontrada no sistema de Hobbes?

Não, não seria. Pois a razão, diz o filósofo, e possivelmente ecoando a teoria dos estóicos, é divina. A razão humana, que recomenda certas condutas ao homem, foi colocada por Deus no homem. Para Hobbes, Deus deu ao homem tanto suas leis como a razão para que ele compreenda e respeite Suas leis. É por esse motivo que Hobbes esforça-se tanto em demonstrar que sua teoria da lei de natureza encontra respaldo bíblico. Há, em todos os livros sistemáticos sobre filosofia política, capítulos inteiros dedicados a aproximar as leis de natureza fundadas na razão aos comandos de Deus revelados e presentes nos textos sagrados.

Nesse sentido, o comando divino atuaria como uma garantia da validade das leis naturais obtidas pela razão. Seria mesmo um reforço delas. Tanto no sentido de sua obrigatoriedade - devem ser cumpridas não só porque são racionais, mas porque Deus manda - como para saber quais são elas - em caso de dúvida se uma prescrição é ou não lei de natureza, consultem-se as Sagradas Escrituras.

Essa “dupla definição”, contudo, não esgota a gama de significados da lei de natureza, uma vez que o filósofo ainda a trata como lei moral. É o objeto do próximo tópico. 


\subsection{Lei de natureza como lei moral}

Embora a lei de natureza muitas vezes tenha estado associada a conteúdos morais entre os jusnaturalistas, essa é uma característica menos determinante do conceito. Não foi tão discutida nem tratada tão exaustivamente pelos autores como as noções de ditame da razão e de ordem de Deus.

Entre os filósofos pré-socráticos o vínculo entre lei de natureza e conteúdos morais já estava presente:

a moralidade fundamenta-se, pois, segundo Heráclito, como segundo os pitagóricos, na lei natural. Mas o nosso conhecimento fragmentário da sua filosofia não nos permite precisar o alcance de certas fórmulas nem de que maneira conciliava o solitário pensador de Éfeso o relativismo do devir na esfera moral e jurídica, com a primazia do logos, comum a todos ${ }^{358}$.

Na filosofia de Cícero é também a lei de natureza quem determina quais os conteúdos das leis morais, quais as virtudes a serem perseguidas pelos homens. A virtude é determinada pela natureza, cabendo ao homem segui-la: “[n]ão há indivíduo, seja qual for a raça a que pertença, que não possa alcançar a virtude, seguindo a orientação da Natureza"359. A doutrina das virtudes, do conhecimento do bem e do mal, para Cícero, vem diretamente da natureza. Não é, de forma alguma, baseada em convenções humanas. "O certo e o errado são 'apreciáveis' em si mesmos"360 . E “se o bem é louvável, é porque encerra em si mesmo algo que nos obriga a louvá-lo; pois o bem não depende das convenções e sim da natureza" ${ }^{361}$.

\footnotetext{
${ }^{358}$ A. Truyol SERRA, História da filosofia do direito e do Estado, Volume I: das origens, à baixa Idade Média, p. 89.

${ }^{359}$ CÍCERO, Das leis, Livro I, § 30, p. 45.

${ }^{360}$ CÍCERO, Das leis, Livro I, § 37, pp. 47 e 48.

${ }^{361}$ CÍCERO, Das leis, Livro I, § 46, p. 51.
} 


\section{Lei de natureza como lei moral em Hobbes}

As duas concepções de lei de natureza mais fortes, essenciais para o sistema de Hobbes, são as de ditame da razão e ordem de Deus. Inclusive a maioria dos comentadores, ao enveredar pelo tema das diferentes definições de lei de natureza em Hobbes, via de regra acaba apontando para essa dupla definição ${ }^{362}$. Não obstante, Hobbes afirma que as leis de natureza são também leis morais.

De fato, a concepção de lei de natureza como lei moral não desfruta do mesmo estatuto das demais. Se a lei natural vista como preceito da razão e como comando divino é essencial para o pensamento político de Hobbes, a concepção como lei moral não é tão relevante. Mas mesmo assim Hobbes dá alguma importância para a idéia, pois trata dela nas três obras sistemáticas (não tocando no assunto, contudo, no Diálogo).

Se, por um lado, do ponto de vista da lei natural a lei moral não é um aspecto determinante, do ponto de vista da moralidade no sistema de Hobbes o tema das leis de natureza é essencial. As leis de natureza subsistem se alijadas de seu sentido de lei moral, mas a moral hobbesiana é totalmente fundamentada nas leis de natureza. $\mathrm{O}$ filósofo baseia toda a sua teoria moral nelas: “[é] partindo de sua concepção de lei natural que Hobbes aponta mais claramente para o que vai entender e definir como moralidade" ${ }^{363}$. No estado de natureza não há consenso sobre em que consistem o bem e o mal - cada homem pensa de uma maneira diferente dos demais, e a discordância acaba conduzindo às desavenças e aos conflitos. Só que "as leis naturais, no entanto, são

\footnotetext{
362 Como ZARKA e ARAÚJO, por exemplo.

${ }^{363}$ Rita Helena Sousa Ferreira GOMES, Lei natural e lei civil em Hobbes, p. 150.
} 
comuns a todos os homens, tendo em vista que são regras da reta razão"364. Se as leis naturais não são fortes o suficiente para constrangerem os homens à ação, no plano moral elas assumem o relevante papel de recomendar boas ações: "assim sendo, as leis naturais nos levam a procurar a moralidade, mas não garantem por si mesmas a permanência nesta esfera" ${ }^{, 365}$.

Hobbes lida com a questão basicamente da mesma maneira tanto nos Elementos, como no Do cidadão e no Leviatã. Após apresentar a lei de natureza como ditame racional e acrescentar que ela deve ser vista também como comando de Deus, o filósofo adiciona que ela possui ainda um caráter de lei moral. A lei natural é lei moral porque, fundamentalmente, o conteúdo de certas leis de natureza em espécie - ser justo, ser equânime, ser bom etc. - é o conteúdo da moral. Não é o conteúdo de todas as leis naturais que pode ser considerado moral, mas apenas o de parte delas:

As leis de natureza que ditam a paz são uma subclasse das leis de natureza que ditam a preservação, mas é a essa subclasse que Hobbes usualmente se refere como leis de natureza. Somente aproximadamente metade dessa subclasse de leis que ditam os caminhos para a paz são leis que ditam a prática da virtude e é essa subclasse de subclasse de lei de natureza que forma o núcleo da filosofia moral de Hobbes ${ }^{366}$.

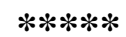

Como visto, nos Elementos Hobbes trata da lei de natureza primeiramente como preceito racional. A seguir recorre à concepção de lei divina, com

\footnotetext{
${ }^{364}$ Rita Helena Sousa Ferreira GOMES, Lei natural e lei civil em Hobbes, p. 151.

${ }^{365}$ Rita Helena Sousa Ferreira GOMES, Lei natural e lei civil em Hobbes, p. 151.

${ }^{366}$ Bernard GERT, The law of nature as the moral law, p. 28.
} 
o que as leis de natureza passam a figurar como leis propriamente ditas, ou seja, passam a dispor de força de comando. Mas, pouco depois, Hobbes afirma que a lei de natureza não é só razão e lei divina, mas é também lei moral ${ }^{367}$.

Por que as leis naturais são leis morais? São leis morais porque tratam das maneiras e da convivência dos homens uns com os outros:

As leis mencionadas nos capítulos anteriores são chamadas leis de natureza, por serem ditadas da razão natural, e também leis morais, porque dizem respeito às maneiras e à convivência dos homens uns com os outros $^{368}$.

É por tratar de certos conteúdos que a lei natural é considerada moral. Realmente, podese concluir que, para que o objetivo maior das leis de natureza - a paz e a conservação dos homens - seja alcançado, é necessário que esta paz seja mantida. E a paz é mais facilmente mantida se os homens agirem com boas maneiras e com uma convivência moralmente adequada. Em relação a esse vínculo entre lei moral e busca pela paz, logo em seguida há uma passagem corroborando-o. Hobbes defende que a lei divina e a lei moral são "os princípios que tendem para a paz"369 . Mas se esses princípios que tendem para a paz são a lei de natureza, por conseguinte deduz-se que lei natural é lei moral tanto quanto é lei divina.

Os conteúdos morais da lei de natureza aparecem quando são enunciados os preceitos em espécie. De acordo com Bernard Gert, Hobbes teria diferentes objetivos, apesar de harmônicos entre si, ao elencar as leis naturais em espécie: 1) mostrar como devem ser ditados da razão para preservar a vida; 2) mostrar quais devem ser as condições necessárias para o estabelecimento da sociedade; 3) comandar as boas

\footnotetext{
${ }^{367}$ No início do capítulo XVIII da primeira parte.

${ }^{368}$ Elementos, XVIII, § 1, p. 121.

${ }^{369}$ Elementos, XVI, § 3, p. 122.
} 
maneiras e as virtudes; e 4) mostrar que são oriundas de Deus por meio das Sagradas Escrituras $^{370}$. É no terceiro objetivo que se encontra a formulação da lei de natureza como lei moral: leis naturais são leis morais por determinarem como deve ser o bom comportamento dos homens.

Em relação às outras concepções de lei natural, não há incompatibilidade em defini-la como lei moral. "Um exame da discussão de Hobbes dessas leis [as leis de natureza em espécie] demonstra o quanto Hobbes foi bem sucedido ao mostrar que cada uma dessas leis não é apenas um ditado da razão e uma condição de paz, mas também comandos que são independentemente tidos como virtudes morais"371. Não há, com efeito, qualquer impossibilidade do conteúdo da moral ser preenchido pela racionalidade. "Nessas discussões [sobre as leis de natureza em espécie], Hobbes obtém a mais bem sucedida tentativa da literatura filosófica de mostrar que a racionalidade requer que se seja moral"372. O homem não deve agir moralmente, portanto, por motivos transcendentes, mas sim porque a ação moral, indicada pelas leis de natureza, representa o melhor caminho para sua preservação. A moral, em Hobbes, é instrumental: não tem um fim em si mesmo, mas é meio para a persecução do fim maior a ser atingido - a autopreservação.

Agir moralmente é, assim, agir tendo em vista o próprio interesse. Isso pode ser auferido não apenas a partir da concepção moral de Hobbes, mas também da análise dos preceitos da lei natural em espécie. Pode-se concluir, como faz Rita Helena Sousa Ferreira Gomes, que

Estudando o capítulo XV do Leviatã [sic!] ou do seu correspondente no Do cidadão, a saber, o capítulo que

\footnotetext{
${ }^{370}$ Bernard GERT, The law of nature as the moral law, p. 27.

${ }^{371}$ Bernard GERT, The law of nature as the moral law, p. 29.

${ }^{372}$ Bernard GERT, The law of nature as the moral law, p. 29.
} 
trata das outras leis de natureza, podemos verificar com muita nitidez o caráter prudencial destas . (...) Enfim, as virtudes aparecem não tanto como boas em si mesmas, mas como caminhos para a paz. Todavia, fica claro que o homem tem que ter estas virtudes, para poder preservar sua vida. Daí que o interesse é a base da moral $^{373}$.

Se, como visto, a conexão entre a moralidade e a racionalidade das leis de natureza é bastante forte, o mesmo não pode ser dito a respeito da relação entre a lei moral e o comando divino. Nesta relação, a moral está num lugar secundário, sendo a principal falta moral o pecado (ou seja, não cumprir o acordo ou a lei), e não um vício $^{374}$.

Além do exposto, há somente algumas passagens esparsas apontando para a lei natural como lei moral, sem grandes conseqüências ${ }^{375}$.

$* * * * *$

Em Do cidadão, a noção de lei natural enquanto lei moral é mais desenvolvida do que nos Elementos.

Diferentemente do que ocorre nos Elementos e no Leviatã, a lei moral no texto é aproximada à lei natural antes mesmo da lei divina. É mencionada quando Hobbes faz as considerações gerais após elencar as leis naturais em espécie ${ }^{376}$. O filósofo afirma que lei natural e lei moral são idênticas: “[t]odos os autores concordam que a lei natural é a mesma coisa que a moral. Vejamos por que razões isto é verdade" ${ }^{377}$. Hobbes justifica que lei moral é a mesma coisa que lei natural porque as coisas que a lei natural manda fazer (procurar bem conviver com os demais, ser bom,

\footnotetext{
${ }^{373}$ Rita Helena Sousa Ferreira GOMES, Lei natural e lei civil em Hobbes, p. 149.

${ }^{374}$ Cícero ARAÚJO, As duas definições de lei natural em Hobbes, p. 196.

${ }^{375}$ Por exemplo, no Livro II, capítulo VI, § 11, p. 69; parte II, capítulo X, § 7, p. 69.

${ }^{376}$ No capítulo III.

${ }^{377}$ Do cidadão, § 31, p. 72.
} 
ser justo etc.) são as virtudes, e as virtudes são o conteúdo da lei moral. Para a paz ser obtida, os homens precisam ter bons modos. Como ter bons modos é agir com virtude, e agir com virtude é o que manda a lei moral, segue-se que a lei natural é também lei moral. Yara Frateschi explica em termos de adequação do homem à sua natureza. $\mathrm{O}$ homem virtuoso para Hobbes (e nesse ponto concordando com Aristóteles) é aquele que realiza sua natureza. E a natureza do homem hobbesiano é a da autopreservação. O homem que se preserva é o homem que bem escuta as leis naturais. Logo, o homem virtuoso é o homem que segue as leis de natureza. "Em suma, as leis naturais são morais porque apontam as ações que conduzem à autoconservação, sendo virtuoso o homem que as seguir" ${ }^{, 378}$.

Um pouco depois, Hobbes defende que "[a] mesma lei que é natural e moral também é merecidamente chamada divina" ${ }^{\text {379 }}$. Apesar de não dizer nada especificamente sobre lei moral na seqüência, fica clara a identificação da lei natural tanto com a lei moral quanto com a lei divina.

Quando o filósofo enumera as leis naturais em espécie, e demonstra que elas estão também presentes nos textos bíblicos, trata outra vez da concepção de lei moral. Na nona lei de natureza, que lida com a eqüidade, Hobbes afirma que ela corresponde ao preceito de "amar o próximo como a ti mesmo". Esse preceito, prossegue o autor, equivale, nas palavras de Jesus, à "suma da lei moral" 380 . Encontrase, assim, outra vez demonstrada a ligação entre a racionalidade, expressa aqui na regra de reciprocidade, e a moralidade da lei de natureza.

\footnotetext{
${ }^{378}$ Yara FRATESCHI, Estado e direito em Thomas Hobbes, p. 310.

${ }^{379}$ Do cidadão, no capítulo seguinte (o IV, que se chama, a propósito, 'Que a lei de natureza é lei divina'), § 1, p. 75.

${ }^{380}$ Do cidadão, p. 81.
} 
Depois Hobbes trata da lei moral somente de modo esporádico. Por exemplo, ao cuidar do tema dos deveres do soberano, defende que a razão reta é a lei natural, a lei moral e a lei divina ${ }^{381}$. Também, posteriormente, afirma numa passagem bem ilustrativa que a lei natural é a mesma coisa que virtude moral:

Como a palavra de Deus, em seu reino natural, é tãosomente a razão reta (assim, pelo menos, se supõe), e como por outro lado as leis dos reis apenas podem ser conhecidas pelas palavras deles, evidencia-se então que as leis de Deus, quando ele reina tão-só naturalmente, nada mais são que as leis naturais, ou seja, aquelas que expusemos nos capítulos II e III, e que deduzimos dos ditames da razão - a humildade, a eqüidade, a justiça, a misericórdia, e outras virtudes morais favoráveis à paz, que mandam os homens cumprirem seus deveres uns para com os outros -, e ainda aquelas que a razão reta acrescentar, a propósito da honra e culto devidos à Majestade Divina. Não precisamos repetir quais são essas leis naturais ou virtudes morais; mas devemos investigar o que a mesma razão natural dita no tocante às honras e ao culto divino, isto é, que leis sacras ela determina ${ }^{382}$.

Pouco depois, Hobbes defende ainda que o que ele apresentou nos capítulos anteriores (ou seja, as leis de natureza em espécie) são leis morais: “[d]o que afirmamos se pode concluir que, quando Deus reina apenas pela via da razão natural, seus súditos pecam, em primeiro lugar, se violam as leis morais, que nós desenvolvemos nos capítulos II e III"383. As leis morais são, assim, colocadas por Hobbes como sendo o mesmo que as leis naturais. Isso por dois motivos: primeiramente, porque são identificadas às leis da

\footnotetext{
${ }^{381}$ Do cidadão, XIII, § 2, p. 198.

${ }^{382}$ Do cidadão, XV, § 8, p. 245.

${ }^{383}$ Do cidadão, XV, § 19, p. 260.
} 
razão dadas por Deus ao homem; em segundo lugar, porque são as mesmas que as leis de natureza em espécie enumeradas nos capítulos II e III.

No final da obra, ao dizer o que é preciso fazer para ir para o reino dos céus, Hobbes oferece uma boa descrição da lei moral:

como quem ama a Deus não pode deixar de sentir o desejo de obedecer à lei divina, e quem ama a seus próximos não pode deixar de sentir um desejo de obedecer a lei moral, que consiste - conforme já mostramos acima, no capítulo III - na proibição da arrogância, da ingratidão, da contumélia, da desumanidade, da crueldade, da injúria e de outras ofensas análogas, pelas quais prejudicamos ao próximo, por conseguinte também o amor ou caridade é equivalente à obediência. E também a justiça, que consiste na vontade constante de dar a cada homem o que lhe é devido, lhe é equivalente ${ }^{384}$.

A descrição, aqui, não é conceitual, mas exemplificativa. Ao se analisar a passagem, percebe-se novamente que as leis morais em espécie são justamente as leis naturais em espécie.

A primeira vez que a lei natural aparece vinculada aos preceitos morais no Leviatã (apesar de Hobbes não usar ainda a expressão "lei moral") é quando são feitas as considerações gerais no final do tratamento das leis naturais em espécie. $\mathrm{O}$ filósofo defende que a ciência das leis naturais é a "verdadeira e única filosofia moral. Porque a filosofia moral não é mais do que a ciência do que é bom e mau, no convívio e na sociedade humana" ${ }^{385}$. É a mesma idéia expressa no Do cidadão, mas de maneira

\footnotetext{
${ }^{384}$ Do cidadão, XVIII, § 3, p. 331.

${ }^{385}$ Leviatã, XV, § 40, p. 136.
} 
ainda não desenvolvida. Logo depois, explicando, Hobbes repete que "a verdadeira doutrina das leis de natureza é a verdadeira filosofia moral"386.

Note-se que Hobbes, contrariamente ao Do cidadão, demora a usar a expressão lei moral. Ao desenvolver o tema das leis civis ${ }^{387}$, também não a utiliza desde os primeiros momentos. Não obstante, trata das virtudes morais da lei de natureza quando repete, para igualar lei natural a lei civil, o que havia afirmado sobre lei natural não ser lei em sentido próprio $^{388}$ :

Porque as leis de natureza, que consistem na eqüidade, na justiça, na gratidão e outras virtudes morais destas dependentes, na condição de simples natureza (conforme já disse, no final do capítulo XV) não são propriamente leis, mas qualidades que predispõe os homens para a paz e a obediência ${ }^{389}$.

Hobbes usa aqui o conteúdo moral das leis de natureza para defender que elas, se tomadas apenas como preceitos racionais, não são exatamente leis. O conteúdo moral apenas predispõe o homem para a obediência, mas não o obriga. Sendo assim, "[s]e não há uma lei geral da moral, segue-se que os desejos e paixões do homem não são censuráveis em si mesmos. E também não são as ações que procedem dessas paixões, até que haja uma lei que as proíba" ${ }^{390}$.

A expressão lei moral aparece apenas posteriormente, na parte relativa às leis civis $^{391}$. Nela, Hobbes apresenta divisões das espécies de lei, em uma delas

\footnotetext{
${ }^{386}$ Leviatã, XV, § 40, p. 137.

${ }^{387}$ No capítulo XXVI.

${ }^{388}$ Leviatã, XV.

${ }^{389}$ Leviatã, XXVI, § 8, p. 227.

${ }^{390}$ CAIRNS, Huntington. Hobbes' theory of law, p. 63.

${ }^{391}$ No capítulo XXVI.
} 
classificando-as em naturais e positivas. Nesse momento registra que as leis naturais são as leis morais.

Outra maneira de dividir as leis é em naturais e positivas. As naturais são as que têm sido leis desde toda a eternidade, e não são apenas chamadas naturais, mas também leis morais. Consistem nas virtudes morais, como a justiça, a eqüidade, e todos os hábitos de espírito propícios à paz e à caridade, dos quais já falei nos capítulos XIV e XV $\mathrm{XV}^{392}$.

As leis morais, como visto, não são portanto uma espécie própria de lei, mas sim a mesma coisa que as leis naturais, se estas forem tomadas em relação ao conteúdo de seus preceitos. No tocante a essa classificação das espécies de leis, Hobbes efetua algumas alterações em relação à tradição do direito natural:

[a] filosofia jurídica e especulativa antes de Hobbes distinguia vários tipos de lei. Havia não apenas um ius naturale, um ius gentium e um ius civile, mas também um ius naturale prius, um ius naturale posterius e um ius gentium praevium e um ius gentium secundarium (...). $\mathrm{O}$ primeiro passo de Hobbes foi eliminar algumas dessas importantes categorias e revisar o esquema classificatório geral $^{393}$.

A mesma noção é usada por Hobbes para defender que os súditos não devem desobedecer ao soberano se suas ordens não forem contrárias às leis naturais: “[c]oncluo portanto que, em tudo o que não seja contrário à lei moral (quer dizer, à lei de natureza), todos os súditos são obrigados a obedecer como lei divina ao que como tal

\footnotetext{
${ }^{392}$ Leviatã, XXVI, § 37, p. 242.

${ }^{393}$ CAIRNS, Huntington. Hobbes' theory of law, p. 66.
} 
for declarado pelas leis da república"394. A lei moral, aqui, é dada como sinônimo perfeito de lei de natureza, sendo ambas tomadas enquanto leis divinas.

Por fim, na parte final, relativa à religião, Hobbes menciona, numa passagem, que as ordens de Deus são leis morais. Abraão fez o primeiro pacto com Deus, pelo qual iria

reconhecer e obedecer às ordens de Deus, não apenas aquelas de que tinha conhecimento (como as leis morais) pela luz da natureza, mas também aquelas que Deus lhe comunicasse de maneira especial por sonhos e visões. Pois quanto à lei moral, estavam já obrigados e não precisavam fazer contrato, pela promessa da terra de Canaa ${ }^{395}$.

Interessante notar que o filósofo utiliza lei moral como sinônimo de lei natural (da mesma forma que anteriormente ${ }^{396}$ ).

\section{Interpretações}

Devido à menor relevância que o tema da lei moral ocupa no sistema político hobbesiano, não há ainda um corpo de estudos que examinam especificamente a questão. Há passagens isoladas em textos de comentadores que tratam de outros assuntos, mas sem grandes desdobramentos.

\section{Conclusão}

Preceito da razão, comando de Deus e lei moral são os diferentes sentidos que Hobbes atribui à lei de natureza. Além deles, o filósofo faz ainda algumas relações entre a lei natural e a lei civil, colocando ambas eventualmente como a mesma coisa.

\footnotetext{
${ }^{394}$ Leviatã, XXVI, § 41, p. 245.

${ }^{395}$ Leviatã, XL, p. 394.

${ }^{396}$ Leviatã, p. 344.
} 
Esse caráter de lei civil que a lei de natureza por vezes adquire será tratado nas relações entre as duas leis. 


\section{Lei civil em Hobbes}

No sistema político-jurídico de Hobbes, após a instituição do Estado soberano, este passa a zelar pela garantia da paz e da preservação de seus membros. Sua função, impulsionado pela lei de natureza que determina a busca da paz e da preservação, é colocar fim à insegurança presente no belicoso estado de natureza. Deve garantir a ordem - e faz isso por meio de suas determinações. Tais determinações são as leis civis:

Pode-se dizer que a função essencial do soberano legislador é a de fazer surgir, ao mesmo tempo que uma ordem moral, uma ordem jurídica na qual a fonte viva não é mais, como era na tradição aristotélica, a natureza das coisas, mas sim a vontade e a razão prática dos homens sabendo, por cálculo utilitário, criar os modos de escapar da violência dos instintos ${ }^{397}$.

O tema da lei civil é tratado por Hobbes em todos os seus escritos políticos. Neles, o filósofo aparentemente acaba novamente dando mais de um sentido para a mesma expressão: ora trata a lei civil como comando do soberano, ora como medida das ações dos súditos e ora como lei natural. O objetivo do presente capítulo é apresentar de que forma as duas primeiras figurações (como comando do soberano e como medida das ações dos súditos) aparecem nos textos analisados. A identificação entre lei civil e lei natural é objeto de capítulo próprio.

As duas definições, diga-se desde já, não são em nenhum momento conflitantes. Mais que isso, são complementares. O caráter de comando do soberano de modo algum exclui o caráter de medida das ações dos súditos - muito pelo contrário, é

\footnotetext{
${ }^{397}$ Simone GOYARD-FABRE, Le droit et la loi dans la philosophie de Thomas Hobbes, p. 140.
} 
justamente por ser uma ordem emanada por quem possui força e direito para tanto que a lei civil deve guiar as ações dos súditos.

Apesar dessa complementaridade entre os conceitos, Hobbes os analisa e aplica por vezes separadamente, opção seguida nesta dissertação.

Além da identificação da lei civil com as ordens dos governantes e com as ações dos governados, em alguns momentos Hobbes aproxima a noção da lei de natureza. Em razão da relevância e das complicações que envolvem essa aproximação, as relações entre lei civil e lei de natureza são vistas em capítulo próprio.

Em comparação com a lei natural, os problemas que envolvem a adequada delimitação do conceito de lei civil são muito mais amenos. Se a lei natural era um conceito fugidio, definido de diferentes maneiras e passível de intermináveis discussões entre os comentadores, a lei civil apresenta-se muito mais facilmente estabelecida, não dando margem a tantas controvérsias. 


\subsection{Lei civil como comando do soberano}

A idéia que associa o direito (ou lei) ao comando é muito recorrente. $\mathrm{Na}$ Antígona, por exemplo, fica claro que um dos sentidos de lei a ser seguida, em contraste com as regras imemoriais, é composto pelas ordens emanadas pelo rei.

Na Idade Média a noção de que lei é comando também estava presente.
A mais influente versão medieval dessa posição, combinando elementos de Cícero e de Aristóteles e de outros Padres da Igreja foi feita no século XIII por Tomás de Aquino. Ele definiu lei como ordenação da razão, para o bem comum, feita pela comunidade ou pela pessoa que tem comando na comunidade e promulgada. Leis postas que não tenham uma ou mais dessas características não são realmente leis ${ }^{398}$.

Grócio, no primeiro livro do Direito da guerra e da paz, procura estabelecer os sentidos que a palavra ius pode ter. O jurista identifica três: direito como justo, direito como faculdade ou aptidão e direito como regra ou comando (como lex). Para Grócio, o direito visto enquanto regra não é simplesmente um preceito, mas sim um preceito que obriga. Esta regra é composta tanto pela lei natural (que é objeto da razão) como pela lei voluntária. A lei voluntária, por sua vez, é dividida em lei humana e lei divina, sendo a lei humana subdividida em lei civil (a emanada pelo Estado), lei menos extensa que a civil (como a ordem dada por um senhor) e lei mais extensa que a lei civil (presente no direito das gentes ou direito das nações) ${ }^{399}$.

Para Hobbes, entretanto, não basta ser apenas comando ou ordem. A lei civil precisa ser um comando emanado pelo poder soberano. E a noção de soberania é, no tempo de Hobbes, relativamente recente.

\footnotetext{
${ }^{398}$ M. M. GOLDSMITH, Hobbes on law, p. 286, citando a Suma teológica, I-II, qu. 90, art. 4, p. 17.

${ }^{399}$ Hugo GRÓCIO, Direito da guerra e da paz, livro primeiro, capítulo I, p. ???.
} 


\section{Lei civil como comando do soberano em Hobbes}

O conceito de lei civil como comando do soberano é o que mais se aproxima da definição hobbesiana de lei: quando conceitua lei em sentido mais amplo e geral (e não algum tipo específico de lei), o autor a coloca sempre como uma espécie do gênero comando: "toda lei se apresenta como um comando"400. Essa identificação da lei com o comando é, inclusive, causa das discussões acerca da qualidade precisa de lei que a lei de natureza adquire (ou não). Lei, para Hobbes, é comando.

Mas existem diferentes espécies de lei. "Consideradas em sua natureza

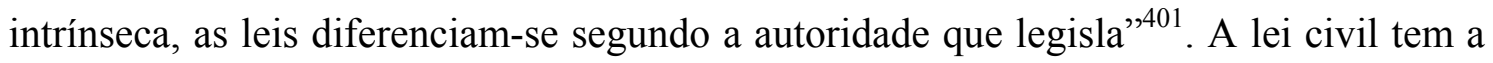
especificidade de ser um comando emanado por um autor específico, o soberano civil. Ela "enuncia uma regra prescritiva que emana de uma autoridade e impõe obrigação" O poder de editar um tipo de leis - as leis civis - é uma das marcas do poder soberano na filosofia hobbesiana. O soberano, para bem executar sua missão (qual seja, a de garantir a segurança dos súditos), concentra em si os poderes econômico, político, militar, judiciário e legislativo ${ }^{403}$. O soberano precisa legislar principalmente em função da fragilidade da lei natural - se ela não passa de um ditame, de uma recomendação, ela não pode obrigar à ação. A lei capaz de efetivamente obrigar, se não no plano da consciência, mas ao menos no plano da ação, é a lei civil. As duas leis, natural e civil, são, nesse ponto, complementares: uma (a lei natural) obriga em consciência, mas não obriga à ação, ao passo que a outra (a lei civil) não obriga em consciência, mas obriga à ação.

\footnotetext{
${ }^{400}$ Simone GOYARD-FABRE, Le droit et la loi dans la philosophie de Thomas Hobbes, p. 166.

${ }^{401}$ Simone GOYARD-FABRE, Le droit et la loi dans la philosophie de Thomas Hobbes, p. 167.

${ }^{402}$ Simone GOYARD-FABRE, Le droit et la loi dans la philosophie de Thomas Hobbes, pp. 166 e 167.

${ }^{403}$ Rita Helena Sousa Ferreira GOMES, Lei natural e lei civil em Hobbes, p. 154.
} 
É tarefa do poder soberano criar leis civis pois é ele quem tem força suficiente para garantir o seu cumprimento. A lei civil é, para Hobbes, reflexo do poder de constrangimento que somente o soberano pode possuir no Estado civil. "De acordo com Hobbes, somente o Estado (ou república) pode fazer leis e 'o legislador de todas as repúblicas somente é o soberano",404. São os sinais do soberano que são considerados leis ${ }^{405}$. Pode-se afirmar, nesse sentido, que "para Hobbes, como pouco antes para Bodin, a soberania manifesta seu poder pelo exercício de seu poder legislador em todos os domínios: que o soberano, determinando o justo, conhece e decide todos os litígios , faz-se assim mestre do poder judiciário" ${ }^{, 406}$. Ou seja: o soberano é quem faz a lei; e a lei é o que é feita pelo soberano - dos dois lados a questão se fecha na soberania.

então, parece que a soberania liga-se, em essência, à qualidade de ser mestre absoluta do direito humano. Uma vez que o Estado civil ou república são instituídos, não há outro direito além do direito do Estado: um direito que, filho da lei civil, é não somente um direito positivo, mas um direito que 'estabelecido humanamente' com o contrato social, decorre, em última análise, da vontade que preside a Commonwealth ${ }^{407}$.

Para ser eficiente, ou seja, para conseguir adequadamente manter os homens em paz e fazer valer as leis de naturais, a soberania, em Hobbes, precisa de alguns atributos. Ela deve ser não apenas suprema, mas também ilimitada: "pois uma autoridade ser a maior autoridade num sistema é uma coisa; e não haver limites acima de sua jurisdição é outra"408. De acordo com Goldsmith, há dois princípios na concepção hobbesiana de soberania. O primeiro está na noção de hierarquia: leis e

\footnotetext{
${ }^{404}$ M. M. GOLDSMITH, Hobbes on law, p. 277, citando o Leviatã, cap. XXVI, p. 137.

${ }^{405}$ M. M. GOLDSMITH, Hobbes on law, p. 277.

${ }^{406}$ Simone GOYARD-FABRE, Le droit et la loi dans la philosophie de Thomas Hobbes, p. 139.

${ }^{407}$ Simone GOYARD-FABRE, Le droit et la loi dans la philosophie de Thomas Hobbes, p. 140.

${ }^{408}$ M. M. GOLDSMITH, Hobbes on law, p. 278.
} 
autoridades estão numa ordem hierárquica, retirando a lei ou autoridade inferior sua validade da lei ou autoridade superior. O segundo princípio reside na condição de que “o sistema hierárquico termina com uma autoridade final acima da qual não se pode mais apelar - é o princípio do fechamento [closure]”,409.

$\mathrm{Na}$ primeira obra política de Hobbes, os Elementos, o tratamento da lei civil enquanto comando do soberano não possui muito destaque, não obstante a noção de lei como comando aparecer solidamente na definição de lei em geral.

Em Do cidadão, no Leviatã e no Diálogo, contudo, as formulações de lei civil como comando do soberano são mais fortes e freqüentes. É uma das poucas situações, dentre os temas abordados nesta dissertação, em que há diferenças mais significativas entre os conteúdos dos diferentes livros.

O tratamento que Hobbes dispensa à lei civil enquanto comando do soberano nos Elementos é um tanto precário. A noção aparece pouquíssimas vezes, mas nem por isso é completamente irrelevante.

A idéia de lei como comando aparece na própria definição de lei em geral. A lei é definida justamente como uma espécie do gênero comando ${ }^{410}$. É em função disso que se pode afirmar que “[a]definição de lei de Hobbes claramente faz dele um teórico do comando [command theorist]"411. No último capítulo, ao novamente definir lei, não a coloca expressamente como um comando, mas como uma declaração

\footnotetext{
${ }^{409}$ M. M. GOLDSMITH, Hobbes on law, p. 278. Goldsmith ainda compara essa norma final com a norma fundamental de Kelsen.

${ }^{410}$ Elementos, capítulo XIII da primeira parte, § 6, p. 69.

${ }^{411}$ M. M. GOLDSMITH, Hobbes on law, p. 274.
} 
da mente que trata de ações futuras ${ }^{412}$ - o que não exclui o caráter de comando, que é um dos tipos de declaração da mente.

A definição de lei civil é dada logo no início da parte II da obra. Mesmo que não a coloque precisamente como um comando do soberano, é patente que é o poder soberano que a publica e a torna conhecida ${ }^{413}$. Ou seja, mesmo que Hobbes não a defina como um comando do soberano, afirma que ela é emanada dele. Que a lei seja um comando do soberano pode ser inclusive subentendido a partir da definição de lei geral enquanto comando. Hobbes defende ainda, na mesma definição, que as leis civis cabem a quem tem o poder da espada ${ }^{414}$. Ou seja, ao soberano. Como conseqüência, "Hobbes afirma, contra Aristóteles e como Grócio, que o governo das leis é o governo dos homens"415. A lei não vale por si mesma - quem determina a lei é o homem que possui poder para editá-la e garantir seu comprimento.

É importante destacar que a definição como emanação do soberano, neste ponto do texto, é sempre dada enquanto medida das ações dos súditos (característica que, como vista adiante, prepondera nos Elementos). As duas formulações, emanação do soberano e medida das ações dos súditos, andam sempre juntas.

Além desse ponto mais central, a lei como ato do soberano aparece mais algumas vezes no texto, todas sem grandes conseqüências. Assim, ao cuidar das características da soberania, Hobbes afirma que o poder soberano é, entre outras coisas, exatamente aquele que pode fazer leis civis ${ }^{416}$. Lei civil, portanto, como um atributo do poder soberano.

\footnotetext{
${ }^{412}$ Elementos, capítulo X da segunda parte, $\S 1$ p. 69

${ }^{413}$ Parte II, capítulo I, $\S 10$, p. 69.

${ }^{414}$ A esse respeito, cf. MAQUIAVEL, O príncipe, cap. 13.

${ }^{415}$ Simone GOYARD-FABRE, Le droit et la loi dans la philosophie de Thomas Hobbes, p. 172.

${ }^{416}$ Parte II, capítulo I, $\S 19$, p. 69.
} 
Essa atividade de elaborar leis como prerrogativa do poder soberano aparece novamente em outra passagem ${ }^{417}$, na qual Hobbes deixa bastante claro que a lei é mesmo um comando, e não uma convenção. A lei é, aqui, o comando que possui em si a razão para acatarmos a ordem comandada.

Se nos Elementos a lei civil como ordem do soberano não desfruta de muito destaque, preponderando a noção de medida para a ação dos súditos, em Do cidadão o aspecto de comando é muito mais forte.

Quando Hobbes relaciona reta razão e lei natural, ele acaba, numa nota, apontando a lei civil exatamente como a razão do soberano ${ }^{418}$.

As leis civis, contudo, são definidas apenas no momento em que Hobbes lida com os direitos do soberano ${ }^{419}$. Entre seus poderes está o de legislar. Para tratar da legislação Hobbes define as leis civis. E as define como sendo as regras comuns para cada um saber o que é certo e o que é errado (ou seja, leis civis como medida), dadas ao público pelo poder principal, consistindo-se em "ordens de quem possui o poder supremo na cidade" ${ }^{420}$. Na seqüência, resume o que afirmara pouco antes: "[e] as leis civis assim as definimos: nada mais são do que as ordens de quem tem autoridade principal na cidade, dirigindo as ações futuras dos cidadãos" ${ }^{, 421}$. Ou seja, ao definir expressamente as leis civis Hobbes acaba as tratando, diferentemente do que ocorre nos Elementos, preponderantemente como ordens do portador da autoridade soberana.

\footnotetext{
${ }^{417}$ Parte II, capítulo VIII, § 6, p. 69.

${ }^{418}$ Do cidadão, capítulo II, nota III.

${ }^{419}$ Do cidadão, capítulo VI.

${ }^{420}$ Do cidadão, p. 106.

${ }^{421}$ Do cidadão, p. 106.
} 
A noção é trabalhada diversas vezes no capítulo. Logo em seguida o filósofo volta a estabelecer a lei civil como "as ordens do homem ou conselho a quem está submetido o poder supremo" ${ }^{\natural 22}$. Pouco a seguir, afirma ainda que as ordens do governante supremo são leis ${ }^{423}$. Numa nota acerca desse ponto, Hobbes expõe a mesma idéia: "a lei é a declaração de vontade do soberano" ${ }^{424}$. E, mais uma vez, as palavras do autor não deixam dúvida: "leis civis, isto é, pelas ordens daquele que possui a autoridade soberana" 425 . Com isso, tem-se firmemente estabelecido que o caráter de comando do soberano é bem mais acentuado no texto de Do cidadão.

A obra possui um capítulo específico sobre leis e crimes ${ }^{426}$. Nesse ponto, Hobbes inicia diferenciando lei de costume. E, para isso, acaba apresentando novamente uma definição de lei, que se trata justamente do preceito dado pelo soberano ao súdito (mesmo que aqui ele use terminologia diferente):

Assim é que os preceitos ditados por Deus aos homens, pelos magistrados aos súditos, e de modo geral todos os que são ditados por quem tenha poder àqueles que não lhes podem resistir, podem ser adequadamente denominados suas leis ${ }^{427}$.

Pouco a seguir, ao diferenciar lei de contrato, com o objetivo de combater Aristóteles, Hobbes destaca que lei é uma ordem: “Aristóteles deveria, pois, assim definir a lei civil como um discurso, cujos termos são definidos pela vontade da cidade, ordenando tudo o que deve ser feito"428. E ainda "[e]sta é a mesma definição que demos acima, no capítulo VI, parágrafo 9, segundo a qual as leis civis são a ordem

\footnotetext{
${ }^{422}$ Do cidadão, p. 107.

${ }^{423}$ Do cidadão, p. 111.

${ }^{424}$ Do cidadão, p. 374.

${ }^{425}$ Do cidadão, p. 113.

${ }^{426} \mathrm{O}$ capítulo XIV.

${ }^{427}$ Do cidadão, pp. 215 e 216.

${ }^{428}$ Do cidadão, p. 217.
} 
daquele (seja ele um indivíduo ou um grupo de homens) que detém o poder supremo na cidade, regulando as ações futuras de seus súditos" ${ }^{\text {429. }}$.

Um ponto interessante é que, em Do cidadão, Hobbes em diversas ocasiões coloca a lei civil apenas como ordem do legislador, deixando de lado o aspecto de medida. Por exemplo, na seguinte passagem: "[a] lei é a ordem do legislador, e essa ordem é a manifestação de sua vontade: não há portanto lei, a menos que se manifeste a vontade do legislador, o que ele faz promulgando-a" ${ }^{\natural 30}$. É bem o contrário do que ocorre nos Elementos, que têm na medida das ações do súdito o aspecto principal da lei civil.

Por fim, Hobbes utiliza pela última vez a idéia de lei civil como ordem do soberano na parte da obra que trata de religião, mais especificamente para determinar de que modo Deus dá a conhecer suas leis aos homens, na medida em que "os mandamentos dos governantes são as leis dos governados",431.

O tratamento dispensado por Hobbes à lei civil no Leviatã está mais próximo de Do cidadão do que dos Elementos. Nele, o aspecto de ordem do governante prepondera frente ao caráter de medida das ações dos governados.

$\mathrm{Na}$ introdução ao Leviatã, Hobbes compara o homem natural ao Leviatã, homem artificial. A cada parte do corpo do homem natural corresponde uma parte do Estado civil. E as leis civis são comparadas à vontade artificial do poder soberano ${ }^{432}$.

No Leviatã, Hobbes demora a tratar do tema da lei civil. Só detém-se sobre ela no capítulo próprio dedicado ao assunto. Não obstante, anteriormente já coloca

\footnotetext{
${ }^{429}$ Do cidadão, pp. 217 e 218.

${ }^{430}$ Do cidadão, p. 225.

${ }^{431}$ Do cidadão, pp. 240 e 241.

${ }^{432}$ Leviatã, p. 69
} 
a lei geral em termos de comando, na passagem bastante complicada em que afirma que as leis de natureza não são exatamente leis se vistas apenas como recomendações racionais:

A estes ditames da razão os homens costumam dar o nome de leis, mas impropriamente. Pois eles são apenas conclusões ou teoremas relativos ao que contribui para a conservação e defesa de cada um, enquanto a lei, em sentido próprio, é a palavra daqueles que tem o direito de mando sobre os outros. No entanto, se considerarmos os mesmos teoremas como transmitidos pela palavra de Deus, que tem direito de mando sobre todas as coisas, nesse caso serão propriamente chamados leis ${ }^{433}$.

Apesar de ter tomado lei civil como medida anteriormente (passagem do capítulo XVIII analisada em local próprio), no capítulo dedicado à lei civil Hobbes a define em termos de comando do soberano. São, curiosamente, duas definições. O autor começa o capítulo XXVI, sobre lei civil, afirmando o que ele entende a respeito do conceito: "[e]ntendo por LEIS CIVIS aquelas leis que os homens são obrigados a respeitar, não por serem membros desta ou daquela república em particular, mas por serem membros de uma república"434. Não é ainda explicitamente uma ordem do soberano, noção inserida pelo filósofo na seqüência imediata do texto: “[e] em primeiro lugar é evidente que a lei, em geral, não é um conselho, mas uma ordem"435. A concepção de ordem ou comando é trazida justamente porque a lei civil participa da definição mais ampla de lei em geral. Após inserir o elemento imperativo, Hobbes coloca a competência para o mando (ou seja, quem é que pode dar a ordem): “[e]

\footnotetext{
${ }^{433}$ Leviatã, p. 137.

${ }^{434}$ Leviatã, p. 225.

${ }^{435}$ Leviatã, p. 226.
} 
também não é ordem dada por qualquer um a qualquer um, pois é dada por quem se dirige a alguém já anteriormente obrigado a lhe obedecer" ${ }^{\text {"46 }}$. Com isso, já estão dados os elementos para uma definição propriamente dita:

Considerando isto, defino a lei civil da seguinte maneira: A LEI CIVIL é para todo súdito constituída por aquelas regras que a república lhe impõe, oralmente ou por escrito, ou por outro sinal suficiente da sua vontade, para usar como critério de distinção entre o bem e o mal, isto é, do que é contrário à regra ${ }^{437}$.

Esta segunda definição, mais completa, já incorpora a medida como aspecto da lei civil.

A seguir, o filósofo desenvolve algumas explicações a respeito da definição de lei civil. Hobbes deixa claro que a lei civil é uma ordem do soberano (e de mais ninguém): “[e] igualmente que ninguém pode fazer leis a não ser o Estado, pois a nossa sujeição é unicamente para com a república"438. No parágrafo seguinte deixa novamente bastante clara a mesma idéia: “[p]orque o legislador é aquele que faz a lei, e apenas a república prescreve e ordena a observância daquelas regras a que chamamos leis. Portanto, a república é o único legislador»"439.

Ao desenvolver o tema da lei civil, Hobbes traz uma série de explicações complementares a respeito dela. Ao tratar da racionalidade da lei, acaba determinando a lei justamente como ordem dada pelo legislador: "[p]ortanto, o que faz a lei não é aquela juris prudentia, ou sabedoria dos juízes subordinados, mas a razão deste nosso

\footnotetext{
${ }^{436}$ Leviatã, p. 226.

${ }^{437}$ Leviatã, p. 226.

${ }^{438}$ Leviatã, p. 226.

${ }^{439}$ Leviatã, p. 226.
} 
homem artificial, a república, e suas ordens" ${ }^{\$ 40}$. Ou seja, a lei civil é ordem do soberano e de mais ninguém, nem mesmo dos seus subordinados ${ }^{441}$.

Assim como a lei natural vista como lei divina depende da vontade de Deus, a lei civil vista como ordem do soberano depende da vontade do soberano. De modo que o que dá força à lei civil não é o costume e nem a sabedoria, mas sim a autoridade: "[a]s leis civis não dependem da razão, e sim da vontade do soberano"442. Ou seja: é melhor que as leis civis estejam de acordo com a reta razão, mas não é necessário. Não obstante, antes disso, obedecer às leis civis, por estranhas que sejam, é sempre racional: pois a razão diz aos homens que é obedecendo-as que eles irão preservar-se da guerra. Não se deve, dessa maneira, desobedecer ao soberano, mesmo quando sua ordem parece ir contra o fim pelo qual o Estado civil foi estabelecido. Por quê? Porque, uma vez instituído o Estado civil, quem decide o que é contrário ou favorável à paz não é o súdito, mas sim o soberano. Os cidadãos abriram mão do seu julgamento, em prol do julgamento do soberano, para que a paz fosse possível. Daí não ser possível, no sistema de Hobbes, uma justificativa para rebeliões ou resistência contra o poder soberano fundadas na consciência individual dos cidadãos.

A lei civil tomada enquanto comando do poder supremo aparece novamente na consideração seguinte, a respeito de que só pode seguir a lei quem dela for devidamente informado:

8. Partindo daqui, de que a lei é uma ordem, e de que uma lei consiste na declaração ou manifestação da vontade de quem ordena, oralmente ou por escrito, mediante outros suficientes argumentos da

\footnotetext{
${ }^{440}$ Leviatã, p. 230.

${ }^{441}$ Nesse ponto, Hobbes discorda de Maquiavel, para quem "leis civis nada mais são que sentenças proferidas pelos antigos jurisconsultos, sentenças que, ordenadas, ensinam nossos jurisconsultos a julgar" (Discursos sobre a primeira década de Tito Lívio, L. I, proêmio, p. 6).

${ }^{442}$ Rita Helena Sousa Ferreira GOMES, Lei natural e lei civil em Hobbes, p. 158.
} 
mesma vontade, podemos compreender que a ordem da república só é lei para aqueles que têm meios para dela se informarem ${ }^{443}$.

A explicação coloca, entre outras coisas, a lei novamente como um comando:

Em primeiro lugar, se for uma lei obrigatória para todos os súditos sem exceção, e não estiver escrita ou de algum outro modo publicada em lugares onde se possam informar, trata-se de uma lei de natureza. Porque tudo o que os homens conhecem como lei, não pelas palavras de outros homens, mas cada um através da sua própria razão, deve ser válido para a razão de todos os homens, o que não pode acontecer com nenhuma lei, a não ser a lei de natureza. Portanto, as leis de natureza não precisam ser públicas nem proclamadas, pois estão contidas nesta única sentença, aprovada por toda gente: Não faças aos outros o que não considera razoável que seja feito por outrem a ti mesmo ${ }^{444}$.

Ao final dessas observações a respeito da definição de lei, Hobbes aponta mais uma vez a lei como sinal de vontade do soberano: “[e] não basta que a lei seja escrita e publicada, é preciso também que haja sinais manifestos de que ela deriva da vontade do soberano" ${ }^{445}$. Não é suficiente que a lei civil seja uma ordem do soberano é necessário que se possa saber que ela é ordem do soberano. Deve ser publicada de alguma maneira. Por dever ser publicada, deve ser positivada. Para Hobbes, lei civil é, portanto, lei positiva ${ }^{446}$.

\footnotetext{
${ }^{443}$ Leviatã, p. 230.

${ }^{444}$ Leviatã, p. 231.

${ }^{445}$ Leviatã, p. 232.

${ }^{446}$ Simone GOYARD-FABRE, Le droit et la loi dans la philosophie de Thomas Hobbes, p. 168.
} 
No mesmo capítulo sobre leis civis, Hobbes apresenta os diferentes tipos de divisões de leis. Uma das divisões possíveis é entre as leis naturais e as leis positivas. Ao explicar o que são leis positivas, afirma que

$$
\begin{aligned}
& \text { As positivas são as que não existem desde toda a } \\
& \text { eternidade, e foram tornadas leis pela vontade } \\
& \text { daqueles que tiveram o poder soberano sobre } \\
& \text { outros. Podem ser escritas, ou então dadas a } \\
& \text { conhecer aos homens por qualquer outro } \\
& \text { argumento da vontade do seu legislador }{ }^{447} \text {. }
\end{aligned}
$$

Novamente, é expresso que a vontade do soberano legislador deve ser conhecida de algum modo.

Após desenvolver especificamente a lei civil, em capítulo próprio, como visto, Hobbes menciona em algumas outras passagens o caráter de mando da lei. Por exemplo, na terceira parte do livro, sobre o Estado cristão, há um trecho na discussão sobre poder eclesiástico que fala na lei como ordem do soberano:

Que o novo Testamento seja canônico neste sentido, quer dizer, seja lei em qualquer lugar onde a lei da república assim não o fez, é contrário à natureza da lei. Porque uma lei (conforme já foi mostrado) é a ordem de um homem ou assembléia a quem demos autoridade soberana, para fazer as regras que lhe aprouver para direção das nossas ações, e para nos castigar, quando fazemos alguma coisa contrária a elas ${ }^{448}$.

Lei, então, é a ordem daquele que desfruta da soberania, posta com o objetivo de direcionar as ações de quem a ele está submetido.

\footnotetext{
${ }^{447}$ Leviatã, p. 242.

${ }^{448}$ Leviatã, p. 438.
} 


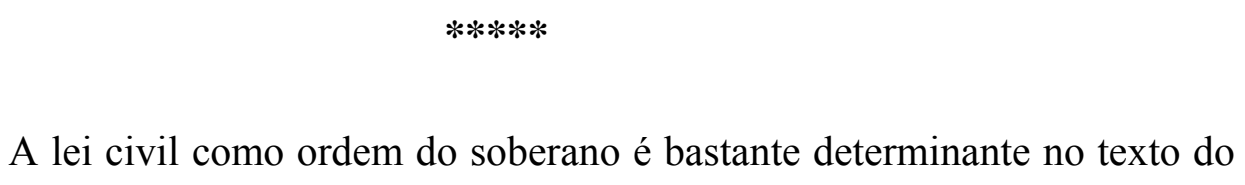

Diálogo.

O primeiro capítulo da obra, como visto, lida com o caráter racional da lei. A racionalidade é vista tanto no plano da lei de natureza como da lei humana ou civil (chamada apenas de "lei" no texto). E a principal característica da lei defendida pelo filósofo é a autoridade do soberano. A lei é lei porque colocada pelo rei da Inglaterra, e não porque usada desde os tempos mais remotos ou sugerida por juristas sábios e doutos. Hobbes é bem contundente nesse ponto: “[o] que faz uma lei não é a sabedoria, e sim a autoridade" 449 . Criticando a visão de Coke defendida pelo jurista, o filósofo afirma ainda que

suponho que ele queira dizer que a razão de um juiz ou de todos os juízes juntos, sem o rei, seja essa summa ratio e que a verdadeira lei, o que eu nego, porque fora aquele que tem o poder legislativo ninguém pode fazer uma lei. É claramente falso que a lei tenha sido depurada por homens graves e doutos, ou seja, os professores de Direito, pois todas as leis inglesas foram feitas pelos reis da Inglaterra, que consultaram a nobreza e os comuns do Parlamento, onde em vinte homens não se encontra um único jurista douto $^{450}$.

E mesmo o jurista, a quem cabe defender o direito costumeiro, concede que o poder soberano é quem determina a lei: “[c]ontudo na elaboração das leis deveria ter sido

\footnotetext{
${ }^{449}$ HOBBES, Um diálogo entre um filósofo e um jurista, p. 37.

${ }^{450}$ HOBBES, Um diálogo entre um filósofo e um jurista, p. 37.
} 
acrescentada à seriedade e à erudição dos juízes a autoridade do rei, que tem a soberania" ${ }^{451}$.

Na seqüência, Hobbes discute a finalidade da lei humana e seu poder de efetivação. Este é tirado da força militar do soberano, para que as leis não sejam meras palavras ao vento. Ambos, filósofo e jurista, comungam da mesma posição a esse respeito. O jurista: "[p]or leis entendo as leis vivas e armadas" ${ }^{452}$. O soberano deve ter armas e com elas constranger os súditos a lhe obedecer. O filósofo: "[n]esse ponto estamos de acordo, que na Inglaterra é o rei que faz as leis, seja quem for que as redija" ${ }^{453}$. A autoridade da lei pertence ao soberano, portanto, porque é ele quem tem força suficiente para garantir que ela seja cumprida à risca. Essa necessidade da lei estar sempre acompanhada da espada, embora fundamental, não aparece nos outros livros no momento em que se discute a lei civil, aparecendo apenas na discussão a respeito das atribuições da soberania. Se nas outras obras a análise da lei civil foca-se mais na sua origem e condições de validade, no Diálogo o filósofo destaca aqui uma de suas condições de eficácia.

A lei civil não precisa ter sido propriamente criada pelo rei. Basta ter sido por ele aceita ou sancionada, ou mesmo não ter sido rejeitada. "Um longo uso não dá autoridade a uma lei em virtude do tempo decorrido, mas somente em função da vontade do soberano" 454 . O jurista pergunta ao filósofo se os cânones da Igreja, o direito imperial do Almirantado, os costumes locais, os estatutos das corporações e os tribunais judiciais são lei da Inglaterra. O filósofo defende que são: “[t]odos eles foram

\footnotetext{
${ }^{451}$ HOBBES, Um diálogo entre um filósofo e um jurista, p. 38.

${ }^{452}$ HOBBES, Um diálogo entre um filósofo e um jurista, p. 43.

${ }^{453}$ HOBBES, Um diálogo entre um filósofo e um jurista, p. 43.

${ }^{454}$ Simone GOYARD-FABRE, Le droit et la loi dans la philosophie de Thomas Hobbes, p. 172.
} 
estabelecidos pelos reis da Inglaterra" $" 455$. É lei o que o rei diz ser lei: "pelo fato de ser unicamente a autoridade do rei que lhes confere vigência eles são agora leis e estatutos do rei" ${ }^{456}$.

Uma definição de lei é discutida no texto durante o momento a respeito de quem deve ocupar a judicatura suprema. O filósofo se dá conta de que eles estão discutindo há tempos questões sobre as leis, mas ainda não sabem se estão falando exatamente da mesma coisa:

Até aqui falamos das leis sem considerar nada da natureza e da essência de uma lei. E agora, a menos que definamos a palavra 'lei' só poderemos prosseguir com ambigüidade e falácia, o que seria apenas perda de tempo; ao passo que o acordo quanto às nossas palavras, ao contrário, esclarecerá tudo o que temos de dizer daqui para a frente $^{457}$.

Passam, então, a discutir o conceito de lei. Não havendo uma definição de lei presente nos estatutos, o jurista traz à análise uma definição de um jurista do século XIII, Bracton: "a lei é um estatuto justo, que ordena o que é honesto e proíbe o contrário do honesto" 458 . Essa definição é rechaçada pelo filósofo. Pois a lei não trata do honesto ou do desonesto, que são matérias relativas à honra. A lei trata, isso sim, do justo e do injusto. Mas o problema maior da definição é a possibilidade de que um estatuto seja injusto: por definição, sustenta Hobbes, não pode ser, pois o que é ou não justo é definido pelo próprio estatuto. Após refutar essa definição retirada da tradição, o filósofo propõe sua própria. Ela se dá em termos de comando do soberano: "uma lei é uma ordem daquele ou daqueles que têm o poder soberano, dada àqueles que são seus

\footnotetext{
${ }^{455}$ HOBBES, Um diálogo entre um filósofo e um jurista, p. 48.

${ }^{456}$ HOBBES, Um diálogo entre um filósofo e um jurista, p. 48.

${ }^{457}$ HOBBES, Um diálogo entre um filósofo e um jurista, p. 58.

${ }^{458}$ HOBBES, Um diálogo entre um filósofo e um jurista, p. 58.
} 
súditos, declarando publicamente e de modo claro o que todos podem fazer e o que devem se abster de fazer" ${ }^{459}$. A essa definição o jurista não opõe coisa alguma, apenas deduz que "[d]e acordo com sua definição de lei a proclamação do rei, garantida pelo Grande Selo da Inglaterra, é uma lei; pois é uma ordem, e pública, do soberano para seus súditos" ${ }^{\natural 60}$. Com o que o filósofo não discorda.

\section{Interpretações}

O tema da lei civil em Hobbes, como se pode depreender das passagens ora analisadas, não é tão controverso quanto o da lei de natureza. Enquanto a lei de natureza em Hobbes suscitou e segue suscitando incontáveis debates, longe ainda de se chegar em algum consenso, a lei civil não é objeto de tanta controvérsia.

De modo geral, ao se analisar as concepções de Hobbes a respeito da lei, o que os intérpretes mais ressaltam é, a partir de seu caráter de comando emanado pelo poder soberano, a posição de Hobbes como um precursor do positivismo jurídico. Mario Cattaneo, por exemplo, coloca Hobbes como o "pai" do positivismo inglês, seguido por Jeremy Bentham e por John Austin. A mesma posição é partilhada por M. M. Goldsmith - para ele, "Hobbes é não só um teórico do comando mas também um positivista jurídico" ${ }^{, 461}$.

\section{Conclusão}

Para saber se Hobbes partilha ou não do ideário juspositivista, necessário se faz conceituar o positivismo jurídico. A definição pode começar negativamente - o

\footnotetext{
${ }^{459}$ HOBBES, Um diálogo entre um filósofo e um jurista, p. 60.

${ }^{460}$ HOBBES, Um diálogo entre um filósofo e um jurista, p. 60.

${ }^{461}$ M. M. GOLDSMITH, Hobbes on law, p. 275.
} 
que o positivismo jurídico não defende? "O positivismo jurídico nega que princípios gerais de justiça, moralidade ou razão (como tais) são critérios para a validade da lei"462. Mais ainda: "ele [o positivismo jurídico] nega que as leis precisem ser justas, direitas, morais ou boas para serem leis" ${ }^{463}$. É uma posição claramente oposta à defendida pelos jusnaturalistas clássicos. Se o positivismo rejeita a justiça como elemento constitutivo da lei, o que ele defende? Ele defende que o direito vem da lei (escrita), encontrando sua origem e fundamento nela ${ }^{464}$. "A lei é distinguida por um teste procedimental (ou, nos termos de Ronald Dworkin, pelo pedigree): isto é, ela tem que ser significativamente percebida como o comando do legislador" ${ }^{\mathrm{4}}$.

Ora, se para o positivismo jurídico a lei é definida como comando do legislador, e Hobbes define a lei como comando do soberano (que é o legislador), tornase inescapável acomodar Hobbes entre os partidários do positivismo jurídico. De fato,

a filosofia de Hobbes propõe, numa certa análise, uma teoria das fontes do direito que afasta a doutrina tradicional do direito natural. O ordenamento jurídico não procede, na vida civil, da ordem das coisas ou do direito de natureza. O voluntarismo estatal de Hobbes está no pólo oposto do realismo aristotélico. Ele se resume nisso: o direito (no sentido jurídico do termo) é a $l e i^{466}$.

Como mencionado ao final da discussão sobre a lei de natureza enquanto ordem divina a partir do texto dos Elementos, diferentemente dos positivistas jurídicos dos séculos XIX e XX, como John Austin e Hans Kelsen, Hobbes não coloca a sanção

\footnotetext{
${ }^{462}$ M. M. GOLDSMITH, Hobbes on law, p. 275.

${ }^{463}$ M. M. GOLDSMITH, Hobbes on law, p. 275.

${ }^{464}$ Simone GOYARD-FABRE, Le droit et la loi dans la philosophie de Thomas Hobbes, p. 139.

${ }^{465}$ M. M. GOLDSMITH, Hobbes on law, p. 275.

${ }^{466}$ Simone GOYARD-FABRE, Le droit et la loi dans la philosophie de Thomas Hobbes, p. 175.
} 
como característica essencial da lei ${ }^{467}$. Certamente que a sanção é importante, mas na medida apenas em que torna o sistema jurídico efetivo (pois sem sanção as pessoas descumpririam as ordens) ${ }^{468}$.

${ }^{467}$ M. M. GOLDSMITH, Hobbes on law, p. 276.

${ }^{468}$ M. M. GOLDSMITH, Hobbes on law, p. 276. 


\subsection{Lei civil como medida das ações dos súditos}

\section{Lei civil como medida das ações dos súditos em Hobbes}

A noção de lei civil enquanto medida das ações dos súditos existe, como já visto, em consonância com a noção de comando do soberano. Ambas estão geralmente juntas, variando-se o grau de preponderância de uma em relação à outra.

Nos textos analisados, a medida das ações dos súditos é dominante apenas nos Elementos. No decorrer das demais obras, ela vai perdendo relevância, cedendo o lugar de maior destaque ao comando do soberano.

Um aspecto deveras importante para a teoria de Hobbes a respeito da lei civil como medida das ações dos súditos é que é por ela que será determinado o que é bom e o que é ruim, o que é certo e o que é errado, o que é justo e o que é injusto. "A lei civil é, em suma, a consciência do cidadão" ${ }^{\text {469 }}$. Para Hobbes, o bem e o mal não existem absolutamente em si mesmos, na natureza, pois cada um julga algo como bom ou ruim a partir do que é adequado para si, geralmente em discordância com os demais. Por isso a necessidade de um poder central para estabelecer o certo e o errado para todos. Para sobreviver, então, os homens racionalmente concordam em abrir mão de sua consciência privada em prol da consciência pública. "Isso quer dizer que no estado de natureza, onde não existe lei civil, cada particular pode julgar as ações como boas ou más, o que é impensável na república, onde a lei é a 'consciência pública",470. De forma que o problema, para Hobbes, fica em "convergir a razão privada dos indivíduos com a

\footnotetext{
${ }^{469}$ Simone GOYARD-FABRE, Le droit et la loi dans la philosophie de Thomas Hobbes, p. 136.

${ }^{470}$ Simone GOYARD-FABRE, Le droit et la loi dans la philosophie de Thomas Hobbes, p. 173.
} 
razão pública da comunidade״ ${ }^{\natural 71}$. E essa consciência pública, a razão do soberano, é a lei civil: “em uma palavra, a direção obrigatória das consciências, ao menos dos pensamentos, é, em matéria política, moral e religiosa, uma lei, é talvez a lei fundamental da república» ${ }^{472}$.

Em A discourse of laws, a obra somente recentemente atribuída a Hobbes, o filósofo inglês inicia tratando da natureza das leis. Somente depois é que as classifica segundo suas diferentes espécies e as define.

Ao apontar qual seria a verdadeira natureza das leis, Hobbes a coloca como sendo a regra para que se saiba o que é certo e errado nas situações concretas:

A natureza de todos os tipos de Leis, tanto as que dizem respeito a Deus, e Religião, e que assim têm relação com as Leis divinas, como as que dizem respeito à sociedade, e à conversação $^{473}$, e assim meramente Humanas, é propriamente esta, de ser a regra [rule] reta e perfeita, para aplicação na qual o certo [right] e o errado são discernidos, e distinguidos um do outro: e o conhecimento, e a prática delas, traz um benefício duplo, tanto Público, que é o bem comum [the general good] e o governo do Estado [State]; ou Privado, que consiste na quieta, e pacífica vida de cada um em particular ${ }^{474}$.

Contrariamente ao que Hobbes defende nas obras publicadas posteriormente, são todas as leis que deveriam atuar como medidas para as ações, para que se possa determinar se algo é certo e errado, adequado ou não ao que se deve fazer. Não somente as leis

\footnotetext{
${ }^{471}$ Marcelo Gross VILLANOVA, Lei natural e lei civil na filosofia política de Thomas Hobbes, p. 23.

${ }^{472}$ Simone GOYARD-FABRE, Le droit et la loi dans la philosophie de Thomas Hobbes, p. 137.

${ }^{473}$ Os editores esclarecem em nota que o sentido na época para o termo conversation era o do comportamento dos homens em sociedade

${ }^{474}$ A discourse of the laws, p. 105.
} 
humanas, ou civis, mas todas as demais leis - das quais Hobbes nomeia expressamente apenas as leis divinas.

Com as leis é que se pode discernir o que é certo e o que não é - pode-se concluir, portanto, que nesse ponto Hobbes não aceita que há um certo ou errado por natureza, mas apenas o que é determinado por meio de lei.

A importância dessa função da lei é percebida duplamente: não somente da perspectiva do súdito, mas também do Estado. Na perspectiva do interesse público, seguir a lei - agir de acordo com o que é considerado certo ou errado por quem coloca a lei - contribui para o bem comum. Na perspectiva do interesse privado de cada súdito, seguir a lei permite uma vida pacífica e tranqüila.

No tocante à lei como determinação do certo e do errado, como aliás nos demais pontos, a visão expressa por Hobbes em A discourse of laws ainda não é desenvolvida. Nas obras posteriores, que dão um tratamento sistemático à lei, Hobbes atribui à lei civil, e apenas a ela, o caráter de parâmetro a regular as ações dos que estão a ela submetidos.

Nos Elementos, como já afirmado, o tratamento da lei civil enquanto medida das ações dos súditos é prioritário. A lei para Hobbes não só determina o que deve ou não ser feito, mas serve de parâmetro sobre a propriedade, sobre o certo e o errado, sobre o justo e o injusto e sobre o bem e o mal ${ }^{475}$.

A lei civil é analisada por Hobbes somente na segunda parte da obra. Mesmo assim, sua definição já deixa bem estabelecido o caráter de medida das ações dos súditos:

\footnotetext{
${ }^{475}$ M. M. GOLDSMITH, Hobbes on law, pp. 274 e 275.
} 
pertence também ao julgamento do mesmo poder soberano publicar e tornar conhecida a medida comum pela qual todo homem deve saber o que é seu e o que é de outrem, o que é bom e o que é mau, o que está obrigado a fazer e o que não está, e ordenar que o mesmo seja observado. Estas medidas das ações dos súditos são aquelas que os homens chamam de leis políticas ou civis (laws politic, or civil). A elaboração destas deve, de direito, caber àquele que tem o poder da espada, pelo qual os homens são compelidos a observá-las, pois, de outra forma, elas teriam sido elaboradas em vão ${ }^{476}$.

Hobbes afirma que é por meio das leis civis que cada homem sabe o que pode ou não fazer, o que é seu ou não, o que é bom ou não. “A vontade do soberano faz a lei, criando a legitimidade ou ilegitimidade de um comportamento" ${ }^{, 477}$. Não somente ela torna os comportamentos legítimos, mas também faz deles bons ou ruins: "a concepção hobbesiana de soberania, longe de se apoiar em valores prévios de bem e de mal, de justo e de injusto, determina pelo contrário o bem e o mal, o justo e o injusto" ${ }^{\text {,78 }}$.

Importante assinalar que a lei civil atua como medida não somente das ações dos súditos - ou seja, determinando o que eles podem ou não podem fazer - mas também "deve tornar-se a base única para o entendimento moral (foro interno)" "479. É não apenas o parâmetro para a conduta humana, mas também para os valores morais da sociedade. Algo só é bom e louvável, em determinado Estado, se está de acordo com suas leis civis. Com isso cria-se, no sistema hobbesiano, duas ordens morais: há o bem

\footnotetext{
${ }^{476}$ Elementos, parte II, capítulo I, § 10, p. 69.

${ }^{477}$ Simone GOYARD-FABRE, Le droit et la loi dans la philosophie de Thomas Hobbes, p. 172.

${ }^{478}$ Simone GOYARD-FABRE, Le droit et la loi dans la philosophie de Thomas Hobbes, p. 173.

${ }^{479}$ Marcelo Gross VILLANOVA, Lei natural e lei civil na filosofia política de Thomas Hobbes, p. 20.
} 
pessoal, identificado com a satisfação do desejo que cada indivíduo sente ${ }^{480}$, e o bem público, determinado pela ordenação civil. A moral também se encontra cindida, havendo uma moral natural e uma moral civil. Hobbes defende que a moral natural seja substituída pela moral civil, mais propensa à pacificação social, de forma que "a consciência pública forjada pela lei civil constitui o parâmetro para a consciência provada" 481 .

Saber o que pode ou não fazer é, para o súdito, saber quais são seus direitos subjetivos $^{482}$. A lei civil determina não apenas a medida para as ações, mas condiciona a própria existência dos direitos civis. A liberdade correspondente ao direito, no Estado civil, é limitada e dirigida pela lei civil. Com isso, “da definição proposta por Hobbes para a lei civil, decorre a audaciosa idéia segundo a qual a lei não é somente regra, mas 'regra de direito', isto é, que ela é geradora de direito" ${ }^{483}$. Ou seja, todo o direito existente no interior da vida civil é apenas o dado pela lei civil. Ela é senhora não só da consciência e da vida moral dos súditos, mas também de suas ações: "suas decisões são geradoras do único direito jurídico que se conhece: no Estado, não há nenhum direito em desacordo com a lei"${ }^{, 484}$.

Analogamente, todas as obrigações são fruto também das disposições da lei civil: "sem as leis civis, não existiria nenhum direito no sentido jurídico do termo; portanto, não existiria nenhuma obrigação. A decisão do soberano, que se chama lei civil, cria o justo e, correlativamente, funda para todos os cidadãos seus direitos e suas obrigações" ${ }^{485}$.

\footnotetext{
${ }^{480}$ colocar referência. tem nos Elementos e no De homine.

${ }^{481}$ Marcelo Gross VILLANOVA, Lei natural e lei civil na filosofia política de Thomas Hobbes, p. 11.

${ }^{482}$ Simone GOYARD-FABRE, Le droit et la loi dans la philosophie de Thomas Hobbes, p. 174.

${ }^{483}$ Simone GOYARD-FABRE, Le droit et la loi dans la philosophie de Thomas Hobbes, p. 171.

${ }^{484}$ Simone GOYARD-FABRE, Le droit et la loi dans la philosophie de Thomas Hobbes, p. 173.

${ }^{485}$ Simone GOYARD-FABRE, Le droit et la loi dans la philosophie de Thomas Hobbes, p. 174.
} 
O caráter de estabelecimento do justo e do injusto, contudo, não é pacífico, uma vez que Hobbes, contrariamente ao que havia disposto antes, afirma numa passagem ser a lei natural a responsável pela medida do justo ${ }^{486}$.

Por fim, um dado importante é que Hobbes, no capítulo que tem a lei civil como objeto, não utiliza a noção de lei civil como medida na sua definição. Essa idéia de medida comum aparece apenas posteriormente, como necessária para dirimirem-se as controvérsias ${ }^{487}$, como se o filósofo apresentasse aqui uma segunda definição de lei civil, já incorporando a medida em seu conceito.

Em comparação aos Elementos, a lei civil enquanto medida ocupa um lugar de menos relevância em Do cidadão.

Como já apontado, antes mesmo de chegar à definição de lei civil Hobbes a coloca como a razão do soberano ${ }^{488}$. Razão, para Hobbes, pode ser compreendida também enquanto medida, enquanto relação (como no caso da razão matemática).

A definição de lei civil aparece pela primeira vez, como já visto, no momento do texto que lida com os direitos do soberano ${ }^{489}$. As leis civis são conceituadas como as regras comuns dadas pelo soberano para todos, "de modo que todo indivíduo possa saber o que pode ser chamado seu ou de outrem, o que justo, o que injusto, honesto, desonesto, bom, mau, isto é, em resumo, o que deve ser feito e o que deve ser evitado no curso da nossa vida em comum"490. A mesma idéia segue no

\footnotetext{
${ }^{486}$ Elementos, parte II, capítulo VI, § 10, p. 69.

${ }^{487}$ Elementos, parte II, capítulo X, § 8 p. 69.

${ }^{488}$ Do cidadão, capítulo II, nota 3, p. 69.

${ }^{489}$ Do cidadão, capítulo VI.

${ }^{490}$ Do cidadão, p. 106.
} 
resumo feito por Hobbes pouco depois: " $[\mathrm{e}]$ as leis civis assim as definimos: nada mais são do que as ordens de quem tem autoridade principal na cidade, dirigindo as ações futuras dos cidadãos"491. Leis civis, portanto, não podem prescindir do caráter de direção das ações dos súditos.

Após esse momento, Hobbes permanece certo tempo afastado das questões sobre lei. O tema somente retorna ao texto nas discussões a respeito das causas de dissolução do governo ${ }^{492}$.

Mas também mostramos que num Estado civil as leis constituíam as regras do bem e do mal, do que é justo e injusto, honesto ou desonesto; e que, portanto, o que o legislador ordene deve ser considerado bom, e mau o que ele proíbe; e o legislador sempre é aquela pessoa que detém o poder supremo na república, isto é, numa monarquia o monarca ${ }^{493}$.

Aqui, a lei civil é definida precisamente em termos de medida do certo e do errado.

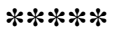

Assim como em Do cidadão, a lei civil é analisada no Leviatã primeiramente no capítulo dos direitos do soberano ${ }^{494}$. Mas, diferentemente do texto presente em Do cidadão, no Leviatã ela é definida não como comando do soberano, mas sim como medida:

Essas regras da propriedade (ou o meum e o tuum), tal como o bom e o mau, ou o lícito e o ilícito nas ações dos súditos, são as leis civis, ou seja, as leis

\footnotetext{
${ }^{491}$ Do cidadão, p. 106.

492 Do cidadão, capítulo XII.

${ }^{493}$ Do cidadão, p. 182.

${ }^{494}$ Leviatã, capítulo XVIII.
} 
de cada república específica, embora hoje o nome de direito civil se aplique apenas às antigas leis civis da cidade de Roma, pois, sendo esta a capital de uma grande parte do mundo, suas leis eram nesse tempo o direito civil dessa região ${ }^{495}$.

Posteriormente, a lei civil é dada novamente como medida, ao confirmarse o que se tratou a respeito de domínio (tanto paterno como despótico): “[p]ertence portanto ao soberano ser juiz, e prescrever as regras para distinguir entre o bem e o mal, regras estas que são as leis; por conseqüência, é nele que reside o poder legislativo"496. Algumas vezes, como nesta passagem, Hobbes usa o termo lei para referir-se especificamente à lei civil.

Mais uma vez antes de lidar com a lei civil enquanto objeto principal de investigação, Hobbes a postula enquanto medida, ao defender que os poderes dos representantes dos soberanos são limitados por cartas e por leis:

E como essa limitação nem sempre é fácil, ou talvez possível de ser descrita numa carta, é preciso que as leis ordinárias, comuns a todos os súditos, determinem o que é legítimo aos representantes fazer, em todos os casos sobre os quais as cartas se omitam $^{497}$.

Ao tomar lei civil como tema de análise, Hobbes começa tratando-a mais em termos de comando. Contudo, após algumas considerações, traz uma definição mais completa, a qual agrega a noção de medida:

Considerando isto, defino a lei civil da seguinte maneira: A LEI CIVIL é para todo súdito

\footnotetext{
${ }^{495}$ Leviatã, p. 153.

${ }^{496}$ Leviatã, p. 176.

${ }^{497}$ Leviatã, p. 192.
} 
constituída por aquelas regras que a república lhe impõe, oralmente ou por escrito, ou por outro sinal suficiente da sua vontade, para usar como critério de distinção entre o bem e o mal, isto é, do que é contrário à regra ${ }^{498}$.

Na explicação que dá a respeito da definição, Hobbes pontua fortemente o caráter de medida que a lei civil deve possuir: “[e] também que as leis são as regras do justo e do injusto, não havendo nada que seja considerado injusto e que não seja contrário a alguma lei"499.

Após isso, ocorrem algumas passagens isoladas em que Hobbes determina a lei civil como medida. Elas são apresentadas a seguir.

Ao tratar da dissolução da república, há a seguinte passagem: “[i]sso é verdade na condição de simples natureza, quando não existem leis civis, e também sob o governo civil nos casos que não estão determinados pela Lei. Mas não sendo assim é evidente que a medida das boas e das más ações é a lei civil" ${ }^{100}$, demonstrando que o caráter de medida das ações não pode afastar-se da lei civil.

Diversas considerações sobre lei são realizadas no grande capítulo em que o filósofo analisa o poder eclesiástico. Em uma dessas considerações, Hobbes aponta as leis civis como medidas das ações dos súditos:

E os criadores das leis civis não são apenas os declarantes, são também os criadores da justiça e injustiça das ações, pois nada há nos costumes dos homens que os faça íntegros e iníquos, a não ser a sua conformidade com a lei do soberano. Portanto, quando o papa reclama a supremacia quanto às

\footnotetext{
${ }^{498}$ Leviatã, p. 226.

${ }^{499}$ Leviatã, p. 226.

${ }^{500}$ Leviatã, p. 273.
} 
controvérsias de costumes, está ensinando os homens a desobedecer ao soberano civil, o que é uma doutrina errônea, contrária aos muitos preceitos do nosso Salvador $^{501}$.

Por fim, na quarta e última parte do livro, ao combater as doutrinas dos gregos e dos romanos, Hobbes trata mais uma vez a lei civil como medida:

[a] sua filosofia moral [dos gregos] não passa de uma descrição das suas próprias paixões. De fato, a regra dos costumes sem o governo civil é a lei de natureza, e nela a lei civil, que determina o que é honesto e desonesto, o que é justo e injusto, e geralmente o que é bom e $m a u^{502}$.

Trata-se da última vez em que Hobbes usa a lei civil no sentido de medida.

Registre-se, ainda, que a noção de lei civil como medida não é utilizada nenhuma vez no Diálogo.

Foi somente no último texto publicado por Hobbes que a lei civil tomada enquanto medida das ações recebeu sua análise mais desenvolvida. Trata-se do De homine. O De homine constitui a segunda parte do sistema geral de filosofia de Hobbes, formado ainda pelo De corpore (a primeira parte) e pelo De cive ou Do cidadão (a última parte). O De homine, não obstante ser a segunda parte, foi publicado em último lugar, tardiamente, apenas em 1669. Justificando a demora da publicação, Hobbes

\footnotetext{
${ }^{501}$ Leviatã, p. 469.

${ }^{502}$ Leviatã, p. 557.
} 
explica na dedicatória que esteve "combatendo as bestas-feras [I've been fighting the beasts] ${ }^{, 503}$.

De modo geral, a obra trata de temas já explorados tanto na primeira parte dos Elementos como na primeira parte do Leviatã. Não há muita novidade aqui, o que explica a obscuridade que a obra ainda desfruta entre os estudiosos do pensamento de Hobbes ${ }^{504}$.

No final do capítulo XIII da obra, que trata de "disposições e condutas", Hobbes aprofunda a noção de um parâmetro a guiar as condutas humanas:

9. Portanto um parâmetro comum [a common standard] para as virtudes e os vícios não aparece antes da vida civil; este parâmetro não pode, por esta razão, ser outro além das leis de cara Estado [state]; pois a lei natural, quando esse Estado é constituído, torna-se parte da lei civil ${ }^{505}$.

É exatamente a mesma idéia já presente nos demais textos - a de que a lei civil serve como medida do que é bom ou não que se faça em sociedade. Além disso, Hobbes adianta o argumento, desenvolvido em Do cidadão, de que a lei civil é não mais que a lei de natureza posta pelo Estado.

Hobbes, de forma mais detida que nos outros textos, trata na seqüência de uma possível objeção:

Nem há impedimento algum para tal tese o fato de que leis são inumeráveis e que já houve Estados com diferentes leis. Pois, quaisquer que sejam as leis, não as violar é sempre e em qualquer lugar tomado como sendo a virtude

\footnotetext{
${ }^{503}$ De homine, p. 42.

${ }^{504}$ Tanto que até hoje não há nenhuma tradução, nem mesmo para o inglês, da obra completa. Foram traduzidos apenas os últimos capítulos. Os nove primeiros, que tratam de biologia e ótica, só estão disponíveis em latim. Cf. Bernard Gert, Editor's note, p. 35.

${ }^{505}$ De homine, XIII, § 9, p. 69.
} 
dos cidadãos, e negligenciá-las e tomado como um vício $^{506}$.

Há, aqui, a idéia de que o que ele entende por lei não é cada lei específica de cada país, mas sim a lei tomada como um conceito ${ }^{507}$. É o que o filósofo já havia deixado claro no Leviata $\tilde{a}^{508}$. De modo que, para qualquer Estado, qualquer que seja a lei que ele edite será a regra a determinar quais as condutas adequadas a serem seguidas. E por isso o que é justo numa situação pode ser injusto em outra (a depender de qual lei civil que regule a situação concreta) - mas a justiça consiste sempre em respeitar a lei, qualquer que seja ela:

Apesar de ser verdade que certas ações podem ser justas em um Estado, e injustas em outro, apesar disso a justiça (isto é, não violar as leis) é e tem que ser em todo lugar a mesma. Além disso, aquela virtude moral, aquela que nós efetivamente medir pelas leis civis, que é diferente nos diferentes Estados, é a justiça e a eqüidade ${ }^{509}$.

São, assim, as leis civis os critérios para se definir a justiça. Não somente a justiça, mas também as boas ações - ou seja, a moral:

Então, condensando todo esse ensinamento sobre a conduta [manner] e disposições em poucas palavras, eu digo que boas disposições são aquelas que são adequadas para se entrar na sociedade civil [civil society]; e boas maneiras [manners] (isto é, as virtudes morais) são aquelas pelas quais os que as seguem podem ser melhor preservados. Pois todas as virtudes estão contidas na justiça e na caridade. Por isso pode-se também entender

\footnotetext{
${ }^{506}$ De homine, XIII, § 9, p. 69.

${ }^{507}$ Simone GOYARD-FABRE, Le droit et la loi dans la philosophie de Thomas Hobbes, p. 168.

${ }^{508}$ Ao dizer que "[e]ntendo por LEIS CIVIS aquelas leis que os homens são obrigados a respeitar, não por serem membros desta ou daquela república em particular, mas por serem membros de uma república". Leviatã, p. 225.

${ }^{509}$ De homine, XIII, § 9, p. 69.
} 
que disposições contrárias a essas são perniciosas; e que as condutas contrárias e os vícios estão todos conditos na injustiça e numa mente inacessível às maldades dos outros, isto é, uma falta de caridade ${ }^{510}$

Com o que a moral, no sistema hobbesiano, fica, após a instituição do Estado civil, inteiramente submetida ao que o soberano determina por meio de suas leis civis. A partir do que estas determinam, o súdito sabe não somente qual ação é justa e adequada, mas também qual é virtuosa e conforme às virtudes morais.

A submissão da moral aos conteúdos das leis civis é necessária em função da determinação da paz no interior do Estado. Caso cada súdito possa pensar com sua própria cabeça, pensa Hobbes, as discórdias inevitavelmente irão aparecer.

A preservação do juízo particular na esfera do Estado é perturbadora ou enfraquecedora do seu poder, isto é, da segurança e harmonia da comunidade. O é, porém, apenas na medida em que sua consciência ou juízo é alheio ao parâmetro do estabelecido pelo poder soberano ${ }^{511}$.

Sendo assim, o ideal é que haja uma coincidência entre o juízo privado do cidadão e a disposição da vontade pública por meio da lei civil ${ }^{512}$. Se não houver, quem deve prevalecer, para o bem dos próprios súditos, é a lei civil.

\footnotetext{
${ }^{510}$ De homine, XIII, $\S 9$, pp. 69 e 70.

${ }^{511}$ Marcelo Gross VILLANOVA, Lei natural e lei civil na filosofia política de Thomas Hobbes, p. 37.

512 "Parece manifesto que a lei civil não deve ser vista como mero parâmetro para o fórum externo. (...) Há a pretensão de que os termos da lei positiva convirjam com os termos do parâmetro do fórum interno dos indivíduos (no que tange à intenção das ações) com vistas a evitar algumas causas das enfermidades ou doenças de um Estado". Marcelo Gross VILLANOVA, Lei natural e lei civil na filosofia política de Thomas Hobbes, p. 40.
} 


\section{Relações entre lei de natureza e lei civil}

A respeito das teorias sobre a lei de natureza, pode ser feita inicialmente uma primeira divisão, entre autores que não aceitam a existência de um direito natural (entre eles temos Trasímaco e Carnéades, por exemplo) e os que aceitam. No caso dos que não a aceitam, existe apenas a lei humana, a lei colocada pelo homem e aceita por convenção. Entre os autores que aceitam a existência de uma lei de natureza, sempre se fez importante precisar qual seria a relação entre essa lei e a lei humana. A relação entre as duas pode ser, num primeiro plano, de identidade ou de diferença. Dessa forma, pode-se conceber que a lei de natureza seja a mesma coisa que a lei civil, ou que não seja. Não sendo exatamente a mesma coisa, pode ser que esteja uma contida na outra ou haver qualquer outro tipo de intersecção entre ambas. Se forem diferentes, o que caracteriza o pensamento dos filósofos chamados jusnaturalistas é que a lei natural possui precedência sobre a lei humana - em caso de discordância entre ambas, a que deve prevalecer é a lei de natureza. Tem-se, assim, a "teoria do direito natural, conforme sustentam e defendem os jusnaturalistas, ou seja, um direito fundamentado na natureza em contraposição ao direito baseado na autoridade" ${ }^{, 513}$. Precisamente por isso pode-se dizer que "para classificar uma teoria como jusnaturalista, há dois quesitos: 1) admissão do direito natural como direito; 2) afirmação do direito natural como superior ao direito positivo" ${ }^{, 514}$. Não há caso conhecido de autor que aceite a existência da lei de natureza mas que a coloque abaixo da lei humana ${ }^{515}$.

Essa relação, entre a lei dada pela natureza e a lei posta pelos homens, espelha um conflito primordial, central no pensamento grego, entre duas ordens de realidade: entre a ordem da natureza (da phisis) e a ordem da convenção humana (do

\footnotetext{
${ }^{513}$ Norberto BOBBIO, Locke e o direito natural, p. 26.

${ }^{514}$ Norberto BOBBIO, Locke e o direito natural, p. 45.

${ }^{515}$ Norberto BOBBIO, Locke e o direito natural, p. 45.
} 
nomos). Com as mudanças na mentalidade grega ocorridas a partir do século V a.C., "ao costume tradicional - ao nomos de Atenas, a seu direito - eis que agora, numa crise de confiança, opõe-se a justiça (diké) ou então a natureza e sua ordem (phisis)" ${ }^{, 516}$. A ordem da natureza era definida por oposição à ordem da criação humana: por natureza entendia-se "todas as coisas que não são produzidas pelo homem" central que não esteve restrito às obras dos filósofos, mas pode ser encontrado de maneira determinante também entre os dramaturgos e os historiadores.

No caso específico do direito, o problema consistia em determinar se ele seria natureza ou arte humana. A resposta, para os gregos, era via de regra ambivalente: "[d]ireito é natureza e direito também é arte",518, o que gerou a "dicotomia entre direito natural versus direito positivo" $" 519$.

Essa oposição entre lei humana e lei eterna aparece já na Antígona. Em linhas gerais, a peça trata do esforço da protagonista, Antígona, para enterrar seu irmão. É a partir disso que o conflito é instaurado: pela lei divina, Polinices, o irmão, deveria ser enterrado. Entretanto, pela lei humana, deveria ser abandonado ao relento, para servir de alimento aos abutres e cães, como advertência aos que ousarem contrariar o poder do rei.

Desde o princípio Antígona vai contra a lei dos homens, temendo profanar a vontade dos deuses. Sua posição é manifesta desde o começo: "ISMÊNIA Você tem a audácia de enfrentar o edital de Creonte e a ira do povo? ANTÍGONA -

\footnotetext{
${ }^{516}$ Michel VILLEY, A formação do pensamento jurídico moderno, p. 18.

${ }^{517}$ Norberto BOBBIO, Locke e o direito natural, p. 28.

${ }^{518}$ Norberto BOBBIO, Locke e o direito natural, p. 30.

${ }^{519}$ Norberto BOBBIO, Locke e o direito natural, p. 30.
} 
Nenhum dos dois é mais forte do que o respeito a um costume sagrado" ${ }^{\text {"520 }}$. A disputa se dá entre a lei dos deuses, por um lado, e a lei dos homens, por outro.

A lei humana tem bastante realce na peça. É o rei, Creonte, quem "administra o poder e executa as leis" ${ }^{521}$. Para cuidar da ordem e da paz na cidade o rei, nas palavras de Corifeu, possui "o direito e o poder de determinar qualquer ação",522.

Mas Antígona não aceita que a lei humana esteja acima da lei dos deuses. São estas, as leis eternas, as que Antígona defende. Dirigindo-se a Creonte:

A tua lei não é a lei dos deuses; apenas o capricho ocasional de um homem. Não acredito que tua proclamação tenha tal força que possa substituir as leis não escritas dos costumes e os estatutos infalíveis dos deuses. Porque essas não são leis de hoje, nem de ontem, mas de todos os tempos; ninguém sabe quando apareceram. $^{523}$

No final da peça, com a tragédia já consumada, o rei Creonte percebe o quanto a lei humana é frágil frente à lei eterna, terminando por compreender "a destruição que causei por não reconhecer que havia leis antes de mim",524.

A idéia de que a ordem humana opunha-se à ordem natural manifestou-se em ocasiões diferentes na Grécia antiga, entre elas na História da Guerra do Peloponeso, obra de Tucídides que viria a ser traduzida por Hobbes.

A mesma posição crítica em relação à ordem social tradicional, com apelo à natureza, exprime-se em diversos outros textos da mesma época: assim, em Tucídides, no

\footnotetext{
${ }^{520}$ SÓFOCLES, Antígona, p. 8.

${ }^{521}$ SÓFOCLES, Antígona, p. 13.

${ }^{522}$ SÓFOCLES, Antígona, p. 14.

${ }^{523}$ SÓFOCLES, Antígona, p. 25.

${ }^{524}$ SÓFOCLES, Antígona, p. 60.
} 
famoso discurso aos mélios em que os atenienses justificam uma agressão contrária ao direito invocando a lei de natureza ${ }^{525}$.

$\mathrm{Na}$ filosofia, a relação entre a ordem da natureza e a ordem humana se fez presente desde o início. No jusnaturalismo cosmológico dos pré-socráticos, a lei humana tem seu fundamento a partir da lei de natureza. A partir do logos de Heráclito, ela é a fonte da qual as leis dos homens se alimentam ${ }^{526}$.

Uma defesa importante da lei de natureza contra as leis da polis foi feita pelos sofistas: “interessante (...) é a reação de alguns sofistas que parecem ter feito apelo, conforme os diálogos de Platão, à lei de natureza (phisis), contra a lei da polis" ${ }^{\text {227 }}$. Como conseqüência, “a contraposição entre natureza e convenção teve, na maioria dos sofistas, efeitos revolucionários, pois tornou possível a crítica das instituições positivas, meramente 'convencionalistas', à luz do natural"528 .

Contra os sofistas insurgiu-se Sócrates. "Em Memoráveis (IV, 4s.), Xenofonte faz a justiça e as leis serem defendidas por Sócrates contra os sofistas; aliás, Sócrates refere-se aqui, mais que às leis positivas escritas, às leis 'não-escritas' que, por exemplo, proíbem o incesto" ${ }^{\text {529 }}$. A mesma posição é expressa por Platão, de acordo com Villey: "[t]ambém se lê no tratado das Leis, numa expressão que será retomada inúmeras vezes, que uma lei injusta, uma lei ruim não é uma lei, não é direito" ${ }^{\text {,50 }}$.

\footnotetext{
${ }^{525}$ Michel VILLEY, Formação do pensamento jurídico moderno, p. 19. Referindo-se a Tucídides, La guerre du Péloponnèse, trad. Fr. J. de Romilly, Paris, Belles Letres, 1962, v. 85.

${ }^{526}$ Cf. A. Truyol SERRA, História da filosofia do direito e do Estado, p. 89.

${ }^{527}$ Michel VILLEY, Formação do pensamento jurídico moderno, p. 19.

${ }^{528}$ A. Truyol SERRA, História da filosofia do direito e do Estado, p. 97.

${ }^{529}$ Michel VILLEY, Formação do pensamento jurídico moderno, p. 20.

${ }^{530}$ Michel VILLEY, Formação do pensamento jurídico moderno, p. 25.
} 
Em Aristóteles a oposição também está presente. A concepção aristotélica de direito natural é formulada em oposição à de direito não-natural ${ }^{531}$ : “[e]m vários pontos, Aristóteles fala da distinção entre direito natural e direito positivo" ${ }^{\text {5 }}$. Além da justiça natural existe, portanto, uma outra justiça, não natural e convencional, a ser aplicada aos casos que não são universais e nem necessários. "Essas normas particulares, em vigor num contexto específico, constituem uma convenção e circunscrevem o direito convencional" ${ }^{\text {533 }}$. Aristóteles a chama de justiça legal. O conteúdo de suas normas pode variar em muito, mas não pode nunca se dar em oposição ao que determina o direito natural.

Nas palavras do Estagirita,

da justiça política, uma parte é natural, a outra é legal. A natural tem em qualquer lugar a mesma eficácia, e não depende das nossas opiniões; a legal é, em sua origem, indiferente que se faça assim ou de outro modo; mas, uma vez estabelecida, deixa de ser indiferente ${ }^{534}$.

Há, assim, dois direitos observados no mundo. Segundo Norberto Bobbio,

[o] interesse dessa distinção aristotélica consiste no fato de que ela busca o critério de delimitação com respeito à respectiva matéria do direito natural e do direito positivo: a matéria do direito natural corresponde aos comportamentos que são bons ou maus em si mesmos; a

\footnotetext{
${ }^{531} \mathrm{Na}$ Grécia antiga não era evidente a distinção entre o direito e o justo. O idioma grego possui apenas uma palavra (díkaion) para indicar os dois conceitos. O justo natural equivalia ao direito natural, e o justo convencional ou legal ao direito positivo. Cf. Michel VILLEY, Formação do pensamento jurídico , moderno, p. 26.

${ }^{532}$ Norberto BOBBIO, Locke e o direito natural, p. 33.

${ }^{533}$ Alberto Alonso MUÑOZ, O paradigma aristotélico, p. 142.

${ }^{534}$ ARISTÓTELES, Ética a Nicômacos, Brasília, Editora Universidade de Brasília, 2. ${ }^{\text {a }}$ edição, 1992, p. 102. Citado por Norberto BOBBIO, Locke e o direito natural, p. 33.
} 
matéria do direito positivo começa onde cessa a do direito natural e concerne às ações indiferentes ${ }^{535}$.

Já que há dois tipos de direito, a pergunta que segue é: qual dos dois deve prevalecer? De acordo com Aristóteles, em caso de conflito entre o que determina o direito natural e o que determina o direito positivo, é o primeiro que deve ser aplicado:

Se a lei escrita é contrária à nossa causa, torna-se necessário utilizar a lei comum e a eqüidade, que é mais justa (...). Com efeito, a eqüidade sempre dura, e não está destinada a mudar; e até mesmo a lei comum (pelo fato de ser natural) não muda, enquanto as leis escritas mudam com freqüência ${ }^{536}$.

Como um aglutinador das posições anteriores a respeito da lei de natureza, Cícero também tratou da relação dela com a lei dos homens. Jusnaturalista convicto, o jurista romano defendia que em caso de desacordo quem deveria preponderar seria a lei natural. Essa lei, correspondente à reta razão e promulgada por Deus, "não pode ser contestada, nem derrogada em parte, nem anulada",537. Não pode, em suma, ser contrariada, em hipótese alguma, pela lei civil. Contra as concepções convencionalistas, Cícero é enérgico na defesa de um direito justo por natureza. As leis dos tiranos não são justas apenas por serem leis: "mas, o maior absurdo é supor-se que são justas todas as instituições e leis dos povos" ${ }^{\text {538 }}$. Elas são justas apenas se de acordo com a natureza. Portanto, "existe um só Direito, aquele que constitui o vínculo da sociedade humana e que nasce de uma só Lei; e esta Lei é acertada em tudo quanto ordena e proíbe. Quem a ignora é injusto, esteja ela escrita ou não em alguma parte"539. De modo que não é a lei humana a verdadeira guia para a ação justa. "Se a justiça

\footnotetext{
${ }^{535}$ Norberto BOBBIO, Locke e o direito natural, p. 34.

${ }^{536}$ ARISTÓTELES, Retórica, 1375a. In: Norberto BOBBIO, Locke e o direito natural, p. 35.

${ }^{537}$ CÍCERO, Da república, Livro III, § XVII.

${ }^{538}$ CÍCERO, Das leis, Livro I, § 41, p. 49.

${ }^{539}$ CÍCERO, Das leis, Livro I, § 42, p. 49.
} 
consiste na obediência às leis escritas e na conformação às instituições dos povos e (...) se tudo deve ser medido pela regra da utilidade, então, qualquer um (...) tratará (...) de desobedecer e violar as leis" ${ }^{340}$. Cícero combate a noção de que a justiça e o direito vêm das leis humanas - para ele, vêm da natureza. "Em conseqüência, a justiça simplesmente não existe se não deriva da natureza e a utilidade acaba com toda justiça construída com base na utilidade; se a natureza não confirmar o direito, todas as virtudes ruem"541. A virtude não é convencional - ela é natural: "[a] virtude é uma razão perfeita; não há dúvida que sua base é natural"542. Do mesmo modo, "se o bem é louvável é porque encerra em si mesmo algo que nos obriga a louvá-lo; pois o bem não depende das convenções e sim da Natureza"543. É bastante claro que, para Cícero, a verdadeira lei não é humana, mas sim natural: “[n]a opinião dos mais eminentes sábios, a lei não é o produto da inteligência humana, nem da vontade popular, mas algo eterno que rege o universo por meio de sábios mandatos e sábias proibições" ${ }^{\text {"54 }}$. As leis humanas podem ser chamadas de leis apenas impropriamente, por derivação da verdadeira lei que é a lei da natureza: "[q]uanto às leis, que em formas e oportunidades diversas se impuseram os povos, tomam este título mais por concessão do que por natureza" 545 . A lei humana aparece sempre submetida à natureza. "A lei é uma diferença entre o justo e o injusto, feita de acordo com a Natureza, ou melhor, com a mais antiga e essencial de todas as coisas; e à Natureza sujeitam-se as leis humanas, que ameaçam os maus com os castigos, enquanto defendem e protegem os bons" ${ }^{\text {"546. }}$.

\footnotetext{
${ }^{540}$ CÍCERO, Das leis, Livro I, § 42, pp. 49 e 50.

${ }^{541}$ CÍCERO, Das leis, Livro I, $\S \S 42$ e 43, p. 50.

${ }^{542}$ CÍCERO, Das leis, Livro I, $\S 45$, p. 50.

${ }^{543}$ CÍCERO, Das leis, Livro I, § 46, p. 51.

${ }^{544}$ CÍCERO, Das leis, Livro II, p. 63.

${ }^{545}$ CÍCERO, Das leis, Livro II, p. 65.

${ }^{546}$ CÍCERO, Das leis, Livro II, p. 66.
} 
A partir do cristianismo, a lei de natureza passa a ser identificada preponderantemente com a lei divina presente nos textos sagrados. Com efeito, no Decretum gratiniani: de jure naturae et constitutionis, consta que "pela sua virtude o direito natural prevalece sobre o costume e a constituição. Se contrário ao direito natural, tudo o que for admitido pelo costume ou pelas leis deve ser considerado falso ou nulo",547. A respeito do eventual conflito entre a lei de natureza e a lei positiva, Tomás de Aquino defende a mesma posição de Aristóteles: “[q]ualquer lei estabelecida pelos homens é autêntica na medida em que deriva da lei da natureza; se discordar desta, já não será uma lei, mas corrupção de lei" ${ }^{, 548}$. É a supremacia do direito de natureza frente ao direito dos homens ${ }^{549}$.

\section{Relações entre lei de natureza e lei civil em Hobbes}

Analisadas as concepções de lei natural e de lei civil em Hobbes, é hora de ver quais as relações tecidas pelo filósofo entre ambas.

Hobbes traça tanto relações de identidade quanto de diferença entre lei natural e lei civil. Em certos aspectos elas diferem fortemente ${ }^{550}$, ao passo que em outros são praticamente a mesma coisa. Pode-se dizer que em certos casos - como no fato da lei natural atuar em foro interno e a lei civil em foro externo - há uma relação de

\footnotetext{
${ }^{547}$ Citado por Norberto BOBBIO, Locke e o direito natural, p. 37.

${ }^{548}$ Suma teológica, questão 25, artigo 2. In: Norberto BOBBIO, Locke e o direito natural, p. 40.

${ }^{549}$ É a visão tomista a da Igreja Católica hoje. Quando do episódio do aborto da menina de nove anos estuprada pelo padrasto em Pernambuco em março de 2009, a justificativa para a excomunhão foi o argumento de Tomás: "Acreditar em Deus significa aceitar que Deus é a origem de tudo e é também o nosso fim. Essa é uma verdade fundamental. É premissa importantíssima para dizer que a lei de Deus está acima de qualquer lei humana. E a lei de Deus não permite o aborto. Então, se uma lei humana está contradizendo a lei de Deus, no caso, a que permitiu a operação, essa lei não tem nenhum valor.” Trecho da entrevista do arcebispo de Olinda e Recife, Dom José Cardoso Sobrinho, à Revista Veja, edição 2104, ano 42, n. ${ }^{\text {a } 11, ~ d e ~} 18$ de março de 2009, p. 19.

550 "Não há dúvida que Hobbes considera os termos 'lei natural' e 'lei civil' como termos que significam coisas diferentes. E, por essa razão, suas definições são contrastantes". Marcelo Gross VILLANOVA, Lei natural e lei civil na filosofia política de Thomas Hobbes, pp. 38 e 39.
} 
exclusão total; mas em outras situações - como no fato de que ambas se contêm uma à outra e são de mesma extensão - a relação observada é de inclusão total ${ }^{551}$. O problema é que, a princípio, dois ordenamentos não podem ter entre si relações de exclusão e de inclusão concomitantemente. Sem dúvida o estabelecimento da relação precisa que há entre lei natural e lei civil torna-se uma questão delicada.

Nos diferentes textos, as análises de Hobbes também se aproximam. Com exceção dos Elementos, Hobbes aponta e desenvolve as conseqüências problemáticas de se relacionar os dois conceitos.

As relações entre lei natural e lei civil estabelecidas por Hobbes, nos Elementos, são bastante sutis. Ele não chega a tocar nos pontos problemáticos, como ocorre nas demais obras. Contudo, há passagens de interesse.

Nos Elementos, logo ao início do livro, Hobbes coloca lei natural e lei civil (chamada por ele, aqui, de lei política, como no título da obra) numa mesma unidade conceitual: “[a] verdadeira e claríssima explicação dos elementos das leis natural e política (que é o meu objetivo presente) depende do conhecimento do que é a natureza humana, do que é um corpo político e do que é isso a que chamamos uma lei" ${ }^{552}$. Ou seja: ambos os conceitos são passíveis de compreensão conjunta ao se estabelecer propriamente o que é a natureza humana, o que é um corpo político e o que é uma lei. Há, dessa forma, por trás das diferenças, um mesmo plano de fundo entre as duas idéias.

\footnotetext{
${ }^{551}$ Marcelo Gross VILLANOVA, Lei natural e lei civil na filosofia política de Thomas Hobbes, p. 19.

${ }^{552}$ Elementos, p. 19.
} 
Nas considerações gerais a respeito da lei de natureza, Hobbes determina que uma lei fundada não na razão, com o que se identificaria com a lei de natureza, mas sim nos costumes, iria contra a própria lei de natureza:

Entre as leis de natureza, não se enumeram costumes ou prescrições. Pois qualquer ação que seja contra a razão, por mais que ela seja reiterada ou que haja precedentes para ela, será sempre contra a razão e, portanto, não será uma lei de natureza, mas uma lei contrária a ela ${ }^{553}$.

Um ponto importante é que, mesmo Hobbes não dizendo expressamente, lei natural e lei civil têm campos distintos de atuação em alguns momentos. Por exemplo, a lei civil não pode regular a consciência, que é matéria da lei natural:

Para abandonar esse escrúpulo de consciência acerca da obediência às leis humanas, entre aqueles que interpretam por si mesmos a palavra de Deus nas Sagradas Escrituras, proponho para a sua consideração, primeiro, que nenhuma lei humana intente obrigar a consciência de um homem, exceto a impedi-lo em sua ação, seja com a língua, seja com outra parte do corpo ${ }^{554}$.

Não é por uma razão ontológica ou lógica que a lei civil não pode regular a consciência, mas prática: "[a] lei feita para aquilo [obrigar a consciência] seria sem efeito, porque nenhum homem é capaz de discernir, senão pela palavra ou outra ação qualquer, a lei a ser mantida ou quebrada" ${ }^{, 555}$. Uma lei com vistas a obrigar a consciência mostra-se ineficaz, eis que impossível determinar se a lei está sendo cumprida ou não.

\footnotetext{
${ }^{553}$ Elementos, capítulo XVII, § 11 p. 69.

${ }^{554}$ Elementos, Parte II, capítulo VI, § 3, p. 69.

${ }^{555}$ Elementos, Parte II, capítulo VI, § 3, p. 69
} 
Ao falar dos deveres de quem detém o poder soberano, Hobbes deixa claro que suas ações (e dentre elas a promulgação de leis civis) não podem contrariar as leis de natureza. Afirma que o soberano pode fazer tudo (nada do que faça é injúria ao súdito), mas que "quando eles [os atos do soberano] tendem ao sofrimento do povo em geral eles são violações da lei de natureza, e da lei divina" ${ }^{\text {556 }}$. As leis civis não podem contradizer as leis de natureza: não podem prescrever ingratidão, arrogância, iniqüidade etc. Pois tal determinação acabaria gerando guerra e ausência de paz e segurança. Por isso é que "todas as leis civis estão a serviço dos cidadãos, da segurança de suas vidas, do conforto de sua condição",557.

Que a lei civil não pode mesmo contrariar a lei natural fica bem claro no último capítulo, que trata das leis civis. Nele, Hobbes, ao distinguir lei de direito, esclarece que todas as ações são feitas por direito civil, direito natural ou direito divino. A partir disso conclui que "a lei civil não pode fazer com que seja jure aquilo que é contra a lei divina, ou de natureza" ${ }^{, 558}$. Sendo assim, o que não é feito contra a lei civil (pelo súdito) ou contra a lei de natureza (pelo soberano) é considerado de acordo com o direito divino. Nesse ponto da argumentação, Hobbes aproxima sempre a lei de natureza da lei divina:

Mas dizer lege divina, por lei divina, é uma outra coisa. Pois as leis de Deus e da natureza permitem uma liberdade maior do que aquela que é permitida pela lei civil, pois as leis subordinadas ainda obrigam mais do que as leis superiores, a essência da lei sendo não livrar, mas sim atar, pode um homem ser comandado a algo pela lei civil, ao que

\footnotetext{
${ }^{556}$ Elementos, Parte II, capítulo IX, $\S 1$, p. 69.

${ }^{557}$ Simone GOYARD-FABRE, Le droit et la loi dans la philosophie de Thomas Hobbes, p. 177.

${ }^{558}$ Elementos, Parte II, capítulo X, $\S 5$, p. 69.
} 
não seria comandado pela lei de natureza, nem pela lei divina ${ }^{559}$.

A lei civil, em relação à lei natural, especifica comportamentos. Seu único limite é não ir contra o disposto pela lei natural (tomada em conjunto com a lei divina). Do mesmo modo, na seqüência do texto Hobbes compara a lei civil com a lei divina, determinando que nem tudo que é obrigatório para a lei divina, como a esmola e a caridade, é obrigatório para a lei civil.

A relação que Hobbes estabelece entre lei natural e lei civil fica bastante evidente na classificação que o filósofo dá dos diferentes tipos de leis. Segundo ele, há três critérios para diferenciar as leis: 1) autores e legisladores; 2) promulgação; e 3) quem está sujeito. A diferença entre lei natural e lei civil aparece no primeiro critério: por ele, leis dividem-se em leis naturais e divinas (estas tendo por autor e legislador Deus) de um lado - "Quanto à primeira divisão das leis em divina, naturais e civis, os primeiros dois tipos são uma e a mesma lei" ${ }^{, 560}$ - e em leis civis (estas tendo por autor e legislador o soberano civil).

E um ponto que permite vislumbrar a relação entre as duas leis é que na ausência da lei civil a lei natural é chamada para atuar. As leis civis não podem versar sobre todos os assuntos. Com isso, "as leis de tempos em tempos serão ordenadas"561. Em função disso, “nestes casos, em que nenhuma lei especial é feita, a lei de natureza mantém o seu lugar, e os magistrados devem dar suas sentenças de acordo com ela, isto é, de acordo com a razão natural" ${ }^{, 562}$. Quando a lei civil não trata do assunto, usa-se a lei de natureza. Com isso, tem-se que

\footnotetext{
${ }^{559}$ Elementos, Parte II, capítulo X, § 5, p. 69.

${ }^{560}$ Elementos, Parte II, capítulo X, $\S 7$, p. 69.

${ }^{561}$ Elementos, Parte II, capítulo X, § 10, p. 69.

${ }^{562}$ Elementos, Parte II, capítulo X, § 10, p. 69.
} 
as constituições, portanto, do poder soberano, pelas quais a liberdade da natureza é privada, são escritas, porque não existe outra maneira de se tomar conhecimento delas; ao passo que as leis de natureza estão supostamente inscritas no coração dos homens. As leis escritas, portanto, são as constituições expressas de uma república; e as inscritas são as leis de razão natural ${ }^{563}$.

O tema das relações entre lei natural e lei civil é muito mais desenvolvido em Do cidadão do que nos Elementos. Com efeito, em Do cidadão são diversas as relações que Hobbes estabelece entre os dois tipos de lei.

Tais relações, entretanto, mais uma vez demoram a aparecer. O que é bastante compreensível, pois para relacionar dois conceitos deve-se, anteriormente, tratar desses dois conceitos. Nos Elementos, por exemplo, a lei civil só foi objeto principal de investigação no último capítulo do livro.

Apesar de não tratar imediatamente das relações entre lei natural e lei civil em Do cidadão, antes de chegar a esse tema Hobbes faz algumas aproximações entre as duas noções. Logo no início da segunda parte do livro, por exemplo, o filósofo afirma que

É um dito corrente que todas as leis silenciam em tempo de guerra, e é verdade, não apenas falando das leis civis mas também das naturais, desde que nos refiramos às ações, e não à mente, dos homens ${ }^{564}$.

\footnotetext{
${ }^{563}$ Elementos, Parte II, capítulo X, § 10, p. 69.

${ }^{564}$ Do cidadão, pp. 91 e 92.
} 
As duas leis, em igual medida, não obrigam em tempo de guerra - a lei natural não obriga porque seu cumprimento faria do homem presa fácil dos inimigos, a lei civil não obriga porque na guerra não há um poder soberano forte o suficiente para garantir a obediência. Contudo, as leis naturais continuam obrigando - apenas no plano interno, da consciência.

Um ponto relevante é que é pela lei civil que a lei de natureza é especificada. Ou seja: a lei natural determina ser proibido roubar, já que o roubo leva à desordem, Contudo, a lei natural não é capaz de determinar exatamente o que vem a ser o roubo. Isso é missão da lei civil. Como afirma Hobbes, “[o] roubo, o assassínio e todas as injúrias são proibidos pela lei de natureza, mas o que há de se chamar roubo, assassínio, adultério ou injúria a um cidadão não se determinará pela lei natural, porém pela civil" ${ }^{\text {565 }}$. É como quando o pai proíbe o filho de chegar tarde em casa. O que é exatamente chegar tarde? Depois da meia-noite? Depois das três da manhã? Isso só será determinado por alguém - por exemplo, pela mãe. Precisamente, dado o caráter de medida da lei civil, "o que é nosso e o que é dele compete à lei civil dizer" ${ }^{\circ 66}$. Aqui, é como se a lei civil completasse aquilo que a lei natural, genérica por natureza, não pode especificar em pormenor. Uma supre a outra, uma completa a outra. Tanto nas pequenas coisas da vida como nas grandes questões: “[s]e a lei civil delibera até nas minúcias, o que se dirá sobre questões maiores, como, por exemplo, como devemos entender

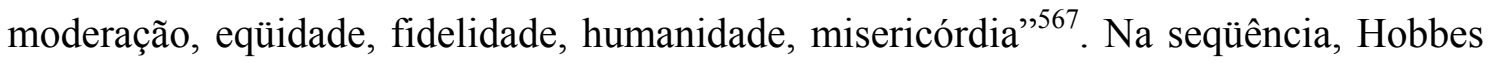
apresenta alguns exemplos - sobre os espartanos - para corroborar sua afirmação: os crimes todos (e os contratos, pactos e injúrias) são conforme definidos pela lei civil. Após apresentar o conceito e prová-lo por meio de exemplos, Hobbes conclui repetindo

\footnotetext{
${ }^{565}$ Do cidadão, p. 112.

${ }^{566}$ Do cidadão, p. 112.

${ }^{567}$ Marcelo Gross VILLANOVA, Lei natural e lei civil na filosofia política de Thomas Hobbes, p. 34.
} 
o conceito: “[p]ortanto, o que é o roubo, o assassínio, o adultério, e de modo geral a injúria, deve ser dito pelas leis civis, isto é, pelas ordens daquele que possui a autoridade suprema" ${ }^{968}$.

E se a lei civil for contrária à lei de natureza? Hobbes analisa a situação em Do cidadão: a princípio, o soberano não pode cometer injúria contra os súditos, já que ele não é parte do pacto; não sendo parte do pacto, não pode violá-lo. Entretanto, nem por isso o soberano não transgride a lei de natureza:

É verdade que o povo, os nobres e o monarca podem transgredir as outras leis de natureza de diversas maneiras, por crueldade, iniqüidade, contumélia e outros vícios análogos, que não caem sob essa definição precisa e estrita de 'injúria' ${ }^{569}$.

O soberano, de fato, não é preso à lei civil, como esta passagem bem atesta: "é evidente que ele [o soberano] não está preso a suas leis, porque ninguém está preso a si mesmo" ${ }^{, 570}$. Mas continua sempre sob o manto da lei de natureza, devendo aplicá-la quando governar.

A esse respeito, falando dos deveres do governante, Hobbes explica: "[t]odos os deveres dos governantes estão contidos nesta única sentença: a segurança do povo é a lei suprema"571. O motivo disso é determinado pela lei de natureza, da qual nenhum soberano pode escapar: “[p]orque (...) têm eles [os governantes] porém em todas as coisas o dever, na medida de suas possibilidades, de obedecer à razão reta , que é a lei natural, moral e divina"572. E a maneira pela qual o governante obedece à lei de natureza, protegendo e dando segurança para seus súditos, é por meio das leis civis:

\footnotetext{
${ }^{568}$ Do cidadão, p. 113.

${ }^{569}$ Do cidadão, p. 128.

${ }^{570}$ Do cidadão, p. 186.

${ }^{571}$ Do cidadão, p. 198.

${ }^{572}$ Do cidadão, p. 198.
} 
“[p]ois o governante (enquanto tal) não cuida da segurança de seu povo a não ser por meio de suas leis, que são universais" ${ }^{, 573}$. Portanto, a lei de natureza manda o soberano editar leis civis. Em última instância, o fundamento das leis civis repousa nas leis de natureza $^{574}$. Por isso mesmo é que essas não podem nunca ser contrariadas por aquelas. Sendo assim, é necessário que o governante edite "leis salutares, em estabelecer o bemestar (welfare) da maior parte ${ }^{, 575}$. Hobbes é bem específico nesse ponto, dizendo até mesmo que o governante deve prover, por exemplo, o conforto de seus governados:

Portanto, quem assumiu a administração do poder nessa espécie de governo pecaria contra a lei de natureza (porque pecaria contra a confiança dos que lhe confiaram tal poder), se não estudasse os meios, que forem viáveis através de boas leis, para aprovisionar em abundância os súditos não apenas com as boas coisas relativas à vida, mas também com aquelas que aumentam o seu conforto ${ }^{576}$.

A exigência por boas leis civis é um imperativo da lei de natureza. O capítulo de Do cidadão que trata dos deveres do soberano ${ }^{577}$ é, inclusive, ele todo um manual de como devem ser as boas leis civis a serem editadas pelo soberano, com Hobbes recomendando até mesmo que leis ordenem que não se gaste muito com comida ou roupas. É interessante notar a relevância que Hobbes dá para as leis civis como forma de ordenação da vida social: "apesar da tentativa de Hobbes de construir uma teoria

\footnotetext{
${ }^{573}$ Do cidadão, p. 199.

${ }^{574}$ Esse ponto já está presente em Grócio. Nos prolegômenos ao Direito da guerra e da paz, o jurista holandês defende que a obrigação de obedecer ao direito civil é decorrente da obrigação natural de cumprir os compromissos. Locke viria a utilizar o mesmo argumento no Segundo tratado, determinando que "as leis municipais dos países, as quais só são verdadeiras se baseadas na lei da natureza, mediante a qual são reguladas e interpretadas". John LOCKE, Dois tratados sobre o governo, p. 391.

${ }^{575}$ Do cidadão, p. 199.

${ }^{576}$ Do cidadão, p. 199.

${ }^{577}$ Do cidadão, capítulo XIII.
} 
absolutista, ele concebe o Estado como um rechstaat ${ }^{578}$ que opera mais pela lei do que por despotismo" 579 . Em suma, "[a]ssim, como tais leis são benéficas para os fins acima especificados, também é ofício dos magistrados supremos decretá-las” ${ }^{, 500}$. É a lei natural que manda o soberano civil decretar boas leis civis. Inclusive isso é necessário, pois, se as leis civis não forem corretamente postas e aplicadas, a paz estável não é possível, retornando-se assim ao estado natural de guerra de todos contra todos. É o que acontece se os soberanos "deixarem com freqüência de aplicar as penas impostas pelas leis" 581 . Disso Hobbes depreende que

Por conseguinte, a lei de natureza dita esse preceito aos comandantes supremos: que não apenas eles mesmos façam justiça (righteousness), mas que também, por penalidades que fixarão, forcem os juízes por eles nomeados a agir da mesma forma ${ }^{582}$. A princípio, portanto, não há oposição entre lei natural e lei civil no sistema hobbesiano. A questão clássica de qual prepondera não deveria ocorrer, já que a lei natural é fundamento da lei civil. Então tudo o que for determinado pela lei civil tem fundamento na lei natural. “A lei civil (...) se torna um conteúdo explícito e promulgado da lei de natureza. É nesse sentido que a lei civil implica em e depende das leis de natureza: a justificativa para a imperatividade da lei civil é a obrigação da lei natural de justiça: o súdito concordou em obedecer ao soberano" ${ }^{, 583}$. Seguir a lei natural é justamente obedecer à lei civil, e vice versa. De modo que "se alguém quer saber o que a lei de natureza determina, deve primeiro consultar as leis da sociedade, na medida em

\footnotetext{
${ }^{578}$ Palavra alemã que designa 'Estado de direito'.

${ }^{579}$ M. M. GOLDSMITH, Hobbes on law, p. 283.

${ }^{580}$ Do cidadão, p. 209.

${ }^{581}$ Do cidadão, pp. 212 e 213.

${ }^{582}$ Do cidadão, p. 213.

${ }^{583}$ M. M. GOLDSMITH, Hobbes on law, pp. 285 e 286.
} 
que essas leis são promulgadas publicamente" ${ }^{\text {584 }}$. Por isso Hobbes ocupa um estranho lugar nas escolas do pensamento, sendo considerado um precursor tanto do positivismo jurídico como um representante do jusnaturalismo, correntes aparentemente antinômicas $^{585}$.

Contudo, Hobbes concede que pode ocorrer de algum soberano legislar contra a lei de natureza. Nesse caso, entre lei natural e lei civil, a lei natural tem mais força, por ser lei divina ${ }^{586}$ (e Deus está acima de qualquer soberano civil) e por ser o fundamento da lei civil (caso resolvido pela hierarquia). No caso da monarquia, é fácil determinar quem infringiu a lei de natureza se uma lei civil for promulgada contra ela é sempre o monarca, único legislador legítimo. Mas e numa democracia ou numa aristocracia? Todos são responsáveis ou apenas os que efetivamente defenderam a medida e foram responsáveis pela sua aprovação? Hobbes fica com a segunda opção. Seu argumento:

numa democracia ou aristocracia, se algo for decretado infringindo alguma lei de natureza, o pecado não é culpa da cidade em si mesma (isto é, da pessoa civil), mas apenas daqueles súditos graças a cujos votos a medida foi aprovada: pois o pecado resulta da vontade natural e expressa, não da vontade política, que é artificial; e, se não fosse assim, acabariam sendo culpados pelo decreto até aqueles que o detestaram. Já numa monarquia, se o príncipe baixar algum decreto contra as leis de

\footnotetext{
${ }^{584}$ M. M. GOLDSMITH, Hobbes on law, p. 285.

${ }^{585}$ Cf. Marcelo Gross VILLANOVA, Lei natural e lei civil na filosofia política de Thomas Hobbes, p. 17. E também BOBBIO, Thomas Hobbes, p. 69.

586 "À lei natural é atribuído como sendo o mesmo que as leis divinas, o que se poderia imaginar que, dessa forma, elas adquiram uma legitimidade mais forte do que as leis meramente convencionadas pela cidade civil". Marcelo Gross VILLANOVA, Lei natural e lei civil na filosofia política de Thomas Hobbes, p. 43.
} 
natureza, pecará ele mesmo, porque nele a vontade civil e natural são uma só ${ }^{587}$.

Diferenças e semelhanças entre lei de natureza e lei civil são tratadas por Hobbes a partir de sua análise da lei civil ${ }^{588}$. Ao comparar lei e pacto, insiste em dizer que Aristóteles erra em sua definição de lei. Esta seria adequada apenas à lei civil, não valendo para a lei divina ou para a lei natural. A comparação ocorre nos seguintes termos: "[c]onfunde lei com pacto quem imagina que as leis nada mais sejam do que certos omologémata, ou formas de vida determinadas pelo consentimento comum dos homens" ${ }^{\text {"589 }}$. Não são então dadas pelo consentimento comum dos homens. Entre esses que se confundem está Aristóteles, que assim define a lei: “a lei é um discurso, cujos termos são definidos pelo consentimento comum da cidade, que declara tudo o que devemos fazer" ${ }^{, 50}$. É por isso que Hobbes afirma posteriormente ${ }^{591}$ que Aristóteles deveria definir a lei como o discurso que expressa a vontade - e não o consentimento da cidade. Todavia, parece que Hobbes emprega o termo cidade, nas duas situações, de forma diferente. Em uma, a vontade corresponde ao poder soberano, ao passo que em outra diz respeito ao conjunto dos cidadãos. A partir disso é que desponta a diferença entre a lei civil, mutável, e a lei natural, eterna:

Mas esta definição não cobre a lei em geral, porém apenas a lei civil. É manifesto que as leis divinas não provêm do consentimento dos homens, nem tampouco as leis de natureza. Pois, se elas tivessem origem no consentimento dos homens, pelo mesmo

\footnotetext{
${ }^{587}$ Do cidadão, pp. 128 e 129.

${ }^{588}$ Do cidadão, capítulo XIV, Das leis e dos crimes.

${ }^{589}$ Do cidadão, p. 216.

${ }^{590}$ Do cidadão, p. 216.

591 "Aristóteles deveria, pois, assim definir a lei civil como um discurso, cujos termos são definidos pela vontade da cidade, ordenando tudo o que deve ser feito". Do cidadão, p. 217.
} 
consentimento poderiam também ser revogadas; mas são imutáveis ${ }^{592}$.

Na seqüência, Hobbes adverte que nem para a lei civil essa definição é adequada, uma vez que ela é dada pelo legislador, e não por consentimento dos súditos (que podem discordar da lei civil, mas mesmo assim ficam obrigados a segui-la).

Posteriormente, Hobbes trata de como a lei civil, da mesma maneira que descrito nos Elementos, ocupa os espaços da lei de natureza. A lei civil é mais específica que a lei de natureza. Com isso, ela limita mais ações que as limitadas pela lei de natureza.

Mas ela [a liberdade natural] se vê restringida, primeiro, pelas leis naturais e divinas; seu resíduo depois é limitado pela lei civil; e o que ainda resta pode ainda conhecer restrições na constituição de cada município (town) ou sociedade particular ${ }^{593}$.

A lei civil ocupa, como Hobbes defende, um campo residual: o que não é limitado pela lei natural pode vir a ser pela lei civil. Mas, de modo contrário, a lei civil nunca pode ir contra a lei natural - ou seja, não pode permitir o que esta proíbe. Por exemplo: pela lei natural uma mulher não está impedida de dançar funk. Mas pela lei civil ela pode ficar proibida de dançar funk. Por outro lado, se a lei natural pró́be um homem de prestar falso testemunho, a lei civil nunca poderá autorizá-lo. É como se existisse antes de tudo a liberdade natural. A partir disso, uma primeira restrição a ela seria dada pela lei natural. Uma segunda restrição seria a das leis civis. E uma terceira a de uma ordem particular. Por exemplo: a liberdade natural deixa um homem fazer tudo. A lei natural não o deixa beber muita cerveja (para não ficar embriagado). A lei civil da sua cidade não o deixa beber nenhuma cerveja que tenha álcool. E uma ordem particular não o

\footnotetext{
${ }^{592}$ Do cidadão, p. 216.

${ }^{593}$ Do cidadão, p. 218.
} 
deixa nem tomar cerveja sem álcool. Coitado. Seriam então feixes, normas numa mesma hierarquia, cada qual no seu local. A lei natural seria uma peneira de buracos maiores, que seguram apenas as pedras maiores. A lei civil seria uma segunda peneira, mais apertada, que segura pedras de tamanho mediano. E a lei particular seria a última barreira, que impede a passagem até mesmo de pedras pequenas, permitindo apenas a saída de areia.

No momento do texto em que trata das leis divinas, a partir do Decálogo, Hobbes defende que o conteúdo dos Dez Mandamentos equivale ao das leis civis. Não pode haver desarmonia entre eles ${ }^{594}$. Aproveita para deixar claro mais uma vez que com a lei natural ocorre o mesmo processo:

As leis naturais já ordenam estas mesmas coisas, mas apenas implicitamente; pois - como dissemos no capítulo III, parágrafo 2 - a lei de natureza nos manda cumprir os contratos, e portanto também prestar obediência, sempre que tivermos firmado um pacto nesse sentido, e ainda respeitar os bens dos outros, quando a lei civil determinar que coisa pertence a outrem ${ }^{595}$.

A impressão é que a lei natural e a lei civil tratam da mesma coisa - como se a lei civil fosse tão somente a lei natural positivada.

Realmente, é essa a idéia que o filósofo desenvolve logo a seguir, ao tratar da noção de que é impossível a lei civil ordenar o que quer que seja contrário à lei

\footnotetext{
${ }^{594}$ A mesma idéia, de que as leis divinas devem corresponder às leis civis, é postulada também no De homine. Hobbes defende que "[s]e religião, além de consistir na piedade natural, não depende de pessoas privadas, com os milagres tendo cessado, devem depender das leis do Estado [state]. E sendo a religião distinta da filosofia, e valendo em todos os Estados a lei; e nessa questão ela [a lei] não deve ser discutida, mas sim observada". De homine, XIV, § 4, p. 72.

${ }^{595}$ Do cidadão, p. 222.
} 
de natureza ${ }^{596}$. Se o que define a lei, em oposição ao contrato, é que a obrigação de obediência independe da aceitação do conteúdo,

considerando pois que a nossa obrigação de respeitar tais leis antecede sua própria promulgação, estando incluída já na constituição da cidade (em virtude da lei natural que nos proíbe de romper os pactos por nós firmado), a lei de natureza manda-nos observar todas as leis civis ${ }^{597}$.

Já que a lei natural manda obedecer aos contratos celebrados, e as leis civis foram promulgadas por um soberano levado à soberania por um contrato entre os indivíduos em estado de natureza, a lei natural manda, por extensão, que esse soberano seja obedecido, bem como suas leis. Mais uma vez a concepção, cada vez mais forte, que obedecer a lei civil é o mesmo que obedecer a lei natural. A conseqüência disso para a conduta do cidadão é importante: a lei deve ser obedecida independentemente do seu conteúdo. Deve ser seguida apenas porque é lei, editada pelo poder soberano, "pois, quando estamos obrigados a obedecer antes mesmo de saber o que vão nos mandar, estamos totalmente obrigados a obedecer em todas as coisas" ${ }^{\text {"598 }}$. Com isso, o súdito deve obedecer sempre a lei civil, mesmo quando discordar dela, mesmo quando ela manda fazer algo para ele considerado errado e, pior ainda, mesmo quando ela manda matar ou roubar. O motivo:

Segue-se, portanto, que é impossível qualquer lei civil que não tenda a ofender a Divindade (em face de quem as próprias cidades não têm direito que

\footnotetext{
${ }^{596}$ Do cidadão, capítulo XIV, § 10, p. 69.

${ }^{597}$ Do cidadão, p. 223.

${ }^{598}$ Do cidadão, p. 223.
} 
lhes seja próprio, e não se pode dizer que façam leis) infringir a lei de natureza ${ }^{599}$.

Há aqui apenas uma limitação - a lei civil não pode ofender a Divindade. O que significa, indiretamente, ir contra a lei de natureza, já que esta é colocada pela própria Divindade. E a lei civil que ofende a Divindade? Essa nem mesmo pode ser considerada lei civil, já que, como afirma Hobbes, contra a Divindade não há direito e nem lei. É, em todo caso, uma passagem um tanto estranha e bastante controvertida, pois Hobbes afirma pouco antes que a lei civil deveria ser obedecida sempre, por seu conteúdo equivaler ao da lei natural. É a posição de Renato Janine Ribeiro, que ressalta, em nota, dois pontos: primeiramente, que se trata de "passagem que tende a contradizer o que Hobbes afirma em outros lugares" $" 600$; e em segundo lugar que "Hobbes evita desenvolver aqui o assunto"601. Em todo caso, Hobbes procura provar sua assertiva por meio de exemplos. Em primeiro lugar, um exemplo geral (sobre roubo ou adultério). Em segundo lugar, um exemplo dentro do exemplo (roubo em Esparta e sexo entre pagãos). A partir do primeiro exemplo, mais geral, Hobbes argumenta que se a lei civil manda roubar, essa ação não será considerada roubo. Por quê? Hobbes já havia adiantado as razões anteriormente, e as repete agora. É a lei civil que especifica o que a lei natural manda dizer. A lei natural diz que é proibido roubar, mas não diz exatamente em que consiste o roubo - isso é assunto para a lei civil. Para o filósofo, a lei civil não pode por princípio contrariar a lei natural. Sendo assim, tudo que ela fizer por conseqüência não vai contrariar a lei natural. Em conclusão, Hobbes procura deixar claro aqui como a lei civil não pode nunca, por questão de princípio, contrariar a lei natural. Caso contrarie (como no caso mencionado de desrespeitar a Divindade), certamente não é lei civil. Todavia, Hobbes não diz quem é qualificado para julgar se

\footnotetext{
${ }^{599}$ Do cidadão, p. 223.

${ }^{600}$ Do cidadão, nota 5, p. 287.

${ }^{601}$ Do cidadão, nota 5, p. 287.
} 
uma lei civil contraria ou não a lei divina; se o súdito puder fazê-lo, então poderá legitimamente desobedecer ao soberano, já que neste caso específico a ordem do soberano, para o súdito, não constitui lei civil. Conclusão que vai contra o sistema geral de Hobbes. Por outro lado, se o julgamento competir ao soberano, este nunca irá concluir que suas ordens ofendem a divindade. É difícil, portanto, entender os motivos que levaram Hobbes a formular a passagem.

Uma relação de completa identificação entre lei natural e lei civil é dada por Hobbes ao tratar da distinção entre lei escrita e lei não escrita. É uma passagem bastante sinuosa. O autor começa dividindo as leis civis, em razão do modo de promulgação, em escritas e não escritas ${ }^{602}$. Leis escritas são as que precisam de algum sinal suficiente representando a vontade do legislador (não precisando necessariamente serem escritas em papel; podem serem eventualmente faladas ou mesmo cantadas) ${ }^{603}$. Já a lei não escrita, por exclusão, é a que não precisa de tal sinal: "[1]ei não escrita é aquela que não necessita de outra promulgação além da voz da natureza ou da razão natural; dessa espécie são as leis de natureza" ${ }^{\natural 04}$. A passagem, de início, soa bastante estranha: dá a entender que a lei de natureza é uma espécie da lei civil, o que vai contra tudo o que fora afirmado até então. $O$ que Hobbes afirma na seqüência, para justificar a passagem, é que a lei natural é ao mesmo tempo distinta mas também semelhante à lei civil: "[p]ois a lei de natureza embora se distinga da lei civil, na medida em que ela governa a vontade, é contudo civil na medida em que se refere a nossas ações" ${ }^{\circ 05}$. O que isso quer dizer? Que a lei natural se distingue da lei civil por dizer respeito ao foro interno, governando a consciência e a vontade, e não a ação, já estava devidamente estabelecido anteriormente. O que causa estranhamento é a afirmação de que a lei

\footnotetext{
${ }^{602}$ Do cidadão, p. 226.

${ }^{603}$ Do cidadão, p. 226.

${ }^{604}$ Do cidadão, pp. 226 e 227.

${ }^{605}$ Do cidadão, p. 227.
} 
natural é civil por se referir às nossas ações. Até então, era justamente o contrário. A lei de natureza governa nossa vontade e não nossas ações; a lei civil governa nossas ações e não governa nossa vontade. A lei de natureza até governaria nossas ações, se tal fosse possível; mas, no estado de natureza, isso faria do homem presa fácil - sendo necessária, para suprir tal deficiência, justamente a criação do Estado civil, em que as leis naturais, agora convertidas em lei civil, poderiam ser obedecidas com segurança suficiente. Mas a lei de natureza, diz Hobbes, se refere a nossas ações. Indiretamente, certamente que sim, pois nossas ações estão condicionadas por nossas vontades (vide a teoria das paixões de Hobbes, com a noção dos movimentos do coração e do cérebro levando aos movimentos do corpo). Dessa forma, pode-se tentar compreender a passagem da seguinte maneira: a lei de natureza diz respeito à nossa vontade, que acaba atuando nas nossas ações. Por isso a lei natural refere-se, embora não diretamente, às nossas ações. Dessa forma a lei de natureza acaba compartilhando um mesmo aspecto da lei civil. Para justificar a assertiva, Hobbes oferece um exemplo: “o mandamento não cobiçarás, que se refere somente à intenção, é apenas uma lei natural; já o mandamento não roubarás constitui lei tanto natural como civil’606. O exemplo, felizmente, é bastante ilustrativo. O primeiro mandamento é apenas uma lei natural, já que diz respeito somente à vontade, e não às ações. $\mathrm{O}$ segundo mandamento, por sua vez, diz respeito tanto às ações quanto à vontade (para cometer a ação de roubar deve-se ter a vontade de roubar). Então é lei civil e lei natural ao mesmo tempo. O que quer dizer que a lei civil tem sempre que ser lei natural também, pois as ações passíveis de punição (as voluntárias) estão sempre condicionadas à vontade. É isso o que ele afirmou anteriormente: que as duas leis, natural e civil, não são excludentes. Elas não têm âmbitos de atuação necessariamente distintos. Uma pode estar onde a outra não está,

\footnotetext{
${ }^{606}$ Do cidadão, p. 227.
} 
mas elas podem muito bem (e em certos casos devem) estar juntas. Então, explicando a passagem anterior, uma lei natural pode ser civil também enquanto ela regula nossas ações.

A partir disso, Hobbes não tem dificuldade em concluir na seqüência que, do mesmo modo que a lei civil atua na ausência da lei de natureza, a lei de natureza - como expresso também nos Elementos - deve ocupar os espaços vazios deixados pela lei civil.

Considerando assim que é impossível prescrever tantas regras universais que possam determinar todas as pendências que venham a surgir no futuro (e que podem ser em número infinito), é de entender que em todos os casos não mencionados nas leis escritas devemos seguir a lei da eqüidade natural, que nos ordena distribuir igualmente entre iguais; e isso em virtude da lei civil, que também pune aqueles que de maneira consciente e deliberada transgridem as leis de natureza ${ }^{607}$.

É claro que não é possível haver leis civis para regular todas as condutas imagináveis. A expressão regras universais possui aqui o sentido de lei civil. Sendo que as leis civis não podem regular todas as situações, o que deve ser feito? O jeito é seguir, nos casos de lacuna do ordenamento ou omissão legislativa, o que diz a lei natural ${ }^{608}$. Há aqui uma relação importante entre lei natural e lei civil. No silêncio da lei civil, fala a lei natural. É como se esta fosse uma retaguarda daquela. Hobbes defende que é a lei da eqüidade natural que nos manda distribuir igualmente entre os iguais. É precisamente esse o conteúdo da lei natural que regula a eqüidade. O que é definido também pela lei civil, já

\footnotetext{
${ }^{607}$ Do cidadão, p. 227.

608 "O trecho faz referência a um vácuo regulativo da lei positiva às ações dos Subjects, não por uma falha da regulação, mas pela impossibilidade prática de fazê-lo". Marcelo Gross VILLANOVA, Lei natural e lei civil na filosofia política de Thomas Hobbes, p. 63.
} 
que ela tem como função regular o que dizem as leis naturais. Desse modo, é bastante claro que a lei natural não é abandonada a partir da instituição do Estado civil ${ }^{609}$.

Posteriormente, ao discutir o pecado da traição, Hobbes estabelece mais uma relação entre lei natural e lei civil. "[Hobbes] diz que a lei de natureza dá algumas restrições à lei civil”, pois "toda restrição que não é uma lei pública e promulgada deve ser uma lei da natureza ou da razão"610 . O filósofo defende que traição é contrariar a lei de natureza, e não a lei civil: "'[m]as o pecado que pela lei de natureza constitui traição é a transgressão da lei natural, e não da lei civil" ${ }^{\prime 611}$. O autor justifica sua afirmação tendo em vista a relação entre as duas espécies de lei:

Como nossa obrigação de obediência civil, que é o que confere validade a todas as leis civis, precede a lei civil, e o pecado de traição nada mais é que o descumprimento de tal obrigação, segue-se que pelo pecado de traição se rompe a lei que precedia a lei civil, a saber, a lei de natureza, que nos proíbe de violar os pactos e a palavra dada ${ }^{612}$.

Nesse momento da argumentação, a lei natural é colocada mais uma vez como o fundamento da lei civil, fundamento lógico que determina a validade da lei civil, por lhe estar condicionada. Trair não é descumprir uma lei civil qualquer, mas é negar obediência ao próprio ordenamento, é não reconhecer o direito de legislar ao soberano. É, em suma, ir contra a própria lei de natureza que manda abrir mão do julgamento

\footnotetext{
609 “A formação da sociedade civil não faz tábula rasa das leis naturais. Subsumidos à lei positiva, os ditames da reta razão não são uma escada que deve ser abandonada após alcançar o estágio posterior. (...). A lei natural não desaparece sob o manto da legalidade, mas sim ela predomina em vários momentos". Marcelo Gross VILLANOVA, Lei natural e lei civil na filosofia política de Thomas Hobbes, p. 51.

${ }^{610}$ M. M. GOLDSMITH, Hobbes on law, p. 286.

${ }^{611}$ Do cidadão, p. 232.

${ }^{612}$ Do cidadão, pp. 232 e 233.
} 
privado como forma de se obter a paz e a preservação. Em função disso é que a traição não é punida pela lei civil, mas pela lei natural ${ }^{613}$.

Prosseguindo, Hobbes discute se violar a lei civil é a mesma coisa que violar a lei de natureza:

$$
\begin{aligned}
& \text { Alguns pensam que é possível expiar os atos } \\
& \text { praticados contra a lei, quando o castigo está fixado } \\
& \text { na própria lei e o punido se submete } \\
& \text { voluntariamente (unwilling) a ele; e que por isso } \\
& \text { quem tenha sofrido o castigo cominado em lei não } \\
& \text { seria culpado perante Deus, por infringir a lei } \\
& \text { natural (embora, rompendo as leis civis, tenha } \\
& \text { violado a lei de natureza que manda respeitá-las) - } \\
& \text { como se a lei não proibisse propriamente a ação, } \\
& \text { mas em vez disso fixasse o castigo sob forma de } \\
& \text { um preço }{ }^{614} \text {. }
\end{aligned}
$$

A questão consiste em saber se sofrer a punição civil já é suficiente para expiar o pecado de violar a lei natural. Hobbes, como visto, argumenta que não, pois o castigo não é apenas um preço a ser pago para se fazer o que se tem vontade. Quem deve explicar o que significa a lei é o soberano, pois sua interpretação é a única autêntica. Em caso de dúvida, o súdito não deve desrespeitá-la, sob risco de incorrer em punição.

Depende do soberano, porém, saber em que sentido se deve entender a lei. Sempre que houver qualquer dúvida sobre o significado da lei, e como quer que depois ela venha a ser explicada, será pecado infringi-la, já que pelo menos temos certeza de que não peca quem a viola ${ }^{615}$.

\footnotetext{
${ }^{613}$ Do cidadão, p. 233.

${ }^{614}$ Do cidadão, pp. 233 e 234.

${ }^{615}$ Do cidadão, p. 234.
} 
Mais que isso: desrespeitar uma lei que não se sabe exatamente o que determina é desrespeito não só à própria lei civil descumprida, mas desrespeito à própria lei de natureza: "[p]ois cometer o que não sabemos se é pecado ou não, quando temos a liberdade de evitá-lo, constitui desrespeito à lei, e portanto - pelo capítulo III, parágrafo 28 - pecado contra a lei de natureza",616.

Uma outra defesa de que a lei natural deve ser seguida ocorre quando não há ainda lei civil é presente na discussão acerca do reino de Deus antes da vinda do Salvador.

Mas não lemos que Deus tenha dado leis a Abraão, ou que Abraão as tenha dado a sua família, nessa época ou mesmo depois, fossem elas seculares ou sagradas; com uma única exceção, a do mandamento da circuncisão, que está contido no próprio pacto. Por isso se evidencia que Abraão não estava obrigado a nenhuma lei ou culto, a não ser às leis da natureza, ou do culto racional e da circuncisão $^{617}$.

Abraão estava, assim, atado apenas à lei natural, visto que não possuía um poder soberano acima de si. Por esse mesmo motivo o patriarca bíblico era também o intérprete de todas as leis ${ }^{618}$.

Uma aproximação entre lei natural e lei civil é realizada por Hobbes ao interpretar o sentido da vinda de Jesus Cristo para a Terra. Segundo o filósofo, o filho de Deus teria vindo para a Terra não para promulgar novas leis, mas sim para explicitar o que Deus queria dizer com Suas leis. Não veio como legislador, mas sim como intérprete autorizado:

\footnotetext{
${ }^{616}$ Do cidadão, p. 234.

${ }^{617}$ Do cidadão, p. 264.

${ }^{618}$ Do cidadão, p. 265.
} 
Nosso Salvador não prescreveu leis distributivas aos súditos dos príncipes, nem aos cidadãos das cidades; isto é, não deu regras com base nas quais um súdito possa conhecer e discernir o que é seu, o que é de outro; nem disse por que fórmulas, termos ou circunstâncias uma coisa deve ser dada, entregue, ocupada ou possuída, de modo que possamos saber que ela pertence legalmente a quem a recebe, ocupa ou possui ${ }^{619}$.

E, em sua interpretação das leis de Deus, Jesus demonstrou que a lei natural e as leis civis podem ser resumidas numa mesma fórmula: "todas as leis naturais e civis estão nessa fórmula, Amarás o teu próximo como a ti mesmo. Pois quem ama a Deus e a seu próximo tem em mente obedecer a todas as leis, tanto as divinas quanto as humanas"620. Lei natural e lei civil são tratadas aqui como se fossem exatamente a mesma coisa. $\mathrm{O}$ que a lei de Cristo, ou seja, a lei de natureza, manda é obedecer à lei civil:

Disso se segue, portanto, que por estas leis - Não matarás, Não cometerás adultério, Não roubarás, Honrarás pai e mãe - tudo o que se ordenou foi que os súditos e cidadãos obedecessem absolutamente a seus príncipes em todas as questões referentes ao meum e ao tuum, ao que constitui direito deles e ao que é direito alheio ${ }^{621}$.

Dessa forma, “[p]or conseguinte, a lei de Cristo sobre o homicídio (e conseqüentemente toda forma de dano que se cause a alguém, e quaisquer penalidades que possam ser instituídas) manda que obedeçamos tão-somente à cidade"622; e ainda: "que só se chame

\footnotetext{
${ }^{619}$ Do cidadão, p. 296.

${ }^{620}$ Do cidadão, p. 295.

${ }^{621}$ Do cidadão, p. 297.

${ }^{622}$ Do cidadão, p. 297.
} 
de assassínio, adultério ou roubo o que é contrário às leis civis" ${ }^{\text {"23 }}$. Em suma, o que Jesus de Nazaré disse foi, segundo Hobbes, que a lei de natureza deve ser obedecida pela obediência às leis civis: “[a]demais, como nosso Salvador não apontou aos súditos nenhuma outra lei para o governo das cidades além das leis de natureza, isto é, nenhuma além do mandamento de obediência"624. Realmente, para a salvação da alma é necessário obedecer tanto a lei civil como a lei natural, como fica bem claro nesta passagem que resume a obra de Jesus:

A suma do ofício de Nosso Salvador consistiu em ensinar a via e todos os meios para a salvação e a vida eterna. A justiça e a obediência civil, bem como a observância de todas as leis naturais, constituem um dos meios para a salvação. E eles podem ser ensinados de duas maneiras: primeira, como teoremas, pela via da razão natural, derivando-se o direito e as leis naturais de princípios e contratos humanos; a doutrina assim transmitida está sujeita à censura pelos poderes civis. A outra maneira é como leis, por autoridade divina, mostrando que a vontade de Deus é tal ou qual; ensinar desta maneira pertence apenas àquele que conhece pela via sobrenatural a vontade de Deus - isto é, apenas o Cristo ${ }^{625}$.

As cogitações envolvendo relações entre lei natural e lei civil demoram a aparecer no texto do Leviatã. Hobbes inclusive adianta, numa passagem anterior: "[m]as

\footnotetext{
${ }^{623}$ Do cidadão, p. 298.

${ }^{624}$ Do cidadão, p. 298.

${ }^{625}$ Do cidadão, pp. 300 e 301.
} 
em que casos as ordens do soberano são contrárias à eqüidade e à lei de natureza é coisa que será examinada adiante em outro lugar" ${ }^{\circ 26}$.

A primeira - e principal - passagem, complicadíssima, aparece numa das considerações que Hobbes faz após definir a lei civil.

Hobbes já inicia a quarta das considerações com uma afirmação categórica: "4. A lei de natureza e a lei civil contêm-se uma à outra e têm igual alcance"627. É sem dúvida um ponto bastante complicado: "a solução que [Hobbes] oferece é um desafio para a compreensão do leitor" ${ }^{\text {"28. }}$. O que isso quer dizer exatamente? É possível uma coisa conter a outra reciprocamente? É possível, desde que ambas tenham a mesma extensão. Coisas com extensão diferente não podem conter-se reciprocamente: um chapéu pode conter uma cabeça, mas uma cabeça não pode conter um chapéu; a ONU contém o Brasil, mas o Brasil não contém a ONU. Mas em casos de igual extensão é possível: uma fronteira contém uma extensão de terra, e a extensão de terra contém a fronteira. É o que Hobbes quer dizer ao afirmar que a lei de natureza e a lei civil têm igual alcance ${ }^{629}$. Pois coisas de alcance diferente não se contêm reciprocamente. Em relação ao tema específico das leis natural e civil, isso pode representar alguns problemas, em face do que Hobbes havia explicado a respeito delas. Ele defende aqui que lei natural e lei civil possuem o mesmo alcance, isto é, abrangem as mesmas coisas. O filósofo havia deixado bem claro, entretanto, que isso não é necessário. É perfeitamente possível, segundo ele próprio, haver uma lei civil que não seja uma lei natural. Por exemplo, não há lei natural dizendo de quanto deve ser a

\footnotetext{
${ }^{626}$ Leviatã, p. 212.

${ }^{627}$ Leviatã, p. 227.

${ }^{628}$ Marcelo Gross VILLANOVA, Lei natural e lei civil na filosofia política de Thomas Hobbes, p. 17.

629 "Não há nenhuma dificuldade lógica envolvida em dizer-se que dois termos, como lei natural e lei civil, que têm conotações diferentes, tenham a mesma extensão, embora termos como extensões diferentes não possam ter a mesma conotação". Marcelo Gross VILLANOVA, Lei natural e lei civil na filosofia política de Thomas Hobbes, p. 76.
} 
porcentagem de juros num empréstimo. Por outro lado, Hobbes também afirmou que a lei civil não pode nunca ir contra a lei natural. Não pode haver uma taxa de juros que seja manifestamente injusta, ou seja, que contrarie a lei de natureza. O problema é que a justiça não é definida pela lei natural, mas sim pela lei civil. É a lei civil que regula a taxa de juros que vai determinar que a taxa é justa, exatamente porque foi ela mesma que a regulou. Com isso, a lei civil, por sua própria definição, está sempre de acordo com a lei de natureza; pois, caso não esteja, deixa de ser lei civil. Ela sempre determina o mesmo que a lei de natureza: não pode nunca ser diferente ${ }^{630}$. É isso o que Hobbes entende ao expressar que ambas contêm-se uma à outra e possuem o mesmo alcance. "Ele [Hobbes] parece querer dizer que a lei civil é a exposição emanada com autoridade [authoritative] da lei de natureza em qualquer sociedade" ${ }^{, 631}$. Uma outra colocação pode ser feita tendo em vista a afirmação de que a lei natural não é exatamente uma lei, por não ser uma ordem e sim uma recomendação. Se neste caso, vista como mero ditame racional, ela se afasta da lei civil, por possuir uma natureza diferente, mas quando vista como comando divino ela aproxima-se da lei civil, desfrutando ambas da mesma natureza de lei em sentido estrito.

Galhofas e mais galhofas:

Porque as leis de natureza, que consistem na eqüidade, na justiça, na gratidão e outras virtudes morais destas dependentes, na condição de simples natureza (conforme já disse, no final do capítulo $\mathrm{XV}$ ) não são propriamente leis, mas qualidades que predispõem os homens para a paz e a obediência ${ }^{632}$.

\footnotetext{
630 "O conjunto das leis de natureza com revestimento divino identifica-se com o mandamento da obediência civil, isto é, com o que diz a lei civil. Essa parece ser uma explicação razoável para a afirmação de que os dois ordenamentos terem idêntica extensão e conter-se reciprocamente". Marcelo Gross VILLANOVA, Lei natural e lei civil na filosofia política de Thomas Hobbes, p. 35.

${ }^{631}$ M. M. GOLSMITH, Hobbes on law, p. 285.

${ }^{632}$ Leviatã, p. 227.
} 
Aqui Hobbes novamente repete o que havia considerado anteriormente, que leis naturais não são propriamente leis. Elas são qualidades (um termo que ele ainda não havia utilizado), ou seja, atributos que levam o homem a agir em determinado sentido. Mas a afirmação não é exatamente a mesma de antes - ele defende agora que leis naturais não são leis na condição de simples natureza, isto é, no estado de natureza. Pois no estado de natureza não há ainda leis em sentido próprio. Agora, quando há república e poder soberano é que as leis de natureza podem efetivamente ser alçadas à condição de leis em sentido estrito, pois seu conteúdo passa a ser regulado pelas leis civis. Elas tornam-se leis caso o soberano assim determinar - e é o que ele deve fazer.

É isso o que Hobbes afirma em seguida:

Só depois de instituída a república elas [as leis naturais] efetivamente se tornam leis, nunca antes, pois passam então a ser ordens da república, portanto também leis civis, na medida em que é o poder soberano que obriga os homens a obedecerlhes ${ }^{633}$.

Isso é correto, mas apenas na medida em que o soberano postule as leis naturais enquanto leis civis. Uma objeção aqui poderia ser levantada. Pois, dentre as leis naturais, há algumas cujo cumprimento não pode ser regulamentado por lei civil. É bem possível, inclusive necessário, que a lei civil determine que contratos sejam cumpridos. Mas, por outro lado, não é possível uma lei civil que mande um homem ser caridoso ou grato. A distinção pode ser pensada segundo a regulamentação da ação ou da intenção pela lei natural. Se a lei natural determina algo que se manifeste no campo da ação (como não roubar, não matar, cumprir sua parte numa venda), ela deve ser positivada pelo soberano. Mas se o que ela comanda é restrito às disposições de consciência (como

\footnotetext{
${ }^{633}$ Leviatã, pp. 227 e 228.
} 
no caso da gratidão e da caridade; se a caridade fosse obrigatória por lei, deixaria de ser caridade), a lei natural não é passível de se transformar em lei civil. O que poderia causar uma complicação, tendo em vista o afirmado de que lei natural e lei civil possuem o mesmo alcance - no exemplo da gratidão, uma das leis a alcança, mas a outra não, parecendo haver, aqui, um alcance diferente das áreas reguladas por elas.

$\mathrm{Na}$ seqüência do texto, Hobbes prossegue desenvolvendo que as leis naturais somente são leis civis se positivadas:

Porque para declarar, nas dissensões entre particulares, o que é eqüidade, o que é justiça e o que é virtude moral, e torná-las obrigatórias, são necessárias as ordenações do poder soberano, e punições estabelecidas para quem as infringir, ordenações essas portanto que fazem parte da lei civil $^{634}$.

Realmente, são mesmo necessárias ordens do poder soberano para leis naturais valerem enquanto leis civis. Aparecem, aqui, as punições.

Disso tudo Hobbes obtém uma conclusão: “[d]esta forma, a lei de natureza faz parte da lei civil, em todas as repúblicas do mundo" ${ }^{635}$. Trata-se de uma conclusão, com base nas premissas que o filósofo acabou de mencionar. O que ele acabou de mencionar? Que para acabar com as desavenças entre os indivíduos o soberano deve dizer, por meio da lei civil, o que é a eqüidade, a justiça etc. Ou seja: que o soberano deve dizer, por meio da lei civil o que é a lei de natureza. Ele, soberano, é o autêntico intérprete da lei de natureza, dada e explicada a seus súditos por meio da lei civil. A lei de natureza é explicitada pela lei civil: ela faz parte da lei civil. Mas, apesar

\footnotetext{
${ }^{634}$ Leviatã, p. 228.

${ }^{635}$ Leviatã, p. 228.
} 
do que Hobbes afirma nesse ponto, pode-se concluir, que a lei natural não se esgota na lei civil, por dispor certos conteúdos não sujeitos à positivação.

O oposto também é verdadeiro: "[e] também, reciprocamente, a lei civil faz parte dos ditames da lei de natureza" ${ }^{\natural 36}$. A lei civil encontra-se na lei de natureza por ser necessária para os homens saírem do estado de guerra. Ela é a ordem do soberano, que tem o dever, dado pela lei de natureza, de acabar com as discórdias entre os particulares. Ele faz isso justamente dando ordens e fazendo com que elas sejam cumpridas. Ou seja, editando leis civis.

Hobbes explica: “[p]orque a justiça, quer dizer, o cumprimento dos pactos e dar a cada um o que é seu, é um ditame da lei de natureza" ${ }^{937}$. A justiça é um ditame das leis de natureza. Um dos ditames da lei de natureza manda obedecer às regras. Manda obedecer aos comandos do soberano. Manda, em outras palavras, obedecer às leis civis. A lei de natureza é quem manda que a lei civil seja obedecida. A lei civil deve, por isso, ser cumprida em função da lei de natureza. É o que o filósofo apresenta a seguir:

Ora, se os súditos de uma república fizeram a promessa de obedecer à lei civil (quer a tenham feito uns aos outros, como quando se reúnem para escolher um representante comum, quer cada um individualmente com o próprio representante quando, subjugados pela espada, prometem obediência em troca da garantia da vida); portanto, a obediência à lei civil também faz parte da lei de natureza ${ }^{638}$.

\footnotetext{
${ }^{636}$ Leviatã, p. 228.

${ }^{637}$ Leviatã, p. 228.

${ }^{638}$ Leviatã, p. 228.
} 
Hobbes coloca, assim, o fundamento da obediência à lei civil na lei natural. É necessário, então, que os homens obedeçam previamente à lei natural, para, em função dela, obedecerem à lei civil. O problema é que os homens só obedecem à lei de natureza se elas são leis civis, obrigatórias em função da espada do soberano. Parece haver uma circularidade no argumento. Talvez por isso Hobbes tenha se esforçado em tratar a lei natural como obrigatória no estado de natureza ao conferir-lhe status de comando divino (como na interpretação de Taylor e Warrender).

$\mathrm{Na}$ seqüência, é exposta uma idéia que não havia sido colocada anteriormente: “[a] lei civil e a lei natural não são diferentes espécies, mas diferentes partes da lei, uma das quais é escrita e chama-se civil, e a outra não é escrita e chama-se natural" ${ }^{139}$. Hobbes defende, anteriormente, que elas, lei natural e lei civil, se identificam. Se elas se identificam, tendo a mesma extensão, então não podem ser diferentes espécies de lei, pois atuam ambas no mesmo âmbito. Agora ele defende que não são diferentes espécies da lei, mas sim são diferentes partes da lei. Qual lei é essa? Hobbes em nenhum lugar se refere a essa lei, da qual tanto a lei natural como a lei civil são partes. Elas seriam, então, como diferentes aspectos, diferentes instâncias de uma mesma coisa. Como a cor e o tamanho do cabelo de uma mulher bonita. Ambos possuem a mesma extensão, um faz parte do outro, mas um não é o outro. Ambos são diferentes partes do todo que constitui o cabelo da mulher bonita. $\mathrm{O}$ que distingue uma lei da outra, portanto, é, para Hobbes, o fato de uma ser escrita e a outra não (entende-se aqui escrita metaforicamente, já que pode ser oral também). Há, nesse ponto, uma certa diferença em relação ao texto presente no Do cidadão, no qual Hobbes distinguia bem lei escrita e lei não escrita de lei civil e de lei natural.

Por fim, Hobbes pondera:

${ }^{639}$ Leviatã, p. 228. 
Mas o direito de natureza, isto é, a liberdade natural do homem, pode ser limitado e restringido pela lei civil; mais, a finalidade das leis não é outra senão essa restrição, sem a qual não será possível haver paz. E não foi por outra razão pela qual a lei surgiu no mundo, senão para limitar a liberdade natural dos indivíduos, de maneira tal que eles sejam impedidos de causar dano uns nos outros, e em vez disso se ajudem e se unam contra um inimigo comum ${ }^{640}$.

Como visto, a lei civil pode restringir a liberdade natural do homem. Não só pode como deve: ela, afinal, existe para isso (pois a liberdade natural é a causa das tormentas). A liberdade natural é substituída, portanto, por outro tipo de liberdade, a liberdade civil ${ }^{641}$. São duas figuras bem diferentes de liberdade: a primeira toma a liberdade como um conceito positivo, liberdade de se fazer o que quiser no estado de natureza; a segunda toma a liberdade como um conceito totalmente negativo, liberdade como ausência de oposição, liberdade no silêncio da lei ${ }^{642}$. Na primeira, o homem pode fazer tudo o que ele bem entender; na segunda, o homem só pode fazer o que não for proibido pela lei civil.

Nas considerações seguintes a respeito da lei civil, Hobbes também estabelece algumas relações entre lei natural e lei civil. Na quinta consideração, o filósofo argumenta que uma lei não escrita que seja seguida por todos é uma lei natural. Hobbes começa explicando qual lei deve ser seguida em caso de conquista de uma república por outra. É a lei da república vencedora, sem dúvida ${ }^{643}$. Mesmo que as leis escritas da república perdedora continuem vigendo, isso se dá porque elas passam a ser

\footnotetext{
${ }^{640}$ Leviatã, p. 228.

${ }^{641}$ Simone GOYARD-FABRE, Le droit et la loi dans la philosophie de Thomas Hobbes, p. 157.

${ }^{642}$ Simone GOYARD-FABRE, Le droit et la loi dans la philosophie de Thomas Hobbes, pp. 152 e 153.

${ }^{643}$ Leviatã, p. 228.
} 
toleradas e aceitas pela nova república, pois o que faz a lei, Hobbes sempre deixa claro, não é o costume, mas sim a força e autoridade do poder soberano: “[p]orque o legislador não é aquele por cuja autoridade as leis pela primeira vez foram feitas, mas aquele por cuja autoridade elas [as leis] continuam a ser feitas" ${ }^{644}$. As leis de uma república conquistada deixam de ser leis, virando costumes: “[e] se agora são leis não é devido à prescrição do tempo, e sim às constituições do atual soberano" ${ }^{\text {645 }}$. Na conclusão da exposição Hobbes defende que uma lei não escrita que seja sempre seguida trata-se, em verdade, de uma lei natural:

Mas se em todas as províncias de um domínio se verificar a observância geral de uma lei não escrita, e se no seu uso não se manifestar nenhuma iniqüidade, essa lei não pode ser outra coisa senão uma lei de natureza, igualmente obrigatória para todos os homens ${ }^{646}$.

Observa-se que os homens todos seguem uma lei não escrita e essa lei não escrita parece ser boa. A conclusão é que deve ser uma lei natural. Nesse caso, porém, o que fundamenta que tal lei seja natural é o fato dela ser obrigatória. Só que a ausência de obrigatoriedade da lei natural é justamente o que motiva a edição de leis civis - leis naturais, para Hobbes, não podem ser exigidas sem leis civis as resguardando, pois o homem viraria presa fácil. Nessa passagem, estranhamente, não há lei civil garantindo a lei natural, e no entanto ela é considerada obrigatória, por todos a cumprirem.

Após realizar as observações em torno do conceito de lei civil, Hobbes examina de que maneira a lei civil pode ser reconhecida, ou seja, quais os sinais para

\footnotetext{
${ }^{644}$ Leviatã, p. 228.

${ }^{645}$ Leviatã, p. 229.

${ }^{646}$ Leviatã, p. 229.
} 
que se conheça o que é lei. Para fazer isso, acaba tocando na relação entre lei natural e lei civil.

Em primeiro lugar, se for uma lei obrigatória para todos os súditos sem exceção, e não estiver escrita ou de algum outro modo publicada em lugares onde se possam informar, trata-se de uma lei de natureza. Porque tudo o que os homens conhecem como lei, não pelas palavras de outros homens, mas cada um através da sua própria razão, deve ser válido para a razão de todos os homens, o que não pode acontecer com nenhuma lei, a não ser a lei de natureza. Portanto, as leis de natureza não precisam ser públicas nem proclamadas, pois estão contidas nesta única sentença, aprovada por toda gente: Não faças aos outros o que não considera razoável que seja feito por outrem a ti mesmo ${ }^{647}$.

É imperativo que seja uma lei obrigatória para todos os súditos sem exceção, visto que há aquelas leis que são dirigidas apenas a alguns. Essa lei, obrigatória para todos, pode não estar escrita (ou verbalizada). A princípio, não poderia ser uma lei civil, pois ela deve estar escrita, como visto anteriormente. Se essa lei não escrita for lei mesmo, isto é, obrigatória para todos, então há de ser uma lei natural. Dessa forma, mais uma vez identificando lei civil com lei de natureza, Hobbes afirma que a lei obrigatória e não escrita só pode ser a lei natural. Outra vez a noção de que lei natural e lei civil são a mesma coisa, mudando apenas o aspecto formal (uma é escrita, a outra não). Essa lei, civil mas não escrita, que os homens devem seguir é uma lei natural:

Porque tudo o que os homens conhecem como lei, não pelas palavras de outros homens, mas cada um através da sua própria razão, deve ser válido para a

${ }^{647}$ Leviatã, p. 231. 
razão de todos os homens, o que não pode acontecer com nenhuma lei, a não ser a lei de natureza $^{648}$.

Trata-se de uma passagem importante. O que os homens conhecem como lei por meio da sua própria razão é realmente a lei de natureza, conforme sua própria definição. Trata-se do primeiro aspecto da lei de natureza, como um preceito da razão. É interessante notar que nesse ponto não pode ser lei civil, pois a lei civil é dada pela razão do soberano, e não pela razão de cada um dos homens. Essa lei de que o filósofo trata aqui tem caráter de lei civil mas distinto de lei civil. Certamente é uma lei natural. Não é lei civil, pois não é conhecida "pelas palavras de outros homens", e a lei civil é. Mas é lei, pois é obrigatória para todos os súditos. Para sair desse impasse é que Hobbes acaba colocando a lei como lei de natureza. O filósofo tira disso tudo uma conclusão:

Portanto, as leis de natureza não precisam ser públicas nem proclamadas, pois estão contidas nesta única sentença, aprovada por toda gente: Não faças aos outros o que não consideras razoável que seja feito por outrem a ti mesmo ${ }^{649}$.

Tal conclusão não é novidade, pois Hobbes já havia declarado anteriormente que as leis de natureza não são públicas (no sentido de emanadas pela república) e que as leis de natureza não são proclamadas. Também já havia anunciado a suma da lei de natureza em mais de uma oportunidade. O que há de novo é a constatação, agora inescapável, de que há leis obrigatórias não públicas - justamente as leis de natureza. Na seqüência, Hobbes dá o segundo argumento para que a lei seja conhecida como tal:

Em segundo lugar, se for uma lei obrigatória apenas para uma determinada categoria de pessoas,

\footnotetext{
${ }^{648}$ Leviatã, p. 231.

${ }^{649}$ Leviatã, p. 231.
} 
ou de uma determinada pessoa, e não for escrita nem oralmente tornada pública, trata-se igualmente de uma lei de natureza, e é conhecida pelos mesmos argumentos e sinais que distinguem essa categoria dos demais súditos ${ }^{650}$.

Aqui há uma sutil mudança. A lei, diferentemente da anterior situação, não é obrigatória para todos, mas sim para apenas um ou alguns. Do mesmo modo, ela é obrigatória mas não é escrita e nem pública. E é também lei natural. Ou seja, a diferença em relação à lei anterior é apenas a quem ela se dirige (na anterior era a todos, aqui é a alguns). Hobbes explica: "[p]orque toda lei que não seja escrita, ou de alguma maneira publicada por aquele que faz a lei, só pode ser conhecida pela razão daquele que lhe obedece, portanto é uma lei também natural e não apenas civil” ${ }^{\prime 651}$. É uma lei civil também, mas não apenas civil: é lei civil e é lei natural. É uma lei não escrita ou não publicada. É conhecida pela razão de quem obedece (neste caso, como no anterior, difere da lei civil, cuja razão é a de quem coloca a lei, e não de quem a recebe). Se é conhecida pela razão de quem a obedece, é lei natural. Trata-se de outro motivo, tanto quanto a dada no parágrafo anterior, para afirmar que essa tal lei obrigatória e não escrita é lei natural. Para complementar a exposição, Hobbes utiliza um exemplo:

Por exemplo, se o soberano nomear um ministro público sem lhe dar instruções escritas sobre o que deve fazer, o ministro é obrigado a tomar como instruções os ditames da razão. Se nomear um juiz, este deve tomar cuidado para que sua sentença esteja de acordo com a razão do seu soberano e, sendo esta sempre entendida como eqüidade, é obrigatória para ele segundo a lei de natureza. Se nomear um embaixador, este deverá, em todas as

\footnotetext{
${ }^{650}$ Leviatã, p. 231.

${ }^{651}$ Leviatã, p. 231.
} 
coisas que não constarem das suas instruções escritas, tomar como instruções o que a razão lhe ditar como o mais vantajoso para os interesses do soberano, e o mesmo se passa com todos os outros ministros da soberania, públicos e privados. Todas estas instruções da razão natural devem ser compreendidas sob o nome comum de fidelidade, que é um dos ramos da justiça natural ${ }^{652}$.

O ministro é nomeado sem instruções precisas do que deve fazer (fato necessário, pois se as instruções fossem precisas para cada caso concreto não seria necessário um ministro). Essas instruções devem ser tomadas por meio dos ditames da razão. E ditames da razão são justamente leis naturais. Ou seja, o ministro público deve usar a lei natural, não somente a lei civil, para tomar suas decisões. Só que a razão que o ministro público deve usar para tomar sua decisão não pode ser a sua própria, particular, mas sim a razão do soberano. E a razão do soberano, uma vez instituído o poder soberano, é aquela que oficialmente identifica-se com a razão natural. Por isso, a razão do soberano é sempre entendida como eqüidade. A razão do soberano e a razão natural, nesse ponto, coincidem. E, por extensão, acabam coincidindo também a lei de natureza e a lei civil. Essa decisão calcada na razão do soberano via eqüidade "é obrigatória para ele segundo a lei de natureza". O subexemplo do embaixador é a explicitação disso num caso mais concreto. Deve tomar decisões segundo o que a razão lhe ditar. A noção de fidelidade entra como um dos ramos da justiça natural: é uma justiça (adequação da conduta à norma) e é natural (pois se trata de uma lei não escrita, do plano da natureza e não do plano civil). Fidelidade justamente no sentido de ser fiel, de não trair, de não ir contra o estipulado. Nesse ponto, hobbesianamente, traição é sinônimo de injustiça e fidelidade é sinônimo de justiça.

\footnotetext{
${ }^{652}$ Leviatã, p. 231.
} 
Hobbes, insaciável como um macaco faminto, prossegue a análise. Entre as características da lei para ser reconhecida como tal, Hobbes mostra que a confirmação do conteúdo da lei cabe ao juiz autorizado pelo soberano. "Pois, embora a opinião de quem professa o estudo das leis seja útil para evitar litígios, trata-se apenas de uma opinião: é ao juiz que compete dizer aos homens o que é a lei, depois de ter escutado a controvérsia" ${ }^{653}$. Esse juiz irá, em sua sentença, confirmar não só a lei civil, mas também a lei de natureza:

Portanto, se alguém tem um caso de dano fundado na lei de natureza, quer dizer, da eqüidade comum, a sentença do juiz que possui por delegação autoridade para examinar tais causas constitui, nesse caso individual, suficiente confirmação da lei de natureza ${ }^{654}$.

É o juiz que manda, porque representante do soberano. A razão dele torna-se razão pública.

Após dizer em que consiste exatamente a lei e quais as formas de devidamente a identificar, Hobbes trata agora da sua adequada interpretação. Novamente considerações sobre a relação entre lei natural e lei civil. A interpretação da lei reside também na pessoa do soberano:

Se o legislador for conhecido, e se as leis, tanto por escrito como pela luz da natureza, forem suficientemente publicadas, mesmo assim ficará faltando uma circunstância absolutamente essencial para torná-las obrigatórias. Porque a natureza da lei não consiste na letra, mas na intenção ou significado, isto é, na autêntica interpretação da lei

\footnotetext{
${ }^{653}$ Leviatã, p. 233.

${ }^{654}$ Leviatã, p. 233.
} 
(ou seja, do que o legislador quis dizer), portanto a interpretação de todas as leis depende da autoridade soberana, e os intérpretes só podem ser aqueles que o soberano (única pessoa a quem o súdito deve obediência) venha a designar ${ }^{655}$.

Tal medida é necessária para evitar que o intérprete deforme o sentido da lei. Hobbes deu, assim, os caracteres necessários para a obrigação legal: publicação da lei, conhecimento do legislador e autêntica interpretação. A interpretação não é importante para apenas algumas leis: "[t]odas as leis, escritas ou não, têm necessidade de interpretação" ${ }^{656}$. Com isso, Hobbes vê-se obrigado a tratar da interpretação da lei de natureza. Um tema árido, já que ela a princípio reside na razão que é comum a todos os homens, mas que pode variar de homem a homem (resultando em discórdia):

A lei de natureza, que não é escrita, embora seja fácil para aqueles que sem parcialidade ou paixão fazem uso da sua razão natural, deixando portanto sem desculpa os seus violadores, tornou-se agora, por haver poucos, ou talvez ninguém que em alguns casos não se deixe cegar pelo amor de si ou qualquer outra paixão, a mais obscura de todas as leis, e conseqüentemente é a que tem mais necessidade de intérpretes capazes ${ }^{657}$.

A lei de natureza é vista, nesse ponto, como a mais obscura das leis. Daqui vem a necessidade de uma correta interpretação. A lei civil, mesmo que menos obscura, também demanda interpretação ${ }^{658}$. E como são feitas as interpretações das leis? Por meio do juiz que o soberano constitui. Não só da lei civil, mas também da lei natural:

\footnotetext{
${ }^{655}$ Leviatã, p. 234.

${ }^{656}$ Leviatã, p. 234.

${ }^{657}$ Leviatã, p. 234.

${ }^{658}$ Leviatã, p. 235.
} 
A interpretação da lei de natureza é a sentença do juiz constituído pela autoridade soberana, para ouvir e determinar as controvérsias que nela se fundam, e consiste na interpretação da lei ao caso em questão ${ }^{659}$.

E novamente:

sendo portanto a sua sentença uma interpretação da lei de natureza, interpretação essa que não é autêntica por ser a sua sentença pessoal, mas por ser dada pela autoridade do soberano, mediante a qual ela se torna uma sentença do soberano, que então se torna lei para as partes em litígio ${ }^{660}$.

Por meio da interpretação do juiz, a lei natural se faz lei civil. Sai do plano da pura natureza, da razão natural, e entra no plano civil, ganhando concretude e aplicabilidade prática. A lei natural, por outro lado, permanece impávida frente às diferentes interpretações que lhe são colocadas: “[o]s príncipes sucedem-se uns e outros, e um juiz passa e outro vem; mais, o céu e a terra passarão; mas nem um artigo da lei de natureza passará, porque ela é a eterna lei de Deus" ${ }^{\$ 61}$. Não é porque é interpretada e feita lei civil que deixa de ser lei natural.

No caso da interpretação, a lei de natureza é chamada, como no texto de Do cidadão, a completar as lacunas da lei civil.

Porque o sentido literal é aquele que o legislador pretendia que pela letra da lei fosse significado. Ora, supõe-se que a intenção do legislador é sempre a eqüidade, pois seria grande contumélia que um juiz pensasse de maneira diferente do

\footnotetext{
${ }^{659}$ Leviatã, p. 235.

${ }^{660}$ Leviatã, p. 236.

${ }^{661}$ Leviatã, p. 236.
} 
soberano. Portanto ele deve, caso as palavras da lei não autorizem plenamente uma sentença razoável, supri-la com a lei de natureza ou então, se o caso for difícil, suspender o julgamento até receber mais ampla autoridade ${ }^{662}$.

Como ficou bem assentado que ambas as leis equivalem, não é problema aplicar uma na falta da outra.

A identificação entre lei natural e lei civil aparece novamente quando Hobbes dá sua classificação das diferentes espécies de leis:

Concluo portanto que, em tudo o que não seja contrário à lei moral (quer dizer, à lei de natureza), todos os súditos são obrigados a obedecer como lei divina ao que como tal for declarado pelas leis da república. Isso é evidente para a razão de qualquer homem, pois tudo o que não for contrário à lei de natureza pode ser tornado lei em nome dos detentores do poder soberano, e não há razão para que seja menos obrigatório obedecer-lhe quando é proposta em nome de Deus ${ }^{663}$.

Aqui, o autor repete a idéia que a lei civil pode regular tudo, desde que ela não seja contrária à lei de natureza.

A violação das leis também permite a Hobbes tecer certas considerações em relação às leis naturais e civis. Dos três motivos pelos quais o filósofo considera que os homens violam as leis, o segundo aponta para a relação entre lei natural e lei civil:

Em segundo lugar, por falsos mestres, que deturpam a lei de natureza, tornando-a incompatível com a lei civil, ou então ensinam leis

\footnotetext{
${ }^{662}$ Leviatã, pp. 238 e 239.

${ }^{663}$ Leviatã, p. 236.
} 
e doutrinas de sua autoria, ou tradições de tempos anteriores, que são incompatíveis com o dever de um súdito ${ }^{664}$.

De forma que apenas a lei natural deturpada não se coaduna com a lei civil. Lei natural e lei civil são perfeitamente compatíveis quando vistas adequadamente.

O fundamento da lei civil a partir da lei de natureza pode ser visto também na importância da educação para que não haja rebeliões contra o poder soberano:

Antes, os fundamentos desses direitos [do soberano] devem ser ensinados de forma diligente e verdadeira, porque não podem ser mantidos por nenhuma lei civil, ou pelo terror de uma punição legal. Pois uma lei civil que proíba a rebelião (e nisso consiste toda a resistência aos direitos essenciais da soberania) não é (como uma lei civil) nenhuma obrigação, a não ser em virtude da lei de natureza que proíbe a violação do juramento, a qual obrigação natural, se não for conhecida dos homens, impede que eles conheçam o direito de qualquer lei que o soberano faça ${ }^{665}$.

A lei civil, nesse ponto, encontra uma limitação, que pode ser suprida pela educação. A proibição da rebelião é da ordem da lei de natureza, e não da lei civil. Observa-se aqui, outra vez, mais uma situação em que lei natural e lei civil possuem alcance diferente: a questão da proibição da rebelião é assunto não da lei civil, mas apenas da lei de natureza. Seria realmente inútil uma lei civil que dissesse que não pode ser desobedecida. O fundamento último da lei civil está, pode-se ver, na lei natural. A lei civil sozinha não consegue se sustentar. Um positivismo puro é impossível em Hobbes.

\footnotetext{
${ }^{664}$ Leviatã, p. 251.

${ }^{665}$ Leviatã, p. 284.
} 
Ao concluir a terceira parte do livro, sobre a república cristã, Hobbes aponta que

E, porque é um soberano, exige obediência a todas as suas leis, isto é, a todas as leis civis, nas quais estão também contidas todas as leis de natureza, isto é, todas as leis de Deus, pois, além das leis de natureza e das leis da Igreja, que fazem parte da lei civil (pois a Igreja que pode fazer leis é a república), não há nenhuma outra lei divina ${ }^{666}$.

Mais uma vez o filósofo aproxima lei natural de lei civil. As leis naturais, bem como as leis divinas equivalentes, estão contidas nas leis civis. Aqui, Hobbes defende que todas as leis de natureza estão contidas pelas leis civis - afirmação problemática, tendo em vista o fato de certas leis naturais corresponderem apenas à consciência, não podendo haver regulação civil de seu conteúdo.

Há ainda alguns apontamentos sobre a relação entre lei natural e lei civil no Diálogo.

Mais uma vez é a lei de natureza, vista como lei de razão, que enseja a criação do poder comum soberano, que por sua vez irá promulgar as leis a conduzir as ações dos súditos. Dado que os ditames da razão devem visar à melhoria e preservação da vida humana, a lei racional manda que, para que os homens sejam preservados, seja feita necessária a distribuição dos bens, por meio de leis humanas. São as leis civis que garantem a efetividade das leis de natureza:

[é] também um ditame da lei da razão que as leis estatutárias são um meio necessário da segurança e do

${ }^{666}$ Leviatã, p. 284. 
bem-estar do homem no mundo presente, e devem ser obedecidas por todos os súditos, como deve ser obedecido pelo rei e pelos súditos a lei da razão, porque é a lei de Deus $^{667}$.

A similitude entre lei natural, vista enquanto lei da razão, e lei civil é novamente demonstrada quando Hobbes discute por uma segunda vez o caráter racional das leis humanas. Respondendo à afirmação do jurista de que haveria mais de uma espécie de razão, o filósofo conclui que "aquela eqüidade, sobre a qual todos concordam ser a lei da razão, é tudo o que, fora a Bíblia, é ou em algum tempo foi lei na Inglaterra desde que esta se tornou cristã ${ }^{, 668}$. A lei da razão, aqui, é tomada como a mesma coisa que a lei inglesa.

\section{Conclusão}

Com o exposto, algumas questões levantadas ficaram em aberto. Se Hobbes trata da lei de natureza em mais de um sentido, por que ao relacioná-la com a lei civil a usa em apenas um dos sentidos tratados? Da mesma forma a lei civil: por que Hobbes apenas contemplou seu sentido de ordem do soberano ao vinculá-la à lei natural?

Enquanto a lei civil encontra nas obras de Hobbes definições mais firmes e de compreensão mais imediata, a lei natural permanece, em todas as obras de Hobbes, com um caráter ao menos ambíguo.

\footnotetext{
${ }^{667}$ HOBBES, Um diálogo entre um filósofo e um jurista, p. 42.

${ }^{668}$ HOBBES, Um diálogo entre um filósofo e um jurista, p. 47.
} 


\section{Conclusão}

Um ponto que pode ser explorado, e que talvez ajuda a esclarecer tais problemas, é a menção que Hobbes faz, de passagem e apenas algumas vezes, a uma outra lei, que não é nem lei natural e nem lei civil. Estas duas leis, diz Hobbes, seriam não diferentes espécies, mas sim diferentes partes de uma outra lei ${ }^{669}$. Que lei seria essa? Hobbes não diz. Hobbes menciona sua existência, mas não desenvolve nenhuma explicação a respeito de suas características ou atributos. Diz apenas que lei natural e lei civil são partes dessa outra lei. Uma lei maior, a qual ambas estariam submetidas, que lhes daria unidade e consistência. A grande lei, que possui uma parte que é natural e outra que é civil.

Se a lei natural é lei divina, então essa lei maior estaria acima ainda da lei de Deus? Seria ela aquela grande lei universal dos estóicos? Cícero faz referência a essa lei em algumas ocasiões.

Haveria, portanto, uma outra lei na hierarquia, superior mesmo à lei de natureza. Deve ter uma boa explicação. Aqui, Hobbes não conseguiria escapar de algum tipo de transcendência

De acordo com Simone Goyard-Fabre, a identidade entre ambas as leis, o que as coloca como partes de uma terceira lei, está colocada pela razão. "Sua identidade significa sua racionalidade comum" ${ }^{\text {670 }}$. Uma lei maior, uma lei que possui alguma forma de transcendência. Por isso então Hobbes se esforça tanto em escondê-la?

Ao relacionar lei natural e lei civil, vemos que Hobbes apenas relaciona as leis naturais em espécie. Descarta a lei natural em geral. Por que será? Também

\footnotetext{
${ }^{669}$ Leviatã, p. 228.

${ }^{670}$ Simone GOYARD-FABRE, Le droit et la loi dans la philosophie de Thomas Hobbes, p. 182.
} 
utiliza apenas a lei civil como comando do soberano na comparação com a lei natural. Por que não a lei civil como medida das ações do súdito?

A lei natural também pode ser vista de duas formas diferentes. Uma coisa é a lei natural em geral - identificada com a razão. Outra coisa são as leis de natureza em espécie - identificadas com prescrições indicando determinados comportamentos. São coisas diferentes. Mas Hobbes as trata - a ambas - como leis de natureza. A lei natural em geral, dessa maneira, não pode, nunca, ser identificada com lei em sentido próprio - pois razão é cálculo, e não comando. Mas as leis de natureza em espécie podem - pois são prescrições para a ação, e lei é prescrição para a ação. 


\section{Bibliografia}

\section{Obras de Hobbes}

HOBBES, Thomas. Behemoth ou o longo parlamento. Belo Horizonte: Editora UFMG, 2001.

HOBBES, Thomas. Do cidadão. São Paulo: Martins Fontes, 2002.

HOBBES, Thomas. Diálogo entre um filósofo e um jurista. São Paulo: Landy, 2004.

HOBBES, Thomas. Os elementos da lei natural e política. São Paulo: Martins Fontes, no prelo.

HOBBES, Thomas. Os elementos da lei natural e política. São Paulo: Ícone, 2001.

HOBBES, Thomas. The english works of Thomas Hobbes of Malmesbury. 11 volumes. London: Elibron Classics, 2007.

HOBBES, Thomas. Leviatã. Coleção Os pensadores. São Paulo: Nova Cultural, 1996.

HOBBES, Thomas. Leviatã. São Paulo: Martins Fontes, 2005.

HOBBES, Thomas. Leviathan: edited with an introduction by C. B. Macpherson. London: Penguin Books, 1985.

HOBBES, Thomas. Sobre o corpo. Campinas: IFICH/UNICAMP, 2005.

HOBBES, Thomas. Three discourses. Chicago: The University of Chicago Press, 1995.

\section{Obras de comentadores}

ALVES, Marcelo. Leviatã: O demiurgo das paixões: uma introdução ao contrato social hobbesiano. Florianópolis: Unicem Publicações e Ed. Letras Contemporâneas, 2001.

ANGOULVENT, Anne-Laure. Hobbes e a moral política. Campinas: Papirus, 1996.

AUDI, Robert (editor), The Cambridge dictionary of philosophy. Cambridge: Cambridge University Press, 1969.

ARAÚJO, Cícero. As duas definições da lei natural em Hobbes. In: Revista de sociologia e política, N. ㄴ 4/5, 1995, pp. 189 a 198.

BAGBY, Laurie M. Johnson. Hobbes’s Leviathan. London: Continuum, 2007. 
BARBOUW, Jefrrey. Reason as reckoning: Hobbes's natural law as right reason. Hobbes Studies, 21. 2008. pp. 38-62.

BARROS, Alberto Ribeiro Gonçalves de. Direito natural em Cícero e em Tomás de Aquino. In: livro da Atlas [pegar indicação completa]

BELLUSSI, G. Considerazioni sul giusnaturalismo di Thomas Hobbes. In: Thomas Hobbes: Critical assessments. London: Ed. Routledge, 2000.

BERTMAN, M. A. Hobbes on good. In: Thomas Hobbes: Critical assessments. London: Ed. Routledge, 2000.

BERTMAN, Martin A. Hobbes on the character and use of civil law. In: Hobbes oggi: atti del convegno internazionale di studi promosso da Arrigo Pacchi. Milano, Itália: Franco Angeli Libri, 1990.

BIGNOTTO, Newton. Nota metodológica: Guicciardini leitor de Maquiavel. In: Revista discurso, v. 29, 1998, pp. 111 a 131.

BOBBIO, Norberto. Thomas Hobbes. Rio de Janeiro: Campus, 1991.

BOBBIO, Norberto. O terceiro ausente. São Paulo: Manole, 2009.

CAIRNS, Huntington. Hobbes’ theory of law. Seminar jurist, 58. 1946.

CAMPBELL, B. Prescription and description in political thought: the case for Hobbes. In: Thomas Hobbes: Critical assessments. London: Ed. Routledge, 2000.

CARRIVE, Paulette. La conception de la loi chez Hobbes, Bacon et Selden. In: Thomas Hobbes: Philosophie première, théorie de la science et politique. Paris: PUF, 1990.

CHIODI, G.M., Legge naturale e legge positiva nella filosofia politica di Tommaso Hobbes. Milão: Facultà di Giurisprudenzia, 1970.

CROMARTIE, Alan. Unwritten law in Hobbesian political thought. iBritish Jurnal of Politics and International Relatins, Vol. 2, No. 2, June 2000, pp. 161-178.

FRATESCHI, Yara. A física da política: Hobbes contra Aristóteles. Campinas: Editora da Unicamp, 2008.

FRATESCHI, Yara. Estado e direito em Thomas Hobbes. In: Curso de filosofia política: do nascimento da filosofia a Kant. Org.: Ronaldo Porto Macedo. São Paulo: Atlas, 2008. pp. 323-339. [deixar referência de acordo com abnt] 
GAUTHIER, David. Hobbes: the laws of nature. Pacific Philosophical Quarterly, 82. 2001. pp. 258-284.

GERT, Bernard. The law of nature as the moral law. In: Hobbes studies, Vol. 1 - 1988: 26-44.

GOLDSMITH, M. M. Hobbes on law. In: The Cambridge companion to Hobbes, edited by Tom Sorell. Cambridge: Cambridge University Press, 1996. Pp. 274-304.

GOLDSMITH, M. M. Hobbes in law. In: The Cambridge companion to Hobbes, edited by Tom Sorell. Cambridge: Cambridge University Press, 1996.

GOMES, Rita Helena Sousa Ferreira. Lei natural e lei civil em Hobbes. In: revista Educação e filosofia, 19, n. ${ }^{\circ}$ 37, jan/jun. 2005, pp. 143-164

GOTESKY, R. Social sources and the significance of Hobbes's conception of the law of nature. In: Thomas Hobbes: Critical assessments. London: Ed. Routledge, 2000.

GOYARD-FABRE, Simone. Le droit et la loi dans la philosophie de Thomas Hobbes. Paris: Librarie C. Klincksieck, 1975.

GOYARD-FABRE, Simone. Loi civile et obéissance dans L'Etat-Leviathan. In: Thomas Hobbes: Philosophie première, théorie de la science et politique. Paris: PUF, 1990.

GREENLAF, W. H. Hobbes: o problema da interpretação.

GRÓCIO, Hugo. direito da guerra e da paz.

JANINE RIBEIRO, Renato. Ao leitor sem medo: Hobbes escrevendo contra seu tempo. São Paulo: Brasiliense, 1984.

JANINE RIBEIRO, Renato. A marca do Leviatã: linguagem e poder em Hobbes. São Paulo: Editora Ática, 1978.

KING, Preston (ed.). Thomas Hobbes: critical assessments. London: Ed. Routledge, 2000. 4 volumes.

LADENSON, R. In defense of a hobbesian conception of law. In: Thomas Hobbes: Critical assessments. London: Ed. Routledge, 2000.

LAFER, Celso. Hobbes, o direito e o Estado moderno. São Paulo: Associação dos Advogados de São Paulo, 1980.

LIMONGI, Maria Isabel. Hobbes. Rio de Janeiro: Jorge Zahar Editor, 2002. 
LOCKE, John. Dois tratados sobre o governo civil. São Paulo: Martins Fontes, 2004.

MARTINICH, A. P. Hobbes. New York and London: Routledge, 2004.

MARTINICH, A. P. A Hobbes dictionary.

MARTINICH, A. P. Thomas Hobbes in Stuart England. In: A Hobbes dictionary.

MACPHERSON, C. B. A teoria política do individualismo possessivo, de Hobbes a Locke. Rio de Janeiro: Paz e Terra, 1979.

MALHERBE, Michel. Thomas Hobbes. Paris: Librarie Philosophique J. Urin, 1984.

MANFREDI, M. Aspetti formalistici della filosofia giuridica di T. Hobbes. In: Thomas Hobbes: Critical assessments. London: Ed. Routledge, 2000.

MARTINICH, A. P. Hobbes: A biography. Cambridge: Cambridge University Press, 1969.

MESSELMAN, Benjamin J. A razão inconsciente e a suspeita do improvável. São Paulo: edição privada, 1997.

MOORE, S. Hobbes on obligation, moral and political. Part one: moral obligation. In: Thomas Hobbes: Critical assessments. London: Ed. Routledge, 2000.

MOORE, S. Hobbes on obligation, moral and political. Part two: political obligation. In: Thomas Hobbes: Critical assessments. London: Ed. Routledge, 2000.

NEDEL, José. Thomas Hobbes: entre o jusnaturalismo e o positivismo jurídico. Revista Veritas, Porto Alegre, 38 (151): 429-440, set. 1993.

OAKESHOTT, Michael. El racionalismo en la política y otros ensaios. México: Fondo de Cultura Económica, 2000.

OAKESHOTT, Michael. Introducción a 'Leviatán'. In: El racionalismo en la política y otros ensaios. México: Fondo de Cultura Económica, 2000.

OLLERO, A. Hobbes y la interpretacion del derecho. In: Thomas Hobbes: Critical assessments. London: Ed. Routledge, 2000.

PAULSON, Stanley L. Civil law, presumptions, and "right reason" in the philosophy of Hobbes. In: HOBBES TERCENTENARY CONGRESS. S.1. 1979.

PLATÃO. As leis. Bauru: Edipro, 1999. 
POLIN, Raymond. Politique et philosophie chez Thomas Hobbes. Paris: Presses Universitaires de France, 1953.

POGRENBINSCHI, Thamy. O problema da obediência em Thomas Hobbes. Bauru: EDUSC, 2003.

RAPHAEL, D. D. Obligations and rights in Hobbes. In: Thomas Hobbes: Critical assessments. London: Ed. Routledge, 2000.

RIBEIRO, Renato Janine. A marca do Leviatã: linguagem e poder em Hobbes. Cotia: Ateliê editorial, 2003.

RIBEIRO, Renato Janine. Ao leitor sem medo: Hobbes escrevendo contra seu tempo. Belo Horizonte: Ed. UFMG, 1999.

SCHMITT, Carl. The Leviathan in the state theory of Thomas Hobbes: meaning and failure of a political symbol. London: Greenwood Press, 1996.

SKINNER, Quentin. As fundações do pensamento político moderno. São Paulo: Companhia das Letras, 1996.

SKINNER, Quentin. Hobbes e a teoria clássica do riso. São Leopoldo: Editora UNISINOS, 2002.

SKINNER, Quentin. Razão e retórica na filosofia de Hobbes. São Paulo: Fundação Editora da UNESP, 2007.

SKINNER, Quentin. Reason and rethoric in the philosophy of Hobbes. Cambridge: Cambridge University Press, 2004.

SPRINGBORG, Patrícia (ed.). The Cambridge companion to Hobbes's Leviathan. Cambridge: Cambridge University Press, 2007.

STRAUSS, Leo. The political philosophy of Hobbes: Its basis and its genesis. Chicago \& London: The University of Chicago Press: 2007 (a primeira edição, pela The Clarendon Press, Oxford, England, é de 1936).

TAYLOR, A. E. The ethical doctrine of Hobbes. In: Philosophy, vol. 13, N. 52, Oct./1938. pp. 406-424.

TRAINOR, B. T. Hobbes on political allegiance and obligation. In: Thomas Hobbes: Critical assessments. London: Ed. Routledge, 2000. 
TRICAUD, François. Les lois de nature, pivot du système. In: Thomas Hobbes: Philosophie première, théorie de la science et politique. Paris: PUF, 1990.

TUCK, Richard. The 'modern' theory of natural law. In: Languages of politics in early modern Europe. Org: Anthony Pagden. Cambridge: Cambridge University Press, 1969.

TUCK, Richard. Hobbes.

TUCK, Richard. Hobbes. Oxford: Oxford University Press, 2002.

VILANOVA, Marcelo Gross. Lei natural e lei civil na filosofia política de Thomas Hobbes.

WARRENDER, Howard. The political philosophy of Hobbes: his theory of obligation. Oxford: At The Clarendon Press, 1957.

VILLANOVA, Marcelo Gross. Lei natural e lei civil na filosofia política de Thomas Hobbes, 2004. 123. (Tese de mestrado. Universidade Federal do Rio Grande do Sul)

WARRENDER, H. Obligations and rights in Hobbes. In: Thomas Hobbes: Critical assessments. London: Ed. Routledge, 2000.

ZARKA, Charles Yves. Loi naturelle et loi civil chez Thomaz Hobbes. Philosophie. Paris, França, n. ${ }^{\circ} 23$, de 1989, pp. 57 a 79. 